\author{
UNIVERSIDADE DE SÃO PAULO \\ FACULDADE DE FILOSOFIA, LETRAS E CIÊNCIAS HUMANAS \\ PROGRAMA DE PÓS-GRADUAÇÃO EM LÍNGUA HEBRAICA, LITERATURA E \\ CULTURA JUDAICAS
}

\title{
OS AFIXOS NO ENSINO/APRENDIZAGEM DO HEBRAICO LÍNGUA ESTRANGEIRA
}

Álvaro Silva

Monografia apresentada ao Departamento de Pós - Graduação da Faculdade de Filosofia, Letras e Ciências Humanas da Universidade de São Paulo, como trabalho final para a obtenção do título de Mestre em Língua Hebraica, Literatura e Cultura Judaicas.

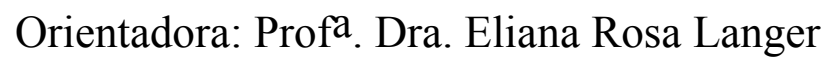

SÃO PAULO - SP

2006 


\section{UNIVERSIDADE DE SÃO PAULO \\ FACULDADE DE FILOSOFIA, LETRAS E CIÊNCIAS HUMANAS \\ PROGRAMA DE PÓS-GRADUAÇÃO EM LÍNGUA HEBRAICA, LITERATURA E CULTURA JUDAICAS}

\section{OS AFIXOS NO ENSINO/APRENDIZAGEM DO HEBRAICO LÍNGUA ESTRANGEIRA}

Álvaro Silva

SÃO PAULO - SP

2006 


\section{DEDICATÓRIA}

À minha esposa Marta e meus filhos: Daniel, Heber e Kátia, pela compreensão e apoio. 


\section{AGRADECIMENTOS}

Primeiramente ao ETERNO, meu Deus, pois tenho certeza que me encaminhou para este aprendizado, uma vez que ELE é o meu foco de interesse.

Para uma reciclagem e ampliação da minha visão e conhecimento de conceitos bíblicos, me apresentei ao Centro de Estudos Judaicos da Universidade de São Paulo com o desejo de solicitar a participação em alguns cursos, como aluno ouvinte. Dado a presteza do departamento, fui esclarecido quanto à possibilidade de uma matrícula oficial e, hoje, o que não era esperado por mim, acontece. Além do bacharelado em Letras/Hebraico, apresento monografia de mestrado, rumo ao título "Mestre". Obrigado, Centro de Estudos Judaicos, por sua disposição e investimento nos interessados em aprender, ensinar e difundir, não só a cultura bíblica, mas toda a cultura que envolve o povo judeu. Sem vocês, eu não teria esta formação e conhecimento, mesmo que ainda me falte muito a conhecer.

Não fora sua partida repentina, poderia dizer-lhe pessoalmente "Muito obrigado, amigo, professor Samuel Hersz Oksman, pelo grande incentivo e inspiração.” (in memoriam)

A todos os professores vinculados ao Centro de Estudos Judaicos, pois estiveram envolvidos direta ou indiretamente no meu aprendizado, faltam palavras para expressar minha gratidão.

Devo agradecer especialmente à professora, Livre Docente, Nancy Rozenchan, pois, durante a minha qualificação, abriu-me novas perspectivas no estudo da língua hebraica e forneceu bibliografia necessária.

Muito mais, à minha orientadora, Dra. Eliana Rosa Langer, pois demonstrou sua perseverança e paciência, instruindo-me, sempre que necessário, para tornar fácil a nossa comunicação no caminho da pesquisa.

A minha primeira idéia de monografia saiu da sala da professora Dra. Maria Aparecida Barboza quando ela ministrava o curso de Lexicologia e não poderia deixar de agradecê-la, mas minha gratidão em especial é à professora Dra. Neide Therezinha Maia Gonzalez, cuja 
participação marca a pesquisa desde quando a idéia nasceu e, portanto, não pode ser definida apenas por seus títulos e nomeações, mas sim com uma palavra: amiga. Muito obrigado. 


\section{RESUMO}

Uma das características da língua hebraica, bem como das demais línguas semíticas, é sua construção a partir de uma raiz formada, em geral, por três consoantes principais. Para formar seus textos, serão aglutinadas a estas raízes consoantes afixas (prefixos/infixos/ sufixos $)^{1}$, com funções de pronomes, preposições, e outras.

$\mathrm{Na}$ tentativa de alcançar satisfatoriamente nosso objetivo, o ensino do hebraico língua estrangeira, propomos a utilização de uma metodologia de ensino que facilite a memorização, a busca do sentido contextualizado e o ensino de estruturas gramaticais com o mínimo de conteúdo léxico, preparando o aprendiz para conquistá-lo em tempo oportuno.

Uma das possibilidades de facilitação do ensino do léxico hebraico pode ser observada nas características desta língua, quando baseada na estrutura formal dos pronomes pessoais e alguns elementos inseridos em diversas categorias gramaticais, que nela aparecem como afixos. Esses afixos hebraicos são elementos que dão conta do direcionamento textual bem como de quase todas as ações e temporalidades verbais.

A função artigo $^{2}$ exercida por estas consoantes será o fio condutor do nosso objetivo em demonstrar a permeabilidade da língua e estimular professores e pesquisadores na busca de elementos que facilitem o aprendizado ao utilizarem os afixos como ponto de partida para o entendimento do texto hebraico, especificamente o bíblico, como língua instrumental.

\section{Palavras-Chave: Hebraico - Afixo - Forma - Coesão - Aprendizagem.}

\footnotetext{
${ }^{1}$ Os infixos não serão contemplados nesta pesquisa, porque não favorecem o seu objetivo.

${ }^{2}$ A função artigo ocorre quando um termo passa a pertencer ao paradigma articular funcionalmente definido (Koch, 1991:34).
} 


\begin{abstract}
One of the characteristic of Hebraic language, just like other semitic languages, is its construction from a structure composed, in general, for three main consonants. To obtain their texts there will be agglutinated affix consonants (suffix/prefix) in these radicals with functions of pronouns, prepositions, among others.
\end{abstract}

Trying to get satisfactionally our objective, which is teaching of Hebraic language, we propose a method of teaching that makes easier the process of memorizing, looking for a context that make sense and the teach of grammatical structures that have the minimum of lexicon content, preparing the learner to make the most of the Hebraic language.

One of the possibilities of making easier the lexicon Hebraic teaching can be observed in the characteristic of this language, based in formal structure of personal pronouns and some elements introduced in other grammatical categories, which are affixes. These Hebraic affixes are elements that give textual direction of almost all actions and verbal temporality.

The article function used by these consonants will be the guide of our objective in order to show the permeability of this language and stimulate teachers and scientists to search elements that become easier the learning using affixes as beginning to understand the Hebraic text, mainly the biblical one, as instrumental language.

Key Words: Hebrew - Affix - Form - Coesion - Learning. 


\section{ÍNDICE DAS FIGURAS}

Figura 1 Quadro de Flexão Pronominal do Verbo Hebraico

pág. 09

Figura 2 Quadro dos Pronomes Oblíquo e Possessivo do Português e do Hebraico Masculino

pág. 10

Figura 3 Quadro Contrastivo dos Pronomes Sufixo do Hebraico com o Português pág. 46

Figura 4 Quadro de Flexão Pronominal do Verbo Concluso Hebraico

pág. 48

Figura 5 Quadro de Flexão Pronominal do Verbo Inconcluso Hebraico

pág. 52

Figura 6 Quadro Contrastivo dos Pronomes Sufixo e Pessoal do Hebraico com o Português

pág. 64

Figura 7 Quadro de Recurso Mnemônico Para os Pronomes Hebraico

pág. 83

Figura 8 Quadro de Sufixos Nominais do Hebraico

pág. 84

Figura 9 Quadro de Recurso Mnemônico Para os Pronomes Prefixos do Hebraico pág. 85

Figura 10 Quadro de Recurso Mnemônico Para os Prefixos Nominais do Hebraico pág. 86

Figura 11 Quadro Contrastivo Geral dos Afixos Hebraicos

pág. 87 


\section{TRANSLITERAÇÃO FONÉTICA UTILIZADA NA PESQUISA}

As palavras e os nomes de origem hebraica, apresentadas transliteradas na pesquisa, acompanharão a transliteração fonética segundo Rifka Berenzin, in Dicionário HebraicoPortuguês - EDUSP, São Paulo, 1995.

$\rightarrow \quad \Omega \quad=$ não apresenta correspondente para transliteração fonética, assume a representação vocálica.

$\mathrm{B}=\mathrm{b}$

$\mathrm{b}=\mathrm{v}$

$\mathrm{G}=\mathrm{g}$ (em gado ou gu em gueto)

$\mathrm{g}=\mathrm{g}$ (em gado ou gu em gueto)

$\mathrm{D}=\mathrm{d}$

$\mathrm{d}=\mathrm{d}$

$\Pi$ = será representado por " $\mathrm{h}$ " (lido leve aspirado como o h do inglês), no início e no meio das palavras, no final não é representado, nem sonoro.

$\mathrm{W}=\mathrm{W}$

$\mathrm{Z}=\mathrm{Z}$

— = Será representado por " $\mathrm{h}$ "(lido forte aspirado como o $\mathrm{j}$ do espanhol) no início das palavras e " kh " (lido forte aspirado como o j do espanhol) no meio e final das palavras.

$\mathrm{j}=\mathrm{t}$

$\mathrm{y}=\mathrm{y}$

৫) $\rightarrow \&=\mathrm{k}$

$\boldsymbol{N} \nabla=$ kh (lido fortemente aspirado como o j do espanhol).

$1=1$

$\mathrm{m}=\mathrm{m}$

$\mathrm{n}=\mathrm{n}$

$\mathrm{P}=\mathrm{p}$

$\mathrm{p}=\mathrm{F}$

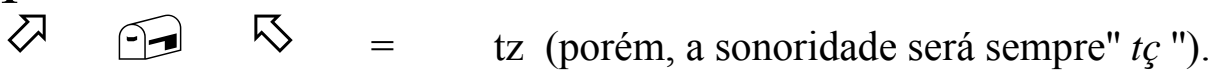




$$
\begin{array}{llll}
\mathrm{r} & = & \mathrm{r} \\
\mathrm{V} & = & & \\
\mathrm{f} & \rightarrow & \mathrm{S} & \\
\mathrm{T} & = & \mathrm{t} & \\
\mathrm{t} & = & \mathrm{t}
\end{array}
$$




\section{ÍNDICE}

1. INTRODUÇÃO 01

1.1. Justificativa da Pesquisa $\quad 01$

1.2. Objetivos da Pesquisa 04

1.3. Metodologia Aplicada 06

2. BREVE HISTÓRICO DA LÍNGUA HEBRAICA 12

2.1. Escrita Consonantal 30

3. BASE GRAMATICAL NA COESÃO SUFIXADA DO TEXTO HEBRAICO 32

3.1. Estabelecendo o Que e Como Pesquisar na Gramática 32

3.2.Os Pronomes Pessoais 38

3.2.1. Pronomes Pessoais do Caso Reto 38

3.2.1.1. Para a Primeira Pessoa eu e nós 38

3.2.1.2. Para a Segunda Pessoa tu e vós 38

3.2.1.3. Para a Terceira Pessoa ele(a) e eles(as) 39

3.2.2. Pronomes Pessoais do Caso Oblíquo - Sufixos Hebraicos 40

3.2.2.1. Pronomes Pessoais do Caso Oblíquo Átonos 40

3.2.2.1.1. Para a Primeira Pessoa. me e nos 40

3.2.2.1.2. Para a Segunda Pessoa te e vos 40

3.2.2.1.3. Para a Terceira Pessoa o/a/se/lhe/(s) 41

3.2.2.2. Pronomes Pessoais do Caso Oblíquo Tônicos 42

3.2.2.2.1. Para a Primeira Pessoa mim e nós 42

3.2.2.2.2. Para a Segunda Pessoa ti e vós 42

3.2.2.2.3. Para a Terceira Pessoa ele/ela/(s)/si 43

3.3. Os Pronomes Possessivos - Sufixos Hebraicos 44

3.3.1. Primeira Pessoa meu(s)/minha(s)/nosso(s)nossa(s) 44

3.3.2. Para Segunda Pessoa teu(s)/tua(s)/vosso(s)/vossa(s) 44

3.3.3. Para a Terceira Pessoa seu(s)/sua(s) 45

3.4. Os Pronomes Prefixos Hebraicos 52

3.5. Os Afixos Como Elementos de Coesão Textual 57 
3.5.1. Forma Remissiva Não Referencial Presa (Função Artigo) 60

3.5.1a Artigos Definidos e Indefinidos $\quad 60$

3.5.1b Pronomes Adjetivos $\quad 62$

3.5.1b1 Pronomes Adjetivos Demonstrativos 62

3.5.1b2 Pronomes Adjetivos Possessivos 63

3.5.1b3 Pronomes Adjetivos Indefinidos 66

3.5.1b4 Pronomes Adjetivos Interrogativos 66

3.5.1b5 Pronome Adjetivo Relativo 66

3.5.1c Os Numerais (Cardinais e Ordinais) 67

3.5.2. Forma Remissiva Não Referencial Livre 67

3.5.2.1. Os Pronomes Pessoais de Terceira Pessoa: ele/s, ela/s 67

3.5.2.2. Pronomes Substantivos 68

3.5.2.2.a Pronomes Substantivos Possessivos 68

3.5.2.2.b Pronomes Substantivos Interrogativos e Relativos 69

3.5.2.3. Os Numerais $\quad 69$

4. O ENSINO DO HEBRAICO LÍNGUA ESTRANGEIRA A PARTIR DOS AFIXOS $\begin{array}{ll}\text { FOCO NA FORMA } & 71\end{array}$

4.1. Apresentação de um Modelo Prático de Análise 75

4.2. Uma Didática Para o Aprendizado dos Sufixos Hebraicos 82

4.3. Uma Didática Para o Aprendizado dos Prefixos Hebraicos 85

4.3.1. Tabela de Recursos Mnemônicos Para os Pronomes Prefixos do Hebraico 85

$\begin{array}{ll}\text { 4.3.1.1. Masculino } & 85\end{array}$

4.3.1.2. Feminino 85

4.3.2. Tabela de Recursos Mnemônicos Para os Prefixos Nominais 86

4.3.3. Sistematizando o Quadro Contrastivo dos Afixos Hebraico 86

4.4. Relato de Aplicação da Proposta de Ensino - O Caso Marlene 89

5. CONCLUSÃO 90

6. BIBLIOGRAFIA 92 


\section{INTRODUÇÃO}

\subsection{Justificativa da Pesquisa}

Trilhando o caminho do ensino das letras hebraicas é comum esbarrarmos na afirmação: "o hebraico é uma língua de difícil aprendizado". Também é possível notar que muitos professores da área concordam com ela, então, resolvemos questionar essa idéia através da analise da fonte desta afirmação.

Surgindo a afirmação "o hebraico é uma língua de difícil aprendizado", imediatamente devemos observar sua fonte, ou seja, quem afirma. Se estivermos atentos perceberemos duas classes distintas: o leigo (incluso aprendizes iniciantes) e o conhecedor superficial (inclusive o professor não-pesquisador).

Do ponto de vista do leigo não é possível formular teoria, uma vez que estará falando apenas do visual ou audível, momentâneo, e, quando não, estará expressando palavras sem ter pensado sobre o que está afirmando, pois muitas vezes o faz sem o mínimo contato com a língua. Por outro lado, o aprendiz, ao tomar contato com a língua, irá, sem dúvida, estranhar muito, e isso porque sua mente não está preparada para visualizar os símbolos hebraicos como escrita (estamos falando de aprendizes que não conhecem a escrita hebraica). Em princípio, ocorrerá o impacto com a forma escrita, depois seu direcionamento da direita para esquerda, contrário às escritas ocidentais. Porém, transpostas tais barreiras, poderão ser alfabetizados e preparados para se encontrarem com a gramática hebraica e seus elementos textuais.

Não será incomum, após uma boa alfabetização e um trabalho de "desmitificação", que o aprendiz mude de opinião e passe a afirmar que o hebraico é fácil ou, pelo menos, não tão difícil como parecia e, portanto, o aprendizado vencerá sozinho a força mítica restante.

A dificuldade pode estar nesta afirmação, quando proferida por conhecedores superficiais do hebraico.

Além disso, a pesquisa nos colocará em contato com elementos da Lingüística 
Descritiva, propiciando, de certa forma, um acréscimo na nossa visão dentro do sistema de aquisição de uma língua estrangeira, baseado primeiramente nos trabalhos Understanding Second Language Acquisition, 1985, de R. Ellis, e Principles of Language Learning and Teaching, 1994, de H.D.Brown, uma vez que a pretensão final do trabalho é propor um método que facilite o ensino/aprendizagem do Hebraico.

Do ponto de vista da pesquisa propriamente dita, podemos observar inicialmente que os autores de gramáticas, embora apresentem de forma sistemática os prefixos e sufixos, o fazem separadamente, sem visão de conjunto, como podemos perceber na: Gramática Elementar do Hebraico Bíblico, de Hollenberg - Budde, 1962 (traduzida por Nelson Kirst em 1991) e Hebraico Bíblico - Uma Gramática Introdutória, de Page H. Kelley (1998). Esta disposição estimula a apreensão mecânica, conforme tenho percebido na prática, em sala de aula, o que não promove a facilitação do entendimento e assimilação destes afixos.

$$
\begin{aligned}
& \text { Estudando os exemplos: hwhyl yt } \underline{\underline{r b d}}=\text { Eu disse para Adonai } \\
& \text { hwhy ynrbd = Disse-me Adonai } \\
& \text { hwhyl yrbd }=\text { Minha palavra para Adonai }
\end{aligned}
$$

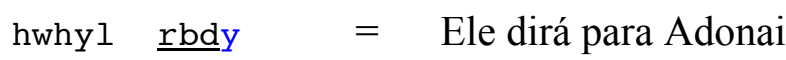

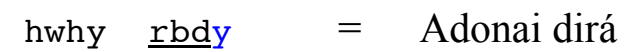

$$
\begin{aligned}
& \text { hwhy } \underline{\mathrm{rbdk}}=\text { Como a palavra de Adonai }
\end{aligned}
$$

1 - observamos a mesma raiz rbd em todas as frases com funções gramaticais diferentes (verbo em todos os exemplos, excetuando y $\underline{r b d}$ no terceiro exemplo e $\underline{\mathrm{rbdk}}$ no último exemplo, nos quais a raiz funciona como substantivo);

2 - observamos os sufixos yt, yn, y, cuja regularidade mostra o y como indicador de primeira pessoa em todos os casos;

3 - observamos o mesmo y como prefixo, indicando terceira pessoa;

4 - observamos ainda os prefixos nominais $\mathrm{k}=$ conjunção "como" e $1=$ preposição "para" que serão discutidos no corpo da pesquisa.

Baseando-se nessas observações, é possível formular duas importantes considerações: em primeiro lugar, podemos admitir que o y , em virtude da sua repetida ocorrência como sufixo de primeira pessoa, alcança maior probabilidade de interiorização, porque terá seu 
significado associado aos significantes que já constam no arquivo mental do aprendiz, além de estar associado ao seu visual gráfico e, assim, sua interiorização não deverá acontecer pelo ato de decorar textos. Em segundo lugar, fica clara a idéia de direcionamento do texto, visto que essas partículas se apresentam nos textos como elementos da língua, cuja função precípua é estabelecer relações textuais, conforme se observa em A Coesão Textual de Ingdore G.V. Koch (1991) denominando-os "recursos de coesão textual". Tal direcionamento se justifica através do resultado obtido quando o afixo é acrescentado à raiz, pois modifica/orienta o sentido do texto, fortalecendo assim o ponto de vista da pesquisa, cujo foco será mantido nos afixos da Língua Hebraica Bíblica como elementos de coesão textual.

Os estudos da sintaxe do hebraico bíblico desenvolveram-se proporcionando um bom entendimento do texto, fundamentando assim a exegese do antigo testamento, no entanto, as consoantes afixas ainda podem ser estudadas como elementos de coesão de texto, cuja importância nos conduz a pensar na seguinte questão: Afinal, o que são os afixos da língua hebraica bíblica?

Uma vez conhecidos os afixos (prefixos e sufixos) hebraicos e seu papel na escrita, já que estamos tratando do elemento visual aparente quando olhamos para um texto escrito, seria possível mediar sua compreensão e o seu aprendizado a partir da elaboração de uma "tabela de afixos". 


\subsection{Objetivos da Pesquisa}

Esta seção da monografia pretende apresentar os objetivos da pesquisa e, neste caso, entendemos ser melhor antes da apresentação dos mesmos, esclarecer o que não é nosso objetivo. Não objetivamos apresentar uma nova metodologia de ensino do hebraico língua estrangeira, nem tampouco esgotar as possibilidades gramaticais ou mapear o comportamento da sintaxe do hebraico, muito menos esgotar suas possibilidades lexicais no seu campo semântico.

A pesquisa pretende, inicialmente, demonstrar que o hebraico não é língua de difícil aprendizado, sendo assim, incorpora-se a este objetivo a apresentação de um ponto de partida para os iniciantes nos estudos de leitura e tradução limitados ao campo visual de um aprendiz brasileiro.

Um bom começo seria a pesquisa demonstrar que as partículas afixas, existentes em número bem limitado, constituem elementos importantes para a coesão textual da língua hebraica. Sabemos que elas se apresentam como elementos capazes de dar conta do direcionamento de quase todas as ações verbais como pronomes afixos, além de funcionarem como pronomes oblíquos e pronomes possessivos, o que aponta para a possibilidade de facilitar aos estudantes brasileiros adquirirem conhecimento destes pronomes, relacionando-os com o conhecimento do léxico dos pronomes da língua portuguesa. Neste caso, podemos também incorporar a esse objetivo nossa disposição em demonstrá-los como um ponto de partida para o entendimento do texto hebraico.

Uma vez que as partículas afixas são em número limitado e apresentam possibilidade de formar a conexão textual do hebraico, cuja tradução pode corresponder a elementos significativos responsáveis pela construção da linearidade textual da língua portuguesa, uma tabela contrastiva seria uma ferramenta de grande ajuda na tradução de textos e, conseqüentemente, no aprendizado como língua instrumental, visto que tais elementos visuais comparativos auxiliam a leitura e compreensão do texto hebraico. Assim, é também nosso objetivo apresentar um estudo comparativo destes pronomes, confirmando tais possibilidades e, a partir delas, apresentar uma tabela contrastiva destes afixos. 
Objetiva também, conforme interesse pessoal do pesquisador, professor desta área, a tentativa de apresentar um tema que possibilite a facilitação do aprendizado da língua, a fim de estimular outros professores/pesquisadores, bem como nossos alunos.

Uma vez, estabelecido os afixos como ponto de partida para o entendimento do texto hebraico, provavelmente estaremos facilitando a aquisição da língua hebraica como língua estrangeira. Assim sendo, a somatória desses objetivos pode ser reduzida na seguinte afirmação: O conhecimento dos afixos do hebraico como elemento de coesão textual facilita seu aprendizado como língua estrangeira.

Se os elementos de coesão textual são utilizados para construir o texto, o conhecimento de alguns significados poderá facilitar ao aprendiz intuir o contexto. Assim, a pesquisa pretende verificar se a aquisição do léxico pode ser alcançada a partir destes elementos de construção de texto. 


\subsection{Metodologia Aplicada}

Quando tratamos de uma língua estrangeira, mesmo que seja instrumental, não podemos simplesmente impor uma fórmula de aprendizado fundada no ato de decorar textos ou palavras, pois o aprendizado exige muitos outros comportamentos. Por isso, estamos propondo este aprendizado a partir de sua construção textual, observando sua estrutura lingüística e estudando sua gramática não como um conjunto de regras, mas sim como um elemento funcional do texto que possibilite o bom desempenho na sua compreensão. $\mathrm{Na}$ língua/escrita proposta optamos pela utilização do texto da Bíblia Hebraica Stuttgartensia, sustentando nossas afirmações nas gramáticas elementares apresentadas na bibliografia.

Com base no aparato teórico obtido da leitura dos livros constantes da bibliografia, cuja finalidade é direcionar o aprendizado ou a aquisição de uma língua estrangeira, serão apresentados, depois de extraídos por métodos investigativos, os valores das referidas partículas afixas observados na função artigo por elas exercidas como elementos de coesão textual.

A pesquisa está situada na área da lingüística descritiva, mais propriamente lingüística textual, e terá como fio condutor da análise a coesão textual do hebraico bíblico baseada nos estudos lingüísticos de aquisição da linguagem, aproximando-nos a uma língua completamente diferente das línguas latinas, cujos afixos serão pontos de vantagem na aquisição do Hebraico, tanto quanto o são os cognatos que se observam nas línguas latinas.

Depois de confirmadas suas implicações lingüísticas, conforme mencionamos acima, apresentaremos estes afixos estudando suas manifestações diretamente nos textos bíblicos para que possam ser observados como elementos de coesão textual, tomando como ponto de partida uma tabela contrastiva para simplificação do trabalho a ser criada especificamente com a finalidade de tradução.

Em resumo, seus resultados serão obtidos conforme os seguintes procedimentos:

$1^{\mathrm{O}} \quad$ Análise das partículas afixas segundo sua função artigo para enquadramento como um elemento de coesão textual. 
$2^{0} \quad$ Análise da implicação destes elementos no aprendizado/aquisição do hebraico como língua estrangeira e instrumental.

$3^{0} \quad$ Sistematização desses elementos em uma tabela para visualização de conjunto.

$4^{0} \quad$ Comprovação textual da aplicabilidade destes elementos ao texto bíblico.

Os resultados obtidos através destes procedimentos quando confrontados com opiniões de outros autores (apresentados na bibliografia), mesmo que tenham obedecido a procedimentos diversos, deverão demonstrar, ou não, sua aplicabilidade, além de mostrar claramente a obediência às suas teorias nela apresentadas.

Fixamos nosso corpus de análise no léxico dos afixos hebraicos observando seus correspondentes na língua portuguesa (do Brasil), destacando-se os pronomes pessoais e possessivos desta língua conforme apresentados em dicionários de verbetes, além de outros elementos que venham compor sua superfície textual.

Para atingir o objetivo da pesquisa, procuramos encontrar na língua hebraica uma parte formal permanente, na tentativa de desfazermos o pressuposto: o hebraico é língua de "difícil" aprendizado, utilizando a obra de Chaim Rabin: Pequena História da Língua Hebraica ${ }^{1}$ e a obra: O Hebraico: 3000 Anos de História, escrito por Mireille Hadas-Lebel ${ }^{2}$, que permitem entender o hebraico como língua única, cujo ponto de partida é a escrita bíblica, fornecedora da base morfológica e sintática que conduzirá o hebraico até os dias atuais (modernizado) para desfazer a idéia de sua dificuldade apoiada na visão de "três hebraicos distintos", o bíblico, o mischnaico e o moderno.

Acreditando no hebraico como língua única o passo seguinte seria estabelecer um caminho para seu aprendizado. André Martinet, em Função e Dinâmica das Línguas ${ }^{3}$, já tratava da aquisição da língua hebraica como língua estrangeira pela observação de sua característica como língua consonantal, podendo servir de base inicial. Uma vez que apoiaremos a pesquisa na morfologia e sintaxe do hebraico, porque permaneceram como base

\footnotetext{
${ }^{1}$ Tradução Rifka Berenzin. São Paulo, Summus Editorial, 1973.

${ }^{2}$ Tradução Eliana Branco Malanga. São Paulo, Centro de Estudos Judaicos FFLCH USP, 1998.

${ }^{3}$ Tradução Jorge de Moraes Barbosa e Maria Joana Vieira Santos. Coimbra (Portugal), Livraria Almedina, 1995.
} 
fixa durante sua evolução como língua viva, recorreremos à obra: Teoria Lexical ${ }^{1}$. Contudo, certamente restringiremos nosso campo de ação, visto estarmos diante de um ramo que congrega infinitas possibilidades. Assim buscaremos uma possibilidade na lingüística textual de C. V. M. Sitya (1995) em sua obra: A lingüística textual e a análise do discurso: uma abordagem interdisciplinar ${ }^{2}$. Este caminho apontou para os afixos hebraicos como elementos de coesão textual, cuja teoria Ingdore Vilaça Koch desenvolve em sua obra A Coesão textual. ${ }^{3}$

Será focalizada também a correspondência destes elementos na gramática da língua portuguesa com seus correspondentes hebraicos fornecidos por um corpus referencial, cujos pronomes pessoais e possessivos se observaram em Pasquale Cipro Neto \& Ulisses Infante na Gramática da Língua Portuguesa ${ }^{4}$ e seus verbetes traduzidos de acordo com a obra de Jaffa Rifka Berenzin, o Dicionário Hebraico-Português ${ }^{5}$, cujos valores pronominais foram confirmados por Johannes Hollenberg e Karl Budde na Gramática Elementar da Língua Hebraica $^{6}$, bem como por P. Joüan e T. Muraoka em A grammar of biblical hebrew ${ }^{7}$.

O objetivo desta pesquisa realiza-se no momento em que deixamos a coesão textual e/ ou alteração de significados promovida pela sonoridade vocálica em segundo plano para manter em foco o seu comportamento consonantal, visto que a escrita hebraica utiliza como ponto de partida uma raiz (constituída por três consoantes em sua grande maioria) que receberá afixos (prefixos, infixos ou sufixos), formados por algumas consoantes que desempenham diversas funções tais como: preposição, pronome etc.

Usando como exemplo a raiz verbal rbd (dbr), representando a base consonantal que, no texto, receberia a afixação responsável pela orientação (direcionamento), observamos:

a - Por exemplo, no verbo conjugado, expresso na tabela abaixo:

\footnotetext{
${ }^{1}$ BASÍLIO, M. Teoria Lexical :série princípios, $2^{\text {a. }}$ ed. São Paulo: Ática, 1.989.

${ }^{2}$ Dados bibliográficos completos, consultar a bibliografia, p. 90.

${ }^{3} 4^{a}$ ' ed. São Paulo: Contexto, 1991.

${ }^{4}$ São Paulo: Scipione, 1997.

${ }^{5}$ São Paulo: Edusp, 1995.

${ }^{6}$ Tradução Nelson Kirst. $7^{\text {a }}$ ed. São Leopoldo(R.S.): Sinodal, 1991.

${ }^{7}$ Roma, P.I.B., 1993.
} 
Tabela 1 Quadro de Flexão Pronominal do Verbo Hebraico

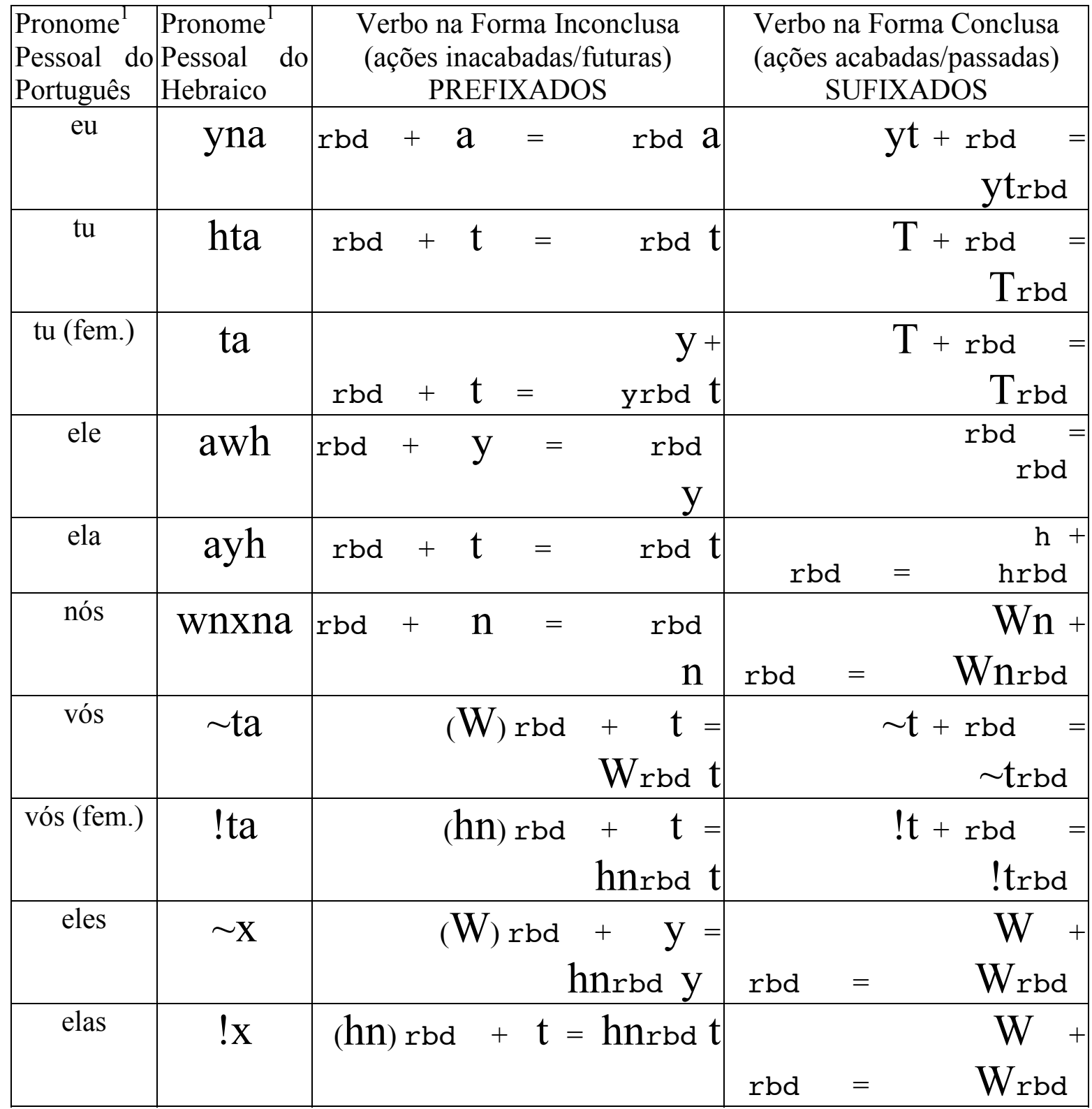

a consoante " y " (y), última letra do pronome yna (ani)= eu, formando ytrbd (dbrty, lida como dibarty $=$ eu falei $)^{2}$, apesar de receber uma consoante " $t "(t)$ entre o radical e o sufixo será a marca da primeira pessoa do verbo representante das ações conclusas (passadas) em todos os verbos. Esta mesma consoante " y "(y) forma a palavra rbdy ( $y d b r$, lida como

\footnotetext{
${ }^{1}$ Estes são os pronomes do caso reto.

${ }^{2}$ Observe que o verbo bíblico expressa a ação e a pessoa pronominal quando esta se apresenta afixada, mas deixa a temporalidade por conta de outros elementos da frase, portanto sua tradução/conjugação dependerá desses outros elementos.
} 
yedaber = ele falará) e, neste caso, em oposição ao verbo sufixado, marcará a terceira pessoa do discurso, além de representar, em virtude da sua posição como prefixo, as formas verbais inconclusas (futuras) em todos os verbos.

Semelhante ao pronome da primeira pessoa, as demais pessoas se apresentarão como afixos nas raízes, em uma forma extremamente resumida, para expressar a conjugação dos verbos conclusos (forma sufixada) e inconclusos (forma prefixada), ao mesmo tempo que desempenham a função de pronomes.

b - Por exemplo, na forma masculina pronominal, expressa na tabela ${ }^{1}$ abaixo:

Tabela 2 Quadro dos Pronomes Oblíquos e Possessivos do Hebraico Masculino com o Português

\begin{tabular}{|c|c|c|c|c|c|c|c|}
\hline \multicolumn{8}{|c|}{ PRONOMES } \\
\hline \multicolumn{5}{|c|}{ PESSOAIS $^{2}$} & \multicolumn{3}{|c|}{ POSSESSIVOS $^{3}$} \\
\hline \multicolumn{2}{|c|}{ PORTUGUÊS } & \multicolumn{3}{|c|}{ HEBRAICO } & \multirow{3}{*}{ PORTUGUÊS } & \multirow{3}{*}{$\begin{array}{l}\text { HEBRAICO } \\
\text { (SUFIXOS) }\end{array}$} & \multirow{3}{*}{$\begin{array}{c}\text { RAÍZ } \\
\text { rbd } \\
+ \\
\text { SUFIXOS }\end{array}$} \\
\hline \multicolumn{2}{|c|}{ Caso Oblíquo } & \multicolumn{2}{|c|}{$\begin{array}{l}\text { Caso Oblíquo } \\
\text { (SUFIXOS) }\end{array}$} & \multirow{2}{*}{$\begin{array}{c}\text { RAIZ rbd } \\
+ \\
\text { SUFIXOS }\end{array}$} & & & \\
\hline Átono & Tônico & Átono & Tônico & & & & \\
\hline me & $\operatorname{mim}$ & yn & yn & ynrbd & $\operatorname{meu}(\mathrm{s}) / \operatorname{minha}\left(\mathrm{s}^{4}\right)$ & $\mathrm{y}$ & Yrbd \\
\hline te & ti & $\wedge$ & $\wedge$ & $\wedge_{\text {rbd }}$ & teu & $\wedge$ & $\wedge_{\text {rbd }}$ \\
\hline o/se/lhe & ele/si & wh & wh & whrbd & seu/dele & W & Wrbd \\
\hline nos & nós & wn & wn & Wnrbd & nosso/nossa & Wn & Wnrbd \\
\hline vos & vós & $\sim \mathrm{k}$ & $\sim \mathrm{k}$ & $\sim \mathrm{Krbd}$ & vosso & $\sim \mathrm{k}$ & $\sim \mathrm{krbd}$ \\
\hline os/se/lhes & eles/si & $\sim \mathrm{h}$ & $\sim \mathrm{h}$ & $\sim$ hrbd & seu/dele & $\sim \mathrm{h}$ & $\sim$ hrbd \\
\hline
\end{tabular}

\footnotetext{
${ }^{1}$ Vale lembrar que a sonoridade vocálica produz alterações de significado e deveria ser apresentada na tabela, mas a pesquisa contempla apenas as formas consonantais.

${ }^{2}$ No hebraico, os pronomes oblíquos quando sufixos assim como no Português aparecem com o verbo.

${ }^{3}$ No hebraico, os pronomes possessivos quando sufixos assim como no Português aparecem com o nome.

${ }^{4}$ Demais plurais formam-se com o infixo y acrescido antes do sufixo. Ex: ${ }^{\wedge}$ yrbd tua(s) palavras.
} 
Podemos observar os sufixos hebraicos nas suas funções pronominais tanto no caso oblíquo, como no possessivo. Na língua portuguesa, os pronomes oblíquos aparecem nas formas átonas e tônicas. Todas as pessoas pronominais são representadas por uma palavra distinta para cada um destes tipos de pronomes, inclusive os possessivos. Já no hebraico, os pronomes oblíquos apresentam dupla função: podem ser utilizados como átonos ou tônicos. Os possessivos são praticamente iguais aos oblíquos diferindo apenas a primeira e terceira pessoa do singular, que utilizam só a última consoante do sufixo para formar o possessivo.

Como a raiz rbd oferece duas possibilidades de categorias gramaticais ${ }^{1}$ (o mesmo ocorre com quase todas as raízes hebraicas), podendo ser um verbo ou então um nome, o tipo de pronome se relacionará com a categoria gramatical da raiz sufixada por ele:

1 - se for verbo receberá o sufixo yn formando a palavra ynrbd (dbrny, lida como dibrany $=$ ele falou-me) e o pronome será equivalente ao oblíquo ${ }^{1}$ da língua portuguesa.

2 - se for substantivo receberá o sufixo y formando a palavra yrbd(dvry, lida como $d v a r i=$ minha palavra / meu dito / minha fala) e o pronome será possessivo.

Porém, em qualquer um dos casos o sufixo " y " indica que as palavras com essa terminação, tanto verbos como nomes, devem ser remetidas à "primeira pessoa do singular".

Além desses exemplos, poderíamos apresentar algumas preposições que recebem os mesmos sufixos pronominais, fortalecendo a nossa teoria, mas acreditamos que os exemplos apresentados sejam suficientes para propor os sufixos pronominais, bem como os prefixos verbais (descritos na tabela do exemplo "a") e mais uns poucos prefixos que serão apresentados no corpo da pesquisa como a base capaz de simplificar os primeiros passos no aprendizado da língua hebraica.

\footnotetext{
${ }^{1}$ É lógico que concorre com estas categorias sua variação semântica e, neste caso, somos dependentes do contexto para obtermos sua tradução, assim, trabalhamos com a hipótese do sema igual ao verbo falar ou o substantivo palavra.
} 


\section{BREVE HISTÓRICO DA LÍNGUA HEBRAICA}

A questão "O Hebraico é Uma Língua de Difícil Aprendizado" aparentemente se apóia na idéia de que "para entendermos o hebraico, precisaremos primeiro saber de qual hebraico se trata: do bíblico, talmúdico ou moderno". Se estivermos diante de três línguas hebraicas ou três tipos de hebraicos distintos, como se acreditava no século passado, será muito difícil responder a essa questão, porém, se existirem elementos básicos idênticos que identifiquem os supostos "três hebraicos" como um só, ou seja, se existirem elementos comuns nestes "hebraicos", estaremos diante de períodos distintos de uma mesma língua, mesmo que se possa confirmar apenas na escrita. Neste caso, um pouco do conhecimento da sua história, possibilitaria responder a essa questão crucial e seria capaz de desfazer tal pressuposto uma vez que nos permitiria, a partir dos elementos encontrados, formularmos hipóteses comuns para essas escritas.

Em 1890, quando foram encontradas as cartas de Tell-El-Amarna, norte do Egito, de escrita babilônica datada aproximadamente do século XIV a.C., notou-se a utilização de algumas palavras da língua corrente do período, ou seja, da língua local da Palestina, cujos significados representam os mesmos da escrita hebraica atual, o que conduziu a considerá-las como as primeiras palavras hebraicas atestadas em documento escrito (RABIN, 1973).

Hadas-Lebel (1992) vai além ao declarar que tais documentos representam a fonte mais importante do uso do Acádico como língua falada na região antes do Hebraico, dandonos a impressão de que estes documentos encontrados no sítio do que foi a capital egípcia de Akhenaton marcam o momento do aparecimento do hebraico como língua falada na região.

Rabin (1973) ainda apresenta o tronco lingüístico, chamado atualmente camitosemítica ou afro-asiática, que contém a língua hebraica, originada no proto-semítico, cuja existência data aproximadamente do ano 3.000 a.C., de lugar incerto do atual Oriente Médio. Desta forma, a afirmação favorece as conclusões de J.T.Hooker (1996) que esclarece a origem da escrita hebraica diretamente do Fenício, um dos alfabetos lineares mais antigos, conforme observado na inscrição Fenícia do sarcófago de Ahiram em Biblos, datada do século XI a.C.

\footnotetext{
${ }^{1}$ A forma foi claramente demonstrada na "Tabela II - Verbo Forte com Sufixo". Hollenberg (1991: 196, 197).
} 
Hooker acredita ainda que a afirmação tenha como base o Calendário de Guezer, atribuído aos hebreus, porque contém um breve catálogo das atividades agrícolas do ano e foi escrita ainda em Fenício, provavelmente quando eles o adotaram no século X a.C. Atualmente, afirma Rabin (1973), o tronco Camito-Semítico é dividido em cinco ramos principais: o mais antigo é o Acádico ainda em escrita cuneiforme (3.000 a.C.); seguido pelo Canaanita, que inclui o Hebraico (1.500 a.C.); pelo Aramaico (900 a.C.), que aos poucos foi substituindo tanto o Acádico como o canaanita; pelo Árabe (500 d.C.) e pelo Gueze (um Árabe meridional ou Etíope clássico do século III).

Os falantes do hebraico, os patriarcas, são de origem Am-Uru, ou seja, provenientes da Mesopotâmia Ocidental, ficando difícil aceitar a língua hebraica como integrante do grupo canaanita, mas o mais importante, segundo esclarece Rabin, é que qualquer que fosse a língua falada por eles, esta deve ter recebido muitas palavras criadas pelos seus ancestrais, além de muitas outras de origem proto-semítica, mas foi em Canaã o lugar onde entraram em contato com outros povos que viveram semelhantes fatos em relação às suas próprias línguas e é do contato destes dois mundos lingüísticos que nasceu o hebraico (RABIN, 1973).

De qualquer forma, é Canaã o local onde podemos situar o início da escrita hebraica, uma vez que as evidências apontam para sua criação nesta região, principalmente reforçada pela descoberta de um conjunto de caracteres cuneiformes limitados no número de trinta símbolos em Ugarit, ao norte de Canaã, que possivelmente teria inspirado a criação da escrita alfabética. Além disso, aparece um alfabeto cuneiforme simplificado compreendendo 22 caracteres no local onde os hebreus se estabeleceram no século XIII, após a saída do Egito, onde, mais tarde, apareceria a escrita alfabética (HADAS-LEBEL, 1992), talvez como uma evolução deste.

Rabin (1973) ainda esclarece que as tribos israelitas, logo após a conquista, seguem separadamente mantendo dois fatores de ligação: reuniam-se apenas em situação de perigo ou então em ocasiões religiosas no santuário comum em Schiló. É baseado nisso que se conclui existir um dialeto próprio para cada tribo, além de diferenças lingüísticas dentro das próprias 
áreas tribais, observando, principalmente, o exemplo fornecido por Juizes 12:6. Ele apresenta a marca lingüística da palavra pronunciada schibbolet pelos homens de Gilead (aparecendo como forma comum em todo hebraico bíblico), ao contrário de sibbolet, devido à pronúncia do som sch palatal pelos homens de Gilead na forma proto-semitica, ou seja, linguodental, como o "th" do inglês, pronunciada apenas pelos homens da tribo de Efraim que ainda o conservavam.

Segundo consenso entre os historiadores, as primeiras manifestações da literatura hebraica foram escritas em textos poéticos. O texto de Hadas-Lebel (1992) afirma que ela é caracterizada pelo paralelismo ${ }^{1}$, uma forma poética sem rima, cujo efeito se produz pela tonicidade e pelo eco formado na fala/leitura da escrita bíblica.

Rabin (1973) ainda apresenta a idéia do surgimento de uma linguagem poética especial, comum, baseada nos dialetos das tribos do norte e que foram utilizados no Cântico de Débora (Jz.5), na prece de Ana (I Sam.2), na benção de Jacó (Gen.49), entre outros, além de ser uma língua corrente na interação da classe sacerdotal de Schiló com as pessoas de todas as tribos.

Quando se tornam uma ameaça, os filisteus acabam promovendo uma união maior entre as tribos, o que gerou um crescimento na comunicação, culminando com o reino de Davi que anexa Jerusalém ao território, facilitando ainda mais as relações entre as tribos do norte e do sul. Apesar disso, o desenvolvimento lingüístico alcançou maior importância com o serviço civil e obras braçais espalhadas de uma para outra área do país por Salomão, seu filho, durante seu reinado, visto que essa prática exigia uma língua unificada. Essa língua unificada, chamada yehudit (judaica), vista em II Reis 18:26 e Isaías 36:11, passa a ser utilizada em documentos e ganha prestígio entre a intelectualidade formada por sábios, escribas e profetas de diferentes tribos, gerada pelo contato com o templo e a corte. Esta yehudit é conhecida hoje como o hebraico clássico do período do primeiro templo e marca, segundo Hadas-Lebel (1992), a idade do ouro da literatura bíblica. Segundo Rabin (1973), ela é diferenciada dos

\footnotetext{
${ }^{1}$ Paralelismo é a retomada do primeiro membro da frase, com algumas variações, no segundo membro da mesma.
} 
demais escritos por duas características claras: primeiro porque evita formas semelhantes ao aramaico; segundo porque utiliza a partícula "ascher" como conjunção em lugar do "sche", utilizado no hebraico do período anterior. Bons exemplos do estilo segundo Rabin seriam os discursos de Isaías e Jeremias, pois se apresentam como um nobre veículo de expressão gerado do hebraico clássico em combinação com a retórica e a poesia retirada do paralelismo utilizado nos discursos públicos.

Logo após o reinado de Salomão ocorre a divisão política do reino, em 926 a.C., mas apesar do abalo tanto de Judá, reino do sul, como de Israel, reino do norte, continuam utilizando o hebraico clássico. Um exemplo disso é o livro de Oséias, pois, mesmo existindo diferença entre as palavras utilizadas no livro em relação às palavras dos outros livros da Bíblia, nesse período, ele não apresenta palavras aramaicas e nem utiliza a conjunção "sche", preferindo o uso do "ascher", característica do hebraico clássico.

É notório o interesse dos escribas em manter uma distância entre a escrita clássica e a fala cotidiana. Este fato tornava seu trabalho mais importante, pois os autores não escreviam diretamente seus textos e os contratavam para esta tarefa tornando-se dependentes deles. Foi, portanto, essa distância o fator de maior importância na sua conservação.

Já a partir da queda de Samaria, em 721 a.C., ocorre a substituição de uma parte dos israelitas por uma população de língua aramaica e o hebraico passa a ter um convívio permanente com o aramaico.

Porém, um evento histórico que marca preponderantemente as modificações lingüísticas, a destruição do templo de Jerusalém em 586 a.C., faz com que o hebraico clássico literário deixe de ser usado, pois seu grupo de escritores é deportado para a Babilônia, um país de escrita acádica e fala aramaica. Permanecem na Babilônia até 539 a.C., quando Ciro da Pérsia a conquista e determina o abandono do acádico para assumir o aramaico como língua de comunicação falada e escrita do império.

Provavelmente, foi esse o fato que fortaleceu a penetração de termos sumerianos já 
consagrados no acádico babilônico para o aramaico, a partir do qual penetrou no hebraico segundo exemplos apresentados por Hadas-Lebel (1992) como: lkyh (hekhal = palácio), o que, segundo Harris (1998), ocorre 80 vezes na Bíblia Hebraica; !ma ('uman = artesão); rka ('ikar = camponês); ask (kisse = cadeira) o qual, segundo Harris (1998), ocorre 136 vezes na Bíblia Hebraica, além de outros termos. O mesmo vai ocorrer com termos diretos do acadiano como: ! gs ( $s^{e}$ gan = magistrado), srs (saris = oficial/eunuco), lzm (mazal = constelação).

Durante o cativeiro babilônico, um período de setenta anos, os hebreus cativos mantiveram um hebraico clássico literário, apesar de absorverem a fala aramaica recebida neste período. Por outro lado, os camponeses/aldeões remanescentes de Jerusalém continuaram com sua língua original, o hebraico, até a época de Esdras/Neemias, mais especificamente no retorno do cativeiro, quando irá se encontrar com o aramaico (falado pelo povo libertado do cativeiro) e com seu hebraico clássico literário para receber suas influências.

Neste mesmo século (V a.C.), documentos encontrados em Elefantina, no Egito, comprovam o uso da língua aramaica nas instruções oficiais dos sátrapas a seus funcionários (cartas de Arsham), bem como em súplicas da população endereçadas às autoridades. Entre tais documentos encontra-se, a exemplo, um texto apelativo enviado pelos sacerdotes judeus da colônia de Elefantina a Bigvai, governador da Judéia, cuja resposta fora escrita também em aramaico, além de outras correspondências de cunho particular (HADAS-LEBEL, 1998).

Além dessas influências recebidas, ainda podemos adicionar aquelas ocorridas durante o domínio grego, cuja helenização, porém, não substituiu o aramaico que continuou sendo a língua das camadas populares da Palestina. Por outro lado, a reação nacionalista provocada por Judas Macabeu a partir do ano 160 a.C. não motivou a substituição do grego pelo hebraico, permanecendo inclusive durante o Império Romano, sendo utilizado como língua administrativa na Ásia.

Este período de transformações políticas e lingüísticas produziu uma importante 
literatura hebraica. Essa literatura pós-exílica demonstra tais transformações principalmente na sintaxe, uma vez que para homenagear a linguagem dos ancestrais, esses escritos procuravam imitá-los, e mesmo quando carregados de termos novos, como é o caso de Jonas e Ester, procuravam manter a sintaxe pré-exílica, o que pode ser visto inclusive na tentativa de Esdras e Neemias. O cântico de Cohélet aparentemente reflete uma camada lingüística popular e os livros das Crônicas são, sem dúvida, uma atualização em linguagem mais moderna de grandes porções dos livros de Samuel e Reis.

É possível notar em todas essas obras a modificação da sintaxe do verbo sob influência aramaica, além das necessidades textuais internas que passam a exigir formas verbais temporais. Assim formas verbais simples surgem e o uso do infinito absoluto desaparece. Além disso, é comum observar a utilização da partícula "X" (Sche) em lugar do pronome relativo rXa (Ascher) e seu uso como conjunção e elo interno das locuções. (HADASLEBEL, 1998).

Todas essas implicações acabam por conduzir o hebraico na direção oposta à vontade dos saduceus ${ }^{1}$, aproximadamente no séc. I a.C., transformando-se numa língua de estilo mesclado que combinava a gramática, a sintaxe e o vocabulário do hebraico bíblico com a do hebraico falado (RABIN, 1973).

Essa língua foi usada pelos fariseus ${ }^{2}$, pois, juntamente com o aramaico, era a língua da camada mais simples da sociedade para transmitirem seus ensinos orais, a fim de afastar o povo dos ensinos dos hereges, os Essênios, a seita do deserto. Mais tarde, durante o século II da era Cristã, utilizaram-na para redigir o material produzido nesses ensinos orais, enquanto os organizavam.

É de grande importância a presença dessa "seita do deserto" (conhecida também como seita do Mar Morto ou seita dos Essênios ${ }^{3}$ ) devido à relevância lingüística dos documentos

\footnotetext{
${ }^{1}$ Uma elite sacerdotal cuja seita dominou até a época do rei Janeu, 103-76 a.C.

${ }^{2}$ Seita religiosa que pregava o cumprimento da Lei Religiosa do país conforme interpretada pelos escribas.

${ }^{3}$ Seita que vivia em comunidades de bens anunciando a absoluta pureza religiosa por meio da abstinência estrita.
} 
encontrados, uma vez que estes atestam a preservação integral do hebraico bíblico, bem como claras exortações aos fariseus por utilizarem a linguagem "profana" (hebraico falado, língua estrangeira etc.) para ensinar a Torá. Ademais, essa mesma seita nos deixou o conhecido "rolo de cobre" escrito na linguagem falada (hebraico usado pelos fariseus) comprovando que a conheciam muito bem e que, tanto o hebraico bíblico, como o hebraico falado, se conservavam como linguagem única separadas apenas pelo valor de utilização como língua literária bíblica ou simplesmente como língua de comunicação (RABIN, 1973).

Uma vez que os sábios fariseus ensinavam por meio de pequenas palestras sobre particularidades das leis ou por comentários de versículos entremeados a relatos curtos (ilustrando sua intenção) este foi o estilo utilizado na escrita e na organização do material que deixaram como herança, cuja obra se iniciou no séc. II da E.C.. Esta consiste de duas formas: a primeira era a exegese legal e interpretativa dos livros da Torá que deu origem aos "Comentários dos Tanaítas" (Midreschey Hatanaim) e a segunda, a compilação temática das leis que deu origem aos "Comentários Adicionais" (Mischná e Tossefta), motivando, inclusive, a nomeação do hebraico falado como "linguagem da Mischná" ou "língua dos sábios" para diferenciá-lo da língua da Bíblia. A Mischná acabou por tornar-se a base do Talmude tanto de Jerusalém como da Babilônia.

Para a comunicação escrita era utilizado o hebraico mischnaico, que era a língua falada pelos fariseus na Palestina durante o primeiro século (HADAS-LEBEL, 1992).

Por outro lado, o targum $^{1}$ poderia contradizer a sobrevivência do hebraico, uma vez que as paráfrases em outra língua se prestam a facilitar a compreensão daqueles que não conhecem a língua de escrita ou dominam mais a língua de paráfrase. Isso indicaria o aramaico como sendo a língua de comunicação falada na época.

Os documentos oficiais desse período, como o contrato de casamento (Ketubá) e outros, eram escritos em aramaico por causa da convivência com a administração em aramaico, promovida pelo Império persa na Palestina durante dois séculos, tornando-o língua

\footnotetext{
${ }^{1}$ Paráfrase aramaica do texto bíblico.
} 
franca do Oriente Próximo.

Finalmente, encontramos na Mischna textos em forma de conversas que representam narrativas de anedotas, o que não seria comum em uma língua que não estivesse bem viva. Portanto, o hebraico era falado provavelmente até o século I, quando o templo de Jerusalém foi destruído no ano 70, o que provocou o empobrecimento da Judéia e empurrou seus centros intelectuais para a planície costeira - de fala aramaica - incentivando ainda mais a diáspora onde já vivia a maioria dos judeus.

Além disso, podemos levar em conta o já mencionado rolo de cobre que traz o hebraico mischnaico, língua falada no primeiro século, e também as cartas de Simão (filho de Bar Kohba), no século II, descobertas em escavações de 1952. Elas foram escritas em hebraico mischnaico, única língua de correspondência que aparece nos documentos de Murrabaat, no sudeste de Jerusalém, comprovando-o como língua falada pela população da Judéia nas épocas persa e greco-romana. Não obstante, Hadas-Lebel (1992) afirma que os patriotas judeus próximos a Bar Kohba eram capazes de exprimirem-se e compreenderem-se em três línguas distintas: hebraico mischnaico, aramaico e grego. Para tal afirmação, Lebel apoiou-se nas cartas redigidas nessas três línguas que foram descobertas em Nahal Hever no ano de 1960, além dos papiros e ostracas descobertas em Massada entre os anos de 1963/1964, aliadas a várias inscrições tumulares espalhadas pela Palestina e escritas nas três línguas.

Aparentemente a Palestina do século II era trilingüe de acordo com os documentos citados e as correspondências de Bar Kohba e, uma vez escritas em hebraico, demonstravam que a língua era usada para comunicação desde a primeira metade do século.

O estudo da gramática da Mischná começou muito mais tarde (século XIX), porém, graças às pesquisas dos estudiosos Henoch Yalon e professor Yehezkel Kutscher ${ }^{1}$, que reconstituiram a língua da Mischná a partir de manuscritos antigos, foi possível notar as diferenças existentes entre o hebraico mischnaico e o bíblico, além de perceber a clara

\footnotetext{
${ }^{1}$ KUTSCHER, E.Y. et alli - Henoch Yalon Memorial Volume, Jerusalém, Kiryat Sefer, 1965.
} 
indicação de uma evolução da linguagem bíblica para uma linguagem falada (representada na Mischná).

Essa evolução pode ser observada no aparecimento da forma verbal temporal na Mischná e do tempo presente que se conservou no hebraico moderno. No hebraico bíblico, a forma verbal é indicativa de ação inconclusa, conclusa e participial.

Aparentemente este fenômeno se deve à tendência da língua se adaptar, portanto, seria lógico pressupor a partir disto que o hebraico mischnaico é o hebraico bíblico em evolução, embora persistam alegações, segundo afirma Rabin (1973), de um estágio lingüístico anterior para a língua da Mischná em relação à língua da Bíblia, ao mesmo tempo em que se percebe grande quantidade de palavras aramaicas na Mischná apontando sua datação em período posterior sob a influência do aramaico. O hebraico mischnaico, portanto, teria se formado a partir do início do segundo templo quando a administração de Israel estava sob o domínio Persa e a língua aramaica prevalecia na fala diária dos povos não judeus exigindo que estes também a falassem nas relações de comércio, justificando, assim, tal hipótese.

O hebraico mischnaico seria o continuador do hebraico bíblico e suas diferenças encontram-se no afastamento estilístico por causa dos assuntos tratados, além daquelas comuns às línguas em contato. Algumas delas podem ser observadas no número de palavras utilizadas - quinze mil palavras na Mischná, enquanto na Bíblia temos apenas oito mil - além das modificações semânticas e as ampliações e reduções de sentido, bem como a variação de termos concretos para abstratos e vice-versa. Na realidade, o hebraico mischnaico manteve o vocabulário essencial antigo, desprezando sinônimos em desuso na época e recuperando os significados de palavras raras ou "hapax"(palavras que aparecem uma única vez na Bíblia) que deviam pertencer à língua falada do período.

Apesar das simplificações ou das reconstruções análogas e da influência aramaica, a língua da Mischná continua fiel ao essencial da morfologia, senão da sintaxe bíblica.

Hadas-Lebel (1992)

Embora o aramaico tivesse sofrido influência também do grego, que fora a língua administrativa do Oriente Romano, e até mesmo do latim, essa influência é restrita apenas ao 
vocabulário, que em sua grande maioria são substantivos através dos quais, em alguns casos, o hebraico mischnaico estrutura verbos em sua conjugação Pi'el (verbos com reforço consonantal no segundo radical), portanto, não é sem motivo que Hadas-Lebel menciona a influência aramaica na língua mischnaica. O aramaico já vinha influenciando os textos bíblicos pós exílicos, algumas partes dos quais estão originalmente escritos nesse idioma, como por exemplo, Jeremias capítulo dez, verso onze; e, ao encontrar-se com o hebraico mischnaico vai influir até mesmo na morfologia e sintaxe, além do vocabulário.

Quanto à influência na morfologia podemos notar no hebraico, principalmente da Mischna, a ocorrência do sufixo in $(! y)$ formando o plural masculino no lugar de im $(\sim \mathrm{y})$, comum do hebraico bíblico. Aparecem também as formas do tipo pe'al como KeTaV (btK = escrever), do tipo pa'ala como KaVaNaH ( hnwK = intenção), do tipo haf'ala como HaDLaKaH (hqldh = acendimento), do tipo taf'yl como TaLMYD (dymlt = aluno), principalmente para as raízes comuns das duas línguas. Observamos também formações de palavras a partir de uma mesma raiz, por exemplo: $L M D(\mathrm{dml}=$ aprende $), T a L M Y D(\mathrm{dymlt}$ = aluno) e TaLMUD $(\mathrm{dwmlt}=$ ensino $)$. Além das formações verbais schaf'el com valor factivo como SCHaKHLeL (1lkX = melhorar) e nitpa'el (hitpa'el) como NiTKaVeN $\left(! \mathrm{WKtn}=\right.$ ele intentou) que aparecem no hebraico antes do Aramaico ${ }^{1}$

Na sintaxe, começamos perceber o abandono da forma verbal aspectual e o emprego temporal dos verbos em seu lugar. As preposições passam a ser introduzidas pela partícula sche $(\mathrm{X})$ na função de pronome relativo ou por seu valor conjuntivo, além de assumir função semelhante à da partícula aramaica dil (lyd) como possessivo quando associado com $(\mathrm{l})=$ 1X literalmente significa "que é de". O mesmo ocorre com as formas compostas com o verbo hyh (hyh) no passado (rma hyh = ele dizia/tinha o costume de dizer) ou no imperativo (!d hyh = julgue/seja julgante). Além disso, o emprego do artigo como demonstrativo 
acompanhando o pronome deixa de ser usado, portanto hadavar hazé $(\mathrm{hzh}$ rbdh $=$ esta coisa) passa a ser davar zé (hz rbd = esta coisa).

Quanto ao vocabulário é difícil avaliar sua influência, visto que penetrou muitas palavras acádicas, persas e gregas via aramaico, além do próprio aramaico que nos textos bíblicos pós-exílicos já provocava a evolução do significado de muitos termos, como, por exemplo, 'olam $(\sim 1[$ = eternidade) passa a significar mundo, a palavra etz (\#[ = árvore ou madeira) passa a significar apenas árvore. Além disso, podemos acrescentar os decalques (palavras criadas a partir de raízes hebraicas para fazer equivalência a termos aramaicos), por exemplo, harbé (hbrh = muito), criado para fazer frente ao seu equivalente aramaico saggi (ygf = muito). Podemos acrescentar também a eliminação de alguns sinônimos que não eram comuns às duas línguas, por exemplo a substituição do termo schoffet (jpX = juiz) pelo termo dayan $(! \mathrm{yd})$.

São essas mudanças que atravessaram os tempos, acomodando-se e aceitando alterações durante os próximos séculos, quando a língua hebraica adormeceu como língua falada, embora nunca deixasse totalmente de ser escrita tanto no hebraico escrito (bíblico) como no hebraico falado (mischnaico). Segundo testemunhos, como o relato talmúdico, que registra o fato de uma serva do rabi Yehuda Há-Nassi ${ }^{1}$ explicar aos sábios palavras hebraicas, cujos significados já haviam sido esquecidos. Esse relato levou à adoção do ano 200 como a data que marca o fim da utilização do hebraico como língua falada, apesar da possibilidade de existirem famílias, no século IV, provenientes da Judéia que a falavam, pois uma língua não deixa de ser falada concomitantemente em todos os lugares.

De qualquer forma, podemos afirmar dois períodos de existência plena do hebraico, o escrito (bíblico) e o falado (mischnaico), apesar de o hebraico mischnaico, mesmo após ter

\footnotetext{
${ }^{1}$ Para os exemplos, vide Sáenz-Badillos (1997: 187-190).

${ }^{1}$ Yehuda Há-Nassi (135-220) - Líder religioso e político da comunidade judaica da Palestina, que organizou a Mischina (ROTH, 1967 : 704).
} 
sido declarado extinto como língua falada, nunca ter deixado de ser usado na língua escrita, pois existem midraschim ainda originais datados do séc. XI, como o Midrasch Schemot Rabá.

Como constatamos, o hebraico apresenta-se de duas formas, ou seja, dois modelos de hebraico-fonte (o bíblico e o mischnaico), que mantiveram a presença viva do hebraico.

As obrigações religiosas forçaram a maioria dos judeus a lerem e escreverem em hebraico e este passa a ser conservado como língua sagrada em separado, ou seja, sem o contato com a língua de uso na vida cotidiana, mas está claro que não foram somente as porções bíblicas e a leitura das rezas que exigiram o conhecimento do hebraico. Podemos adicionar as estas os "piyyutim" (poemas litúrgicos), cujo estilo surgiu no século III na Palestina (RABIN, 1973) e vai encontrar um dos seus mais herméticos poetas no século IX, o rabi Saadia Gaon (880-942), que escreveu uma gramática e um dicionário para a posteridade, além de apresentar seus escritos com os sinais massoréticos ${ }^{1}$ da Bíblia.

O estilo litúrgico dos piyyutim não desapareceu com o rabi Saadia Gaon, mas continuou até o século XI na Espanha quando foi influenciado pela poesia árabe, dando lugar a um novo estilo litúrgico de poesia. Este novo estilo de poesia litúrgica, bem como as inovações no vocabulário mischnaico apresentado nestes piyyutim provocaram questionamento entre os escritores que preferiram retornar ao vocabulário bíblico. Mais tarde, no século XIII, a Alemanha e a França seguem o mesmo caminho que os escritores da Espanha quanto às inovações no vocabulário mischnaico e retornam a um hebraico mischnaico quase puro.

Os escritos em prosa hebraica, presentes durante o desenvolvimento da língua, apresentam-se mais intensamente no século XI, graças aos escritos de Bar Hayya e seu contemporâneo Abraham Ibn Ezra. No século XII, apresentam-se na prosa literária hebraica dos judeus alemães que se ocupavam com a exegese bíblica e com as questões de religião e

\footnotetext{
${ }^{1}$ A partir do ano 600 surgiram grupos de pessoas que se dedicavam à transmissão do texto bíblico hebraico, também conhecido como tradição escrita, o que lhes conferia a denominação "massoretas" ou tradicionalistas. Dentre eles, destacou-se a família Ben Asher, ativa em Tiberíades na Galiléia, pela criação do sistema de representação vocálica ou da vocalização do hebraico (YEIVIN, 1980). Tal sistema proporcionou certa "homogeneidade sonora", um padrão sonoro passível de utilização como ponto inicial para o ensino do hebraico língua estrangeira.
} 
ética, dos quais destacamos os escritos de Raschi, as traduções iniciadas por Yehuda Ibn Tibbon, o hebraico mischnaico científico de Maimonides e o "Livro dos Hassidim", os quais apontam para um hebraico popular vivo.

Uma análise estilística desses escritos comparados com o estilo das produções dos judeus escritores espanhóis espalhados pela França e Itália (quando expulsos da Espanha pelos muçulmanos em 1148) mostra uma literatura em prosa escrita no hebraico mischnaico e uma literatura em prosa e poesia escrita no hebraico bíblico, constatando a existência do emprego simultâneo do hebraico mischnaico para prosa e do bíblico para poesia numa mesma comunidade.

Apesar disso os judeus falavam o idioma do país em que viviam e adotavam a língua do país que os hospedavam, excluindo-se os judeus alemães que em 1348/1349 não adotaram nenhuns desses idiomas em virtude do isolamento imposto a eles. Este fato, no entanto, permitiu a evolução da sua língua judaico-alemã, o iídiche. Quanto aos judeus espanhóis, estes levaram consigo o idioma castelhano que em contato com outras línguas, tais como o árabe, o turco e o hebraico, originou o espanhol judaico.

$\mathrm{Na}$ verdade, o hebraico coexistiu com todas as línguas faladas pelos judeus quando nos séculos XVI e XVII se multiplicam as distinções gramaticais e de sintaxe. É possível notar uma rica variedade de expressões complexas e de audaciosas alusões atestando a familiaridade com os textos bíblicos e talmúdicos.

No século XVIII, a Haskalá demonstra de forma clara a imitação do Classicismo europeu nos textos produzidos em língua hebraica. Seu aspecto formal caracteriza-se na adoção de gêneros literários europeus, poesia no estilo ocidental, ensaio, drama e romance, apesar do seu conteúdo nostálgico voltado ao período bíblico. A pureza e liberdade nacional eram exaltadas numa linguagem que se restringia rigidamente ao hebraico bíblico, além de um cuidadoso zelo pelas regras gramaticais.

A escrita da época inclui-se no âmbito da literatura hebraica moderna, excetuando a 
literatura hassídica do período que mantinha um estilo contido e sugestivo numa linguagem com ritmo e equilíbrio, porém, tanto uma como a outra foram escritas na linguagem do passado.

Numa época em que era notória a existência de uma estreita relação entre nacionalismo e língua, a literatura da Haskalá fortaleceu o desejo por uma existência livre e uma vida nacional plena (a base do sionismo), além de preparar o terreno para o ressurgimento do hebraico como linguagem cotidiana ao usar o hebraico bíblico como veículo para expressar pensamentos da era moderna.

Alguns exemplos podem ser vistos em Kalman Schulman, que traduziu "Os Mistérios de Paris", de Eugène Sue, e utilizou o mais puro hebraico bíblico para reproduzir a fala dos habitantes do submundo parisiense em 1857-60. Também em Abraham Mapu, que publicou entre 1857-64 "O hipócrita"(Haisch Hatzavua), cujos personagens opositores à Haskalá falavam numa linguagem mesclada de elementos da Michná e do Talmude; bem como em Schalom Yaacov Abramovitch (Mendele Moher Sefarim) que, em 1862, apresenta sua primeira novela, "Estudem bem", parte do seu grande romance lançado em 1868 e escrito em hebraico "Pais e Filhos", cujos protagonistas falavam com poucos elementos pós-bíblicos porque prevalecia sobremaneira o hebraico bíblico.

Apesar de Mendele ter parado de escrever em hebraico por um período de tempo, em 1885 inicia a publicação de uma novela hebraica sob o título "Ao abrigo do Trovão" (Besseter Raam). Utilizando uma linguagem hebraica que contemplava elementos de diferentes períodos lingüísticos e mantendo como base o hebraico bíblico, acrescentou palavras, expressões e formas gramaticais da Mischná, do Talmude e dos Midraschim com a finalidade de expressar conceitos ausentes na escrita bíblica, bem como criar um enriquecimento estilístico e conotativo. Seguido por seus contemporâneos, esse estilo, segundo muitos historiadores, marca o verdadeiro início da moderna literatura hebraica ${ }^{1}$.

Às aproximadamente oito mil palavras bíblicas básicas foram acrescentadas cerca de

\footnotetext{
${ }^{1}$ Conforme Rabin (1973).
} 
quatorze mil palavras mischnaicas e algumas outras produzidas por fontes medievais do Piyyut e dos escritos hebraicos até o século XVIII. Além disso, os usuários do hebraico começaram a criar palavras necessárias a partir de raízes hebraicas e até mesmo aramaicas. É neste estágio, quando todas as suas fontes hebraicas passam a ser utilizadas, que vamos localizar o hebraico moderno, apesar de alguns filólogos (RABIN, 1973) não concordarem com esta posição por creditarem maior importância aos elementos mischnaicos e discordarem do contato estrutural entre o hebraico bíblico e este.

Adicionadas a essas correntes temos os esforços do orientalista Iossef Halevy (18271917), que iniciou uma campanha ferrenha para reviver o hebraico em bases puramente bíblicas, e também a obra marcante de Eliezer Ben Yehuda (Perelman), que lançou em 1879 um artigo intitulado Scheelá Lohatá ("Uma Questão Candente"), escrito em hebraico. O artigo foi reeditado na língua original por Peretz Nikhbadá na cidade de Viena em seu periódico Haschahar sob o título "Uma questão importante". Na realidade, a obra apresenta uma teoria para o nacionalismo judaico (cujo vocábulo em língua hebraica fora criado por ele) com o estabelecimento em massa dos judeus na Palestina, mantendo como língua oficial o hebraico e visando salvar sua literatura. Vale dizer que neste artigo foi a primeira vez que se vinculou o renascimento nacional judaico com o falar hebraico.

Apesar da quase totalidade dos escritores hebraicos da época, inclusive a Organização Sionista Mundial, desprezar a idéia do renascimento do hebraico como língua falada, Ben Yehuda colocou em prática essa idéia na sua própria vida pessoal. Ele falava hebraico com sua esposa e educava seu filho puramente em hebraico, além de influenciar o mesmo sobre toda Palestina, pois esta já o empregava para fins limitados embora seu sucesso inicial não possa ser visto, uma vez que em 1902 apenas dez famílias falavam hebraico em casa, segundo atestam fontes históricas ${ }^{1}$.

A atitude mais revolucionária de Ben Yehuda foi a introdução do ensino do hebraico em língua hebraica iniciado na escola Alliance Israélite Universelle, onde lecionava e, mesmo quando debilitado por problemas de saúde, continuou difundindo a idéia do hebraico como

\footnotetext{
${ }^{1}$ Conforme Rabin (1973).
} 
língua de ensino nas escolas através de seu jornal. Sua participação ativa o levou a assumir juntamente com David Yellin ${ }^{1}$ e Chaim Hirschensohn, professores na Palestina, e Abraham Moses Luncz, impressor palestinógrafo, o "Conselho da Língua" formado em 1889/1890, com a finalidade de ampliar o uso da língua hebraica e do hebraico falado em todos os setores da população com orientação quanto ao padrão correto de pronúncia e adequação de termos para os conceitos mais necessários.

Embora tenha sido pouco o tempo de atuação desse conselho ele não desapareceu. Foi a partir da criação da "Associação de Professores", que reunia todos os professores de hebraico da Palestina, que ele se fortaleceu. A associação em comum acordo o restabeleceu e o tornou atuante com a publicação de uma terminologia de aritmética para escolas primárias. Mais tarde denominado "Academia de Língua" passou a ocupar-se com a terminologia de disciplinas inteiras até esgotá-las, evitando assim as inovações de fora.

De qualquer forma, desde a primeira aliá $^{2}$ (1882-1903), com o apoio do destacado grupo "BILU" ${ }^{3}$ (abreviação hebraica de: Casa de Jacó, ide, partamos; Isaias 2:5), que apoiava a idéia e já vinha implantando o hebraico como língua falada e como língua de instrução nas escolas e também jardins de infância e escolas de nível médio, começa-se a perceber o sucesso de Ben-Yehuda.

Com a necessidade de palavras precisas na língua em movimento recorre-se às fontes, principalmente ao Talmude, e encontram-se palavras que com uma pequena alteração semântica poderiam ser adaptadas ao uso dos falantes atuais do hebraico. Ben Yehuda foi uma grande fonte criativa a quem se deve a criação das palavras: dicionário, jornal, relógio, moda, toalha, bem como a apresentação em 1903 de um pequeno dicionário que o impulsionaria, mais tarde, em 1908, a iniciar um grande dicionário. Baseou sua pesquisa em centenas de livros que englobam vários períodos da língua. Seu trabalho, interrompido por sua morte, alcançou a conclusão com M.Z.Segal e N.H.Tur-Sinai em 1958 sob o título de Thesaurus

\footnotetext{
${ }^{1}$ Educador que popularizou o método de estudo da língua hebraica através do seu uso exclusivo durante as aulas (método direto). Chaim (1973: 104).

${ }^{2}$ Imigração à Terra Santa (Israel).

${ }^{3}$ Grupo ativista de origem russa, organizado em 1882 pelo Barão Rothschild, que inaugurou a primeira aliá.
} 
Totius Hebraitatis (Tesouro completo da língua hebraica), contendo 16 volumes num total de aproximadamente oito mil páginas.

Assim, chegamos a um ponto no qual o hebraico possui elementos para poder viver, mas é entre 1900 e 1910 que os casais jovens formados em cursos nos colégios hebraicos (cuja língua corrente era o hebraico) começam contrair matrimônio construindo famílias que educariam seus filhos no hebraico como língua de fala habitual sem nenhum esforço. A partir daí podemos registrar a conversão do hebraico para uma língua viva.

O foco principal do renascimento do hebraico continuou sendo a escola, amparado não somente pelos professores, como também pelos alunos. Um registro marcante desta participação conjunta é a união deles num boicote a uma escola que pretendia ensinar suas matérias em alemão.

Segundo recenseamento efetuado pela Organização Sionista Mundial entre 1916-1918, quarenta por cento da população judaica da Palestina tinha o Hebraico como idioma principal, mas ele alcançou seu status em 1921, quando o Mandato Britânico o reconheceu como uma das três línguas oficiais da Palestina.

A partir do surgimento de escritores como S.Y.Agnon, A.Schlonsky, Schin Schalom, entre outros, a Palestina transforma-se no centro da cultura hebraica e, conseqüentemente, o hebraico se difunde dentro e fora dela.

A influência de Yellin foi tão importante que seu método de ensino do hebraico através do hebraico ganhou expressão e passou a ser utilizado a partir da década de 50 como metodologia do Ulpan (método utilizado em Israel para o ensino do hebraico a estrangeiros).

Tais fatos corroboraram com o surgimento de escolas hebraicas tanto na Palestina como fora dela. O hebraico passou a servir como veículo de instrução e conteúdo cultural, facilitando o surgimento de sociedades de falantes de hebraico, jornais hebraicos e demais círculos culturais. Assim, o hebraico penetrou como língua viva na diáspora e após a Segunda 
Guerra Mundial, com a fundação do Estado de Israel, quando ao hebraico foi conferido o status de língua oficial do Estado.

Evidentemente, na qualidade de língua viva, o hebraico irá sofrer as transformações impostas pela evolução natural surgidas pela necessidade de expressão dos falantes, estimulados por uma população de diversas origens, na qual imigrantes recebiam como oferta uma única língua de comunicação (o hebraico), havendo a necessidade de intervenção do Estado tanto na difusão quanto na manutenção formal.

A partir dessa investigação pudemos perceber que o hebraico bíblico, mischnaico e talmúdico, é língua única e vem evoluindo talvez de forma incomum em relação às outras línguas, porém, suas modificações em qualquer que seja a área afetada não deve modificar sua estrutura formal. Apesar do grande espaço de tempo transcorrido, o hebraico permaneceu adormecido como língua falada e foi sendo pouco utilizado. Podemos acreditar que a língua hebraica se manteve fiel ao essencial da morfologia, senão da sintaxe bíblica, como afirma Hadas-Lebel em relação à língua da Mischná. 


\subsection{A Escrita Consonantal}

Ao preservar sua escrita, os cananeus e os fenícios optaram pela fixação de vinte e dois signos correspondentes às consoantes da língua. Cada um destes signos tem um nome que começa pela consoante em causa. Segundo Martinet, o primeiro, por exemplo, chamado (a) la (alef, lido da direita para esquerda) começava por a, um signo que designava um som análogo à $p, t$, ou $k^{1}$ realizado ao nível da laringe. Assim, a base da escrita hebraica permaneceu fixa na estrutura consonantal, marcando-a como mais importante do que a sonoridade vocálica que era intuída do contexto. Dessa forma, a adição de afixos consonantais passa a expressar a variação dos significados contidos nas consoantes bases, mas na fala continua a ocorrer variações vocálicas para alteração semântica.

Sua escrita permanece até o século VII d.C. sem a representação de seus sons vocálicos, isto é, a escrita somente apresentava as consoantes, mas as vogais eram supridas pelo leitor. Algumas consoantes conhecidas pela expressão latina matres lectionis (literalmente, mães de leitura ou auxiliares de leitura) foram introduzidas a partir do período monárquico para suprir, em parte, esta representação sonora, permitindo entender-se que originalmente o hebraico era uma língua de escrita consonantal.

Uma série de eventos, entre os quais o domínio de outras línguas produzido pelas grandes conquistas do período monárquico de Israel e a dispersão israelita, gerou o paulatino abandono do uso da língua para comunicação oral exigindo na escrita, portanto, elementos que reproduzissem melhor sua sonoridade condenada ao desaparecimento pelo desuso. Surgiu então as mencionadas matres lectiones para auxiliar a leitura sonora. Porém, na medida em que a língua hebraica ia se fortalecendo como "língua santa" essas "consoantes-vogais auxiliares" iam se tornando insuficientes, propiciando, assim, o surgimento de novas tentativas para preservação da sonoridade da língua, o que culminou no surgimento de um sistema de representação vocálica ou "a vocalização do hebraico" utilizado, principalmente, nos manuscritos bíblicos durante a Idade Média.

\footnotetext{
${ }^{1}$ Observando a sonoridade das consoantes francesas $p, t, k$, Martinet tentou demonstrar a sonoridade da consoante alef hebraica. Na língua portuguesa, ela deve ser entendida como uma leve oclusão glotal.
} 
A partir do ano 600, começaram a surgir grupos de pessoas que se dedicavam aos estudos do texto bíblico hebraico, também conhecido como tradição escrita, conferindo-lhes por este motivo a denominação "massoretas" ou transmissores da tradição. Dentre eles se destacou a família Ben Ascher, ativa em Tiberíades na Galiléia, pela criação do sistema de representação vocálica ou da vocalização do hebraico.

Foi no período compreendido entre aproximadamente o século VII e X d.C. que surgiram três importantes sistemas de vocalização: o sistema de vocalização palestino, o sistema de vocalização babilônico e o sistema tiberiense da família Ben Ascher. Este último alcançou o seu auge definitivo em torno da primeira metade do século X d.C. pelos trabalhos do último massoreta Aharon Ben Mosche Ben Ascher (Aharon Ben Ascher). O seu sistema de vocalização tornou-se comum e adotado por todas as comunidades judaicas no período medieval, suplantando os outros dois conforme observado na maioria dos manuscritos bíblicos hebraicos que refletem o seu método.

Ainda que o Hebraico Bíblico se apresente como uma escrita alfabética puramente consonantal, o sistema de vocalização desenvolvido por Ben Ascher nos revela sua sonoridade vocálica como importante definidor de significados a ponto de funcionar, em certos casos $^{1}$, como marcadores de coesão textual.

\footnotetext{
${ }^{1}$ Por exemplo, em expressões construtas. A forma construta ocorre para ligar dois termos, quando o segundo (absoluto) atrai a tônica principal ao apoiar-se no primeiro, o construto. Hollenberg (1991: 116).
} 


\section{BASE GRAMATICAL NA COESÃO SUFIXADA DO TEXTO HEBRAICO}

\subsection{Estabelecendo o Que e Como Pesquisar na Gramática}

Uma vez delimitado o objeto da pesquisa nos afixos da língua hebraica faz-se necessário demonstrar seu lugar no campo da lingüística especificando ainda sua posição, tanto em sentido morfológico como sintático.

Sendo assim, podemos estabelecer a lingüística textual como campo de atuação do objeto tratado, visto que os afixos hebraicos incorporam-se às raízes e imprimem o direcionamento do texto.

A lingüística textual surgiu na França dos anos 60 com a finalidade de dar conta dos mecanismos da organização textual responsáveis pela construção do sentido, passando na década de 70 a apresentar-se com duas abordagens diferentes para o texto: a dos mecanismos sintático-semânticos responsáveis pela produção do sentido e o da análise do texto como objeto cultural produzido a partir de certas condições culturais em uma relação dialógica com as condições históricas de outros textos (SITYA, p. 17). Nestes termos, chega ao Brasil somente em torno dos anos $80 \mathrm{com}$ a proposta de analisar os textos como seqüências lingüísticas coerentes entre si.

Dessas observações resulta a proposta da lingüística textual, ou seja, o estudo das frases e sua organização em um texto significativo observando suas condições de produção nos aspectos sociais, históricos e culturais - e os processos sintático-semânticos neles estabelecidos dentro da sua estrutura lingüística.

O estudo do texto exige a análise do discurso, pois esta irá demonstrar sua construção através do processo de produção do significado, ou seja, tornará explícitos os mecanismos de estruturação e interpretação que estão implícitos nos textos para explicar os caminhos da criação dos significados (SITYA, p. 20).

Nesse contexto, conforme Sitya (p. 23), a linguagem aparece como uma atividade de realização social e as palavras servem apenas como pistas para auxiliar a captar as inferências 
e a organização argumentativa de um texto. Conseqüentemente, as condições de produção do discurso, considerando o contexto e a história, se responsabilizam em mostrar os seus significados.

A maioria das pesquisas textuais surge a partir do interesse que se tem de conhecer o significado, ou seja, a idéia que o autor quer transmitir. Em função disto, podemos recorrer à afirmação de Martinet quanto ao lingüista:

$\mathrm{Na}$ sua gíria, o objeto é o referente, a idéia o significado, os sons o significante.

(Martinet, 1995)

É dentro desta realidade que tomamos exemplos do texto escrito na bíblia hebraica com a finalidade de analisar seus significados, apoiados ainda na afirmação de Martinet:

Depois de escrita, a língua pode com toda a facilidade aparecer como uma realidade permanente, perceptível independentemente dos objetos a que se refere[...] A grafia de uma língua é sempre, à partida, um decalque mais ou menos elaborado da estrutura da fala.

(Martinet, 1995)

A escrita, um possível caminho para aquisição da língua hebraica, ocorre quando a grafia reproduz a primeira articulação da linguagem, articulação em unidades de sentido, em monemas (MARTINET, p. 113).

O emprego de um silabário (sistemas de grafias em que existe um signo particular para cada sílaba pronunciada; Martinet, p. 115) apresenta o inconveniente de destruir a unidade gráfica da raiz, sempre que a vogal que se seguir a $m$ for $a, i$ ou $u$, o signo inicial da palavra será diferente, correspondendo a ma, mi e $m u$, formas gráficas absolutamente distintas. Assim, os Fenícios e os Cananeus preferiram preservar a unidade gráfica da raiz, deixando ao contexto o cuidado de indicar a identidade da palavra de forma mais precisa. Notaram, da mesma forma $m a, m i, m u$ e $m$ sem vogal seguinte.

No caso da língua hebraica, ou melhor, das línguas semíticas alfabéticas em geral, são as consoantes que armazenaram o sentido de base: por exemplo, as três consoantes mlk 
(\$1m) dispostas nesta ordem podem ter o valor de "rei" ou de "reinar"; as vogais que podem acompanhar cada consoante especificam sempre o valor da categoria gramatical que assume a raiz mlk (\$lm) num dado enunciado, mas o próprio contexto dá boas indicações nesse sentido.

A princípio, é na escrita alfabética que acontecerá nossa investigação, ou mais especificamente, em cada unidade distintiva da grafia, no fonema.

Possivelmente, para não romper o sistema de escrita consonantal, utilizavam também consoantes diversas afixas às raízes para a construção da superfície textual. Tais afixos podem ser entendidos como um ponto inicial no aprendizado do hebraico língua estrangeira, uma vez que o aprendiz esteja capacitado a identificá-los nas palavras que compõem os textos. Para isso, necessitaremos reconhecer os elementos constitutivos de uma palavra, que basicamente são dois tipos de morfemas ${ }^{1}$ : afixo e raiz. A raiz é o morfema que pode por si só constituir a base de uma palavra, por exemplo, na palavra luzir, luz é a raiz. Já o afixo é o elemento acrescentado à raiz para formar uma palavra e subdivide-se em dois tipos segundo sua posição de ocorrência: o prefixo, que se acrescenta antes da base para formar uma palavra, e o sufixo, que se acrescenta depois da base. Por exemplo, o elemento in- de infeliz é o prefixo e o elemento -idade em felicidade é um sufixo (BASÍLIO, 1989).

A resposta é muito clara do ponto de vista da língua portuguesa e talvez ocorra o mesmo na maioria das línguas existentes, de qualquer forma, uma vez que é o hebraico a nossa língua de interesse, poderemos confirmar esta ocorrência em diversas gramáticas hebraicas dentre as existentes. Hollenberg (1991: 123), por exemplo, quando cita sobre a formação das palavras apresenta as formas afixas preferindo nomeá-las de acordo com suas posições por preformativos quando no início das palavras ou aformativos quando no final das palavras.

Parece bastante lógica esta terminologia visto que esses afixos acabam por se

\footnotetext{
${ }^{1}$ Morfema é a unidade mínima de significação. Neto (1997: 70).
} 
constituírem como formativos ${ }^{1}$ das palavras hebraicas onde o preformativo indicaria o elemento mínimo anteposto à base de uma palavra para formar uma nova palavra. $\mathrm{Na}$ verdade, seria uma forma presa (não pode constituir enunciado por si só, Basílio 1989, p. 91), pois funcionaria como elemento formador do especificador da palavra anteposto à base radical que forma o seu núcleo; por exemplo, quando se antepõe o prefixo $t(t)$ ao radical ${ }^{2}$ Lmyd $\left(\right.$ dyml $^{3}$ = adjetivo passível de ser aprendido) será formado o substantivo tlmyd $(\mathrm{dymlt}=$ aluno/aprendiz $)$.

Assim, o aformativo representaria o sufixo com a mesma finalidade. Por exemplo, ao acrescentarmos o sufixo on $(! \mathrm{W})$ ao radical $q d m(\sim \mathrm{dq}=$ oriente, substantivo masculino) formamos o adjetivo qdmon $(\text { ! wmdq }=\text { oriental })^{4}$.

Segundo Basílio (1989), os afixos são como elementos essenciais para repassar a idéia de uma palavra de determinada classe gramatical para outra classe gramatical, além de poderem se apresentar como acréscimo semântico numa determinada significação lexical base, decorrente da "necessidade de formação de palavras novas" ${ }^{5}$ com a finalidade de atender $\mathrm{o}$ ato de comunicação.

No primeiro caso, propomos como exemplo o verbo agilizar, o qual, quando necessário, muda de classe gramatical, passando a ser utilizado na forma de substantivo com o acréscimo do sufixo "ção", agilização. No segundo caso, podemos observar o substantivo dólar, a partir do qual criamos um outro substantivo com o acréscimo do sufixo "eiro", doleiro $^{6}$, utilizado para indicar o indivíduo que comercializa o dólar, mantendo-se a mesma classe gramatical e o mesmo significado léxico da base, atribuindo-lhe apenas uma atividade.

Formativo é o nome genérico para qualquer elemento mínimo constituinte da palavra. Basilio (1989: 91).

Radical é o elemento constitutivo nuclear ao qual se junta outro na formação de palavras.

${ }^{3}$ Essa raiz foi formada com a inserção do infixo yod " $\mathrm{y}$ " na raiz do substantivo $\mathrm{dml}$ = estudo/conhecimento.

${ }^{4}$ Conforme: Harris, Archer \& Waltke (1998: 1318,1319)

${ }^{5}$ É impraticável à memória humana captar e guardar formas diferentes para cada necessidade de usar palavras, em seus contextos e situações, por isso as construímos a partir de léxicos conhecidos. Basílio (1989: 10).

${ }^{6}$ É também adjetivo. LUFT, Celso Pedro. Minidicionário Luft. $20^{\mathrm{a}}$ ed. São Paulo: Ática, 2002. 
Da mesma forma, na língua hebraica podemos observar os dois exemplos acima mencionados como representantes do primeiro caso, pois o adjetivo lmyd (dyml = suscetível de ser aprendido), transforma-se no substantivo tlmyd (dymlt = aluno /aquele que pode aprender) ao receber o preformativo $t(\mathrm{t})$ e o substantivo $q d m(\sim \mathrm{dq}=$ oriente $)$ transforma-se no adjetivo qdmon $(! \mathrm{wmdq}=$ oriental) ao receber o aformativo on $(! \mathrm{W})$. Já no segundo caso, propomos este mesmo adjetivo qdmon (!wmdq = oriental), que ao receber o aformativo $y(\mathrm{y})$, formará o adjetivo qdmony (ynwmdq $=$ do oriente $/$ de procedência oriental), utilizado para indicar o indivíduo/objeto procedente do lado oriental, ou seja, permanece na mesma classe gramatical utilizando o mesmo significado léxico da base e atribuindo-lhe apenas uma atividade (procedência).

Enfim, não vemos diferença entre a função dos afixos da língua portuguesa e os afixos da língua hebraica, a não ser no processo de formação das palavras e na nomenclatura escolhida pelos seus respectivos autores, porém tais diferenças são fáceis de explicar.

Na criação de uma nova palavra hebraica, conforme o processo de formação de palavras apresentado por Hollenberg, o radical, quando destacado do afixo, sempre será uma palavra que pode por si só constituir um enunciado, será uma forma livre ${ }^{1}$. Quando formada através da adição de um afixo, este será sempre uma forma presa, pois mesmo que tenha um significado sintático conhecido, não é admitido pela língua como palavra distinta, o que nos leva a concluir que no processo de formação de palavras novas hebraicas predominam as composições e, neste caso, composições com pelo menos uma base presa onde o afixo é o especificador e o radical é o núcleo.

Na língua portuguesa, os afixos em geral se prestam apenas à formação de palavras o que não ocorre na língua hebraica. Nela, além dos afixos formadores de novas palavras denominados por Hollenberg como preformativos ${ }^{2}$ e aformativos ${ }^{1}$, encontraremos outros

\footnotetext{
${ }^{1}$ Basilio (1989: 91).

${ }^{2}$ Exemplo: dyml = suscetível de ser aprendido, mais o preformativo $t$, resulta no substantivo dymlt = aluno /aquele que pode aprender.
} 
afixos diferentes com funções específicas, os quais representam a abreviação de palavras ou então consoantes próprias para esta finalidade com significados independentes e que serão afixadas em outras palavras, mantendo seus significados para a construção do texto ${ }^{2}$. Daí nossa preferência em denominar os afixos formadores de novas palavras de preformativo e aformativo, reservando os termos prefixos e sufixos para estes elementos diferenciados.

O estudo destes prefixos e sufixos tem como ponto de partida os pronomes pessoais, apesar de encontrarmos entre os prefixos as preposições, as conjunções, o artigo, o pronome relativo e interrogativo etc., e entre os sufixos os pronomes oblíquos e possessivos. Portanto, vemos a possibilidade de estabelecer o nosso ponto inicial para o aprendizado do Hebraico como língua estrangeira nesses pronomes.

\footnotetext{
${ }^{1}$ Exemplo: $\sim \mathrm{dq}=$ oriente, mais o aformativo ! $\mathrm{w}$, transforma-se no adjetivo ! $\mathrm{wmdq}=$ oriental.

圆 Um exemplo pode ser encontrado na abreviação do pronome pessoal Wnxna (nós), do qual usamos apenas sua última sílaba $\mathrm{Wn}$, como sufixo pronominal acrescido na raiz nominal tWmd (imagem) para formar a palavra WntWmd, traduzida pela expressão imagem de nós, ou seja, nossa imagem.
} 


\subsection{Os Pronomes Pessoais}

São definidos como aqueles que indicam diretamente as pessoas do discurso, de forma que o falante/escritor assume os pronomes eu/nós, empregando tu, vós, vocês, vossa excelência e outros para designar a quem se dirige, ele/ela, eles/elas para referir-se à pessoa ou ao assunto de que se fala, dividindo-os segundo suas funções exercidas nas orações, em pronomes do caso reto e pronomes do caso obliquo.

\subsubsection{Pronomes Pessoais do Caso Reto}

São aqueles que desempenham nas orações função de sujeito ou de predicativo do sujeito:

\subsubsection{Para a Primeira Pessoa, temos Eu (Singular) e Nós (Plural).}

a) - Português

eu 1. Pronome pessoal da primeira pessoa singular de ambos os gêneros 2. A personalidade de quem fala. ${ }^{1}$

nós Pronome pessoal da primeira pessoa do plural de ambos os gêneros que funciona como sujeito, predicativo e regime de preposições. ${ }^{2}$

b) - Hebraico

yn ' 3 (Any) Pronome da primeira pessoa do singular de ambos os gêneros. ${ }^{4}$

wnxn' $\left(\right.$ Anakhnu $\left.^{5}\right)$ Pronome da primeira pessoa do plural de ambos os gêneros. ${ }^{4}$

\subsubsection{Para a Segunda Pessoa, temos Tu (Singular) e Vós (Plural).}

a) - Português

tu Pronome pessoal da segunda pessoa do singular de ambos os gêneros. Indica a pessoa com quem se fala. ${ }^{1}$

vós Pronome pessoal da segunda pessoa do plural de ambos os gêneros. Usado em geral quando nos dirigimos a muito seres funcionando como sujeito, como predicativo e como

\footnotetext{
${ }^{1}$ Conforme Ferreira (2001: 301).

${ }^{2}$ Ferreira (2001: 489).

3 A língua hebraica ao contrário da língua portuguesa, é lida da direita para a esquerda.

${ }^{4}$ Segundo Brown (1996: 58).

${ }^{5} \mathrm{O}$ "kh" tem leitura aspirada como o "j" espanhol. Berezin (1995: XLIII).
} 
regime de preposições. ${ }^{2}$

b) - Hebraico

hJt ' (Atta) Pronome da segunda pessoa do singular masculino. ${ }^{3}$

$J_{t}$ (Att) Pronome da segunda pessoa do singular feminino. ${ }^{2}$

$\sim \mathrm{Ta}$ (Attem) Pronome da segunda pessoa do plural masculino. ${ }^{2}$

!Ta (Atten) Pronome da segunda pessoa do plural feminino. ${ }^{2}$

\subsubsection{Para Terceira Pessoa, temos Ele/Ela (Singular) e Eles/Elas (Plural).}

a) - Português

ela Pronome pessoal feminino de ele(ê) ${ }^{4}$

ele (ê) Pronome pessoal. Designa a terceira pessoa do masculino singular. ${ }^{5}$

Observa-se que tais pronomes da língua portuguesa não são admitidos como complementos verbais na forma culta em que serão utilizados os oblíquos.

b) - Hebraico

'wh $\left(\mathrm{Hu}^{6}\right)$ Pronome da terceira pessoa do singular masculino. ${ }^{7}$

'yh (Hy) Pronome da terceira pessoa do singular feminino. ${ }^{6}$

$\sim_{\mathrm{h}} \quad($ Hem $)$ Pronome da terceira pessoa do plural masculino. ${ }^{8}$

!h (Hen) Pronome da terceira pessoa do plural feminino. ${ }^{9}$

Observa-se também, no hebraico, que tais pronomes não são admitidos como complementos verbais na forma culta, pois, neste caso serão utilizadas preposições flexionadas ou os pronomes sufixos oblíquos. Exemplos: wtwa bhwa (ohev oto = amo o); wbha $(\text { ahevo }=\text { amo }- \text { o })^{10}$.

\footnotetext{
${ }^{1}$ Conforme Ferreira (2001: 690).

${ }^{2}$ Conforme Ferreira (2001: 717).

${ }^{3}$ Conforme Brown (1996: 87).

${ }^{4}$ Conforme Ferreira (2001: 252).

${ }^{5}$ Conforme Ferreira (2001: 717).

${ }^{6} \mathrm{O}$ "h" é aspirado, como o "h" do Inglês sempre que não estiver em final de palavras. Berezin (1995: XLIII).

${ }^{7}$ Conforme Brown (1996: 214).

${ }^{8}$ Conforme Brown (1996: 241).

${ }^{9}$ Conforme Brown (1996: 243).

${ }^{10}$ ELLIGER, Karl \& RUDOLPH Wilhelm. Bereschit. In: Bíblia Hebraica Stuttgartensia. $4^{\mathrm{a}}$.ed. Stuttgart:

Deutsche Bibelgesellschaft, 1990. p. 01.
} 


\subsubsection{Pronomes Pessoais do Caso Oblíquo - Sufixos Hebraicos}

São aqueles que nas orações desempenham funções de complemento verbal (objeto direto ou indireto) ou complemento nominal e são subdivididos de acordo com sua tonicidade em átonos e tônicos.

\subsubsection{Pronomes Pessoais do Caso Oblíquo Átonos - Sufixos Hebraicos}

\subsection{Para a Primeira Pessoa, temos Me (Singular) e Nos (Plural).}

a) - Português

me Forma oblíqua do pronome pessoal eu que funciona, geralmente, como objeto direto ou como indireto. ${ }^{1}$

nos Forma oblíqua do pronome pessoal nós que funciona, geralmente, como objeto direto ou como indireto. ${ }^{2}$

b) - Hebraico

Inicia-se aqui um novo tratamento, pois os pronomes hebraicos ${ }^{3}$ apresentam-se na forma de consoante(s), sufixando os termos regentes (nomes/verbos), em todos os casos, como uma abreviação drástica dos pronomes pessoais. ${ }^{3}$ Esses pronomes nunca aparecem isoladamente, mas sempre sufixando o termo regente. Na primeira pessoa yn ' (Any), temos como correspondente o sufixo yn ( $\mathrm{Ny}$, apresentando-se da direita para a esquerda ynREGENTE ${ }^{4}$ segundo a escrita hebraica), e de seu plural wnxn' (Anakhnu) extraímos o sufixo plural wn $(\mathrm{Nu})$, e assim por diante:

ynREGENTE $=$ forma equivalente a me (singular) do Português.

wnREGENTE $=$ forma equivalente a nos (plural) do Português.

\subsection{Para a Segunda Pessoa, temos Te (Singular) e Vos (Plural).}

a) - Português

te 1. Pronome pessoal. Designa a segunda pessoa do singular dos dois gêneros, tomada

\footnotetext{
${ }^{1}$ Conforme Luft (2002: 449).

${ }^{2}$ Conforme Ferreira (2001: 488).

${ }^{3}$ Sobre os pronomes sufixos hebraicos, Hollenberg - Budde (1991: 45-46).

${ }^{4}$ A palavra REGENTE serve apenas para indicar a presença inseparável do nome regente acompanhando o
} 
como objeto direto e equivalente a a ti. ${ }^{1}$

te 2. Pronome pessoal. Designa a segunda pessoa do singular dos dois gêneros, tomada como objeto indireto e equivalente a a ti, em ti, para ti, de ti. ${ }^{1}$

vos Pronome pessoal da segunda pessoa do plural do caso oblíquo, valendo por a vós, em vós, para vós e de vós, podendo indicar com certos verbos a voz passiva. ${ }^{2}$

b) - Hebraico

Quanto à segunda pessoa do Hebraico, temos a abreviação do pronome masculino hFFGt' (Atta) substituído por ${ }^{\wedge}(k h a)$ para indicar seu singular e o pronome feminino t' (Att) substituído por \% $\%(k h)$ para indicar seu singular.

$\wedge^{\text {REGENTE }}=$ forma equivalente a te (singular masculino) do Português.

\% REGENTE $=$ forma equivalente a te (singular feminino) do Português.

As formas plurais devem estar acompanhadas das respectivas marcas de plural, ou seja, masculinos terminam em $\sim$ e femininos terminam em ! para seus casos correspondentes, porém utilizam a mesma consoante $\$^{3}$ para marcar a segunda pessoa.

KREGENTE $=$ forma equivalente a vos (plural masculino) do Português.

! KREGENTE $=$ forma equivalente a vos (plural feminino) do Português.

\subsection{Para Terceira Pessoa O/A/Se/Lhe (Singular), Os/As/Se/Lhes (Plural)}

a) - Português

o O pronome pessoal oblíquo da terceira pessoa do singular masculino. ${ }^{4}$

a O pronome pessoal oblíquo da terceira pessoa do singular feminino. ${ }^{5}$

se Pronome pessoal. Usado como objeto direto em verbos pronominais para indicar a voz passiva e ainda como índice de indeterminação do sujeito. ${ }^{6}$

\footnotetext{
sufixo pronominal.

${ }^{1}$ Conforme Ferreira (2001: 664).

${ }^{2}$ Conforme Ferreira (2001: 717).

3 A grafia da consoante $\&<\$ \&<$ é para uso somente em final de palavras, nas demais posições utiliza-se "k". Hollenberg - Budde (1991: 03).

${ }^{4}$ Conforme Ferreira (2001: 492).

${ }^{5}$ Conforme Ferreira (2001: 01).

${ }^{6}$ Conforme Ferreira (2001: 625).
} 
Ihe Pronome pessoal. A ele, a ela (ou a você, ao senhor etc.), ou nele, nela etc., ou dele, dela etc. ${ }^{1}$.

b) - Hebraico

whREGENTE = forma equivalente a o/ se/ lhe (singular masculino) do Português.

hREGENTE = forma equivalente a a/ se/ lhe (singular feminino) do Português.

$\sim$ hREGENTE $=$ forma equivalente a os/ se/ lhes (plural masculino) do Português.

!hREGENTE = forma equivalente a as/ se/ lhes (plural feminino) do Português.

\subsubsection{Pronomes Pessoais do Caso Oblíquo Tônicos}

\subsection{Para a Primeira Pessoa, temos Mim (Singular) e Nós (Plural).}

a) - Português

mim Pronome pessoal. Forma oblíqua de eu, sempre regida de preposição. ${ }^{2}$

nós Observe nos, a forma oblíqua do pronome pessoal nós que geralmente funciona como objeto direto ou como indireto. ${ }^{3}$

b) - Hebraico (as formas pronominais são as mesmas dos Pronomes Átonos)

ynREGENTE $=$ forma equivalente a mim (singular) do Português.

wnREGENTE = forma equivalente a nós (plural), do Português.

\subsection{Para a Segunda Pessoa, temos Ti (Singular) e Vós (Plural).}

\section{a) - Português}

ti Pronome pessoal da segunda pessoa do singular que se usa acompanhada de preposição. ${ }^{4}$

vós Observe vos, pronome pessoal da segunda pessoa do plural do caso oblíquo valendo por: a vós, em vós, para vós e de vós e indicando com certos verbos a voz passiva. ${ }^{5}$

b) - Hebraico

\footnotetext{
${ }^{1}$ Conforme Ferreira (2001: 425).

${ }^{2}$ Conforme Ferreira (2001: 463).

${ }^{3}$ Conforme Ferreira (2001: 488).

${ }^{4}$ Conforme Ferreira (2001: 671).

${ }^{5}$ Conforme Ferreira (2001: 717).
} 
${ }^{\wedge}$ REGENTE $=$ forma equivalente a ti (singular masculino) do Português.

$\%$ REGENTE $=$ forma equivalente a ti (singular feminino) do Português.

$\sim \mathrm{kREGENTE}=$ forma equivalente a vós (plural masculino) do Português.

$!$ KREGENTE $=$ forma equivalente a vós (plural feminino) do Português.

\subsection{Para Terceira Pessoa, temos Ele/Ela/Si (Singular) e Eles/Elas/Si} (Plural).

a) - Português

ela Pronome pessoal feminino de ele(ê). ${ }^{1}$

ele (ê) Pronome pessoal. Designa a terceira pessoa do masculino singular. ${ }^{1}$

si Pronome feminino que tomam os pronomes ele(s), ela(s) quando antecedidos de preposição (menos com) e que se refere ao sujeito da oração. ${ }^{2}$

Estes pronomes serão sempre regidos por preposição, a partir dos quais se observam, por exemplo, as formas diferenciadas combinadas com a preposição com (comigo, contigo, consigo...).

b) - Hebraico

whREGENTE $=$ forma equivalente a ele/ si (singular masculino) do Português.

hREGENTE = forma equivalente a ela/ si (singular feminino) do Português.

$\sim$ hREGENTE $=$ forma equivalente a eles/ si (plural masculino) do Português.

!hREGENTE $=$ forma equivalente a elas/ si (plural feminino) do Português.

${ }^{1}$ Conforme Ferreira (2001: 252).

${ }^{2}$ Conforme Ferreira (2001: 635). 


\subsection{Os Pronomes Possessivos - Sufixos Hebraicos}

São aqueles que fazem referência às pessoas do discurso, atribuindo-lhes alguma posse.

3.3.1 Para a Primeira Pessoa, temos Meu, Minha, Meus, Minhas (Singular), Nosso, Nossa, Nossos, Nossas (Plural).

a) - Português

$\boldsymbol{m e u}(\mathbf{s})$ pronome: pertencente a, ou próprio da, ou sentido, experimentado pela pessoa que fala. ${ }^{1}$

minha(s) pronome possessivo feminino de meu. ${ }^{2}$

nosso(s) pronome: pertencente a, ou próprio de, ou experimentado por nós. ${ }^{3}$

b) - Hebraico

yREGENTE $=$ forma equivalente a meu, minha, meus, minhas (singular) do Português. wnREGENTE = forma equivalente a nosso, nossa, nossos, nossas (plural) do Português.

\subsubsection{Para a Segunda Pessoa, temos Teu, Tua, Teus, Tuas (Singular) e Vosso,} Vossa, Vossos, Vossas (Plural).

a) - Português

teu(s) pronome possessivo pertencente a, ou próprio da, ou experimentado, ou inspirado pela pessoa a quem se fala. ${ }^{4}$

vosso(s) pronome pertencente $\mathrm{a}(\mathrm{s})$, ou próprio $\mathrm{da}(\mathrm{s})$, ou experimentado, ou inspirado pela(s) pessoa(s) a quem se fala por vós. ${ }^{5}$

b) - Hebraico

${ }^{\wedge}$ REGENTE $=$ forma equivalente a teu, teus (singular masculino) do Português.

\%REGENTE = forma equivalente a tua, tuas (singular feminino) do Português.

$\sim$ KREGENTE $=$ forma equivalente a vosso, vossos (plural masculino) do Português.

\footnotetext{
${ }^{1}$ Conforme Ferreira (2001: 460).

${ }^{2}$ Conforme Ferreira (2001: 463).

${ }^{3}$ Conforme Ferreira (2001: 488).

${ }^{4}$ Conforme Ferreira (2001: 670).

${ }^{5}$ Conforme Ferreira (2001: 717).
} 
!kREGENTE = forma equivalente a vossa, vossas (plural feminino) do Português.

\subsubsection{Para Terceira Pessoa, temos Seu, Sua, Seus, Suas (Singular) e Seu, Sua, Seus, Suas (Plural).}

a) - Português

seu(s) pronome pertencente a(s), ou próprio da(s), ou sentido pela(s) pessoa(s) de quem se fala: dele(s), dela(s). ${ }^{1}$

sua(s) pronome flexionado de seu. ${ }^{2}$

Observe que no caso do Português do Brasil, a forma do possessivo depende da pessoa gramatical a quem se refere e concorda em gênero e número com o objeto possuído. Exemplo: Dou meu apoio e minha solidariedade.

b) - Hebraico

whREGENTE = forma equivalente a seu/sua, seus/suas (singular masculino) do Português. hREGENTE = forma equivalente a seu/sua, seus/suas (singular feminino) do Português. $\sim$ hREGENTE $=$ forma equivalente a seu/sua, seus/suas (plural masculino) do Português. !hREGENTE = forma equivalente a seu/sua, seus/suas (plural feminino) do Português.

Observe que no caso do Hebraico, a forma do possessivo depende da pessoa gramatical a quem se refere, porém, concorda em gênero e número com o possuidor.

Exemplo: Gênesis 16:06 (W : wy - tyviPareB. )

$$
\begin{array}{r}
\text { xrbTw yrf hN[Tw } * * * \% \text { yny[B bAJh } * \text { Hl-yf[ } * \% \text { dyB } * \% \text { txpv } \\
\text { hNh yrf-la } \\
\sim \text { rba rmaYw } \\
{ }^{* * * *} \text { hynPm }
\end{array}
$$

"E disse Abrão a Sarai: Eis que tua *serva está na tua *mão, faze-lhe** o que bom é aos teu(s) ***olhos. E afligiu-a Sarai, e ela fugiu de sua(s) ****faces."

* Sufixo Hebraico 2a . Pessoa Singular - Pronome Possessivo $2^{\text {a }}$. Pessoa do Singular.

** Sufixo Hebraico $3^{\text {a }}$. Pessoa Singular Feminino - Pronome Oblíquo $3^{\text {a }}$. Pessoa do Singular.

\footnotetext{
${ }^{1}$ Conforme Ferreira (2001: 634).

${ }^{2}$ Conforme Ferreira (2001: 647).

${ }^{3}$ Tradução Almeida (1977: 15).
} 
*** Sufixo Hebraico 2a Pessoa Singular - Pronome Possessivo $2^{\mathrm{a}}$. Pessoa do Plural.

**** Sufixo Hebraico 3 ${ }^{\text {a }}$. Pessoa Singular Feminino - Pronome Oblíquo $3^{\mathrm{a}}$. Pessoa do Plural.

Para uma visão de conjunto podemos sistematizar essas informações na Tabela 3 Quadro Contrastivo dos Pronomes Sufixos do Hebraico com o Português:

\begin{tabular}{|c|c|c|c|c|c|c|c|}
\hline \multicolumn{8}{|c|}{ PRONOMES } \\
\hline \multicolumn{6}{|c|}{ PESSOAIS } & \multicolumn{2}{|c|}{ POSSESSIVOS } \\
\hline \multicolumn{3}{|c|}{ PORTUGUÊS } & \multicolumn{3}{|c|}{ HEBRAICO } & \multirow{3}{*}{ PORTUGUÊS } & \multirow{3}{*}{$\begin{array}{l}\text { HEBRAICO } \\
\text { (SUFIXOS) }\end{array}$} \\
\hline \multirow[t]{2}{*}{$\begin{array}{l}\text { Caso } \\
\text { Reto }\end{array}$} & \multicolumn{2}{|c|}{ Caso Oblíquo } & \multirow{2}{*}{$\begin{array}{l}\text { Caso } \\
\text { Reto }\end{array}$} & \multicolumn{2}{|c|}{$\begin{array}{c}\text { Caso Oblíquo } \\
\text { (SUFIXOS) }\end{array}$} & & \\
\hline & Átono & Tônico & & Átono & Tônico & & \\
\hline eu & me & $\operatorname{mim}$ & yna & yn & yn & $\operatorname{meu}(\mathrm{s}) / \operatorname{minha}(\mathrm{s})$ & $\mathrm{y}$ \\
\hline tu & te & ti & hta & $\wedge$ & $\wedge$ & teu(s) & $\wedge$ \\
\hline tu $(\mathrm{F} .)^{1}$ & te & ti & ta & $0 \%$ & $0 \%$ & $\operatorname{tua}(\mathrm{s})$ & $\%$ \\
\hline ele & o/se/lhe & ele/si & awh & wh & wh & seu/dele & wh \\
\hline ela & $\mathrm{a} / \mathrm{se} / \mathrm{lhe}$ & ela/si & ayh & $\mathrm{h}$ & $\mathrm{h}$ & sua/dela & $\mathrm{h}$ \\
\hline nós & nos & nós & $\begin{array}{c}\text { wnx } \\
\text { na }\end{array}$ & Wn & Wn & $\operatorname{nosso}(\mathrm{s}) / \operatorname{nossa}(\mathrm{s})$ & Wn \\
\hline vós & vos & vós & $\sim$ ta & $\sim \mathrm{k}$ & $\sim \mathrm{k}$ & $\operatorname{vosso}(s)$ & $\sim \mathrm{K}$ \\
\hline vós (F.) & vos & vós & !ta & $! \mathrm{k}$ & $! k$ & $\operatorname{vossa}(s)$ & $! \mathrm{k}$ \\
\hline eles & os/se/lhes & eles/si & $\sim \mathrm{h}$ & $\sim \mathrm{h}$ & $\sim \mathrm{h}$ & seus/deles & $\sim \mathrm{h}$ \\
\hline elas & as/se/lhes & elas/si & $! \mathrm{h}$ & $! \mathrm{h}$ & $! \mathrm{h}$ & suas/delas & !h \\
\hline
\end{tabular}

Os pronomes sufixos de terceira pessoa $(! \mathrm{h}, \sim \mathrm{h}, \mathrm{wh})$ formados por mais de uma consoante podem aparecer mais resumidamente, ou seja, apenas com a última consoante, visto que o "h" é frequentemente assimilado" quando se encontra entre duas vogais durante a sufixação, por exemplo, o Wh aparece mais comumente como $\mathrm{W}$, o $\sim \mathrm{h}$ poderá aparecer como $\sim$ e o !h como ! sem modificar seu significado.

Observando a tabela ainda podemos considerar:

\footnotetext{
${ }^{1}(\mathrm{~F})=$. Feminino
} 
a) Os pronomes pessoais do hebraico utilizam formas masculinas e femininas bem definidas para as segundas e terceiras pessoas, apesar da combinação de gênero e número, bem como sua forma de utilização, ser equivalente ao da língua portuguesa. Porém, quando utilizamos os pronomes oblíquos e possessivos essa distinção se torna mais visível, pois, na língua hebraica, a combinação de gênero e número se faz com o possuidor, ao contrário da língua portuguesa, que a faz com o objeto possuído. Assim, o nosso objeto possuído, representado na raiz hebraica que significa a palavra casa, byt (tyb), acrescida com o sufixo indicativo de posse da terceira pessoa do masculino singular $w(\mathrm{~W})$, resulta bytw (Wtyb) que significa literalmente, seu casa, cuja forma é considerada erro de concordância na língua portuguesa, embora possa ser traduzida pela expressão casa dele. Essa forma gráfica hebraica só ocorre quando o possuidor da referida casa for masculino, pois, se feminino, receberá o sufixo indicativo de posse, correspondente ao feminino singular da terceira pessoa, ou seja, (h), e sua forma gráfica será byth (htyb = sua casa/casa dela). Neste caso, precisamos de duas formas para expressar sua casa em língua hebraica, uma para o masculino (Wtyb) e outra para o feminino (htyb), enquanto que na língua portuguesa utilizamos apenas uma forma para expressar a posse da terceira pessoa do singular, tanto para o masculino quanto para o feminino, pois a concordância ocorrerá entre o pronome e o substantivo (objeto possuído) que o acompanha, portanto, nosso exemplo poderá ser traduzido para a língua portuguesa pela expressão sua casa em ambos os casos.

b) O hebraico utiliza os mesmos sufixos dos pronomes possessivos para todas as formas do caso oblíquo em suas respectivas pessoas verbais. Assim, o sufixo pronominal $k h a\left({ }^{\wedge}\right)$ poderá ser utilizado, tanto no substantivo casa $\left(\right.$ byt $=$ tyb) para formar a expressão bytkha $\left(\wedge^{\wedge}\right.$ tyb $=$ tua casa), quanto na flexão pronominal da segunda pessoa do singular masculino concluso do verbo guardar $($ schmrt $=\operatorname{trmX})$, para formar a expressão schmrtkha $\left({ }^{\wedge} \operatorname{trmX}=\right.$ guardaste te). Essa aplicação da forma que representa o pronome sufixo $k h a\left({ }^{\wedge}\right)$ na função oblíqua, bem como a dos demais pronomes sufixos, poderá ser utilizada em todas as flexões pronominais

\footnotetext{
${ }^{1}$ Entre outras ocorrências, a assimilação é a mais comum. Conforme Hollenberg (1991: 27C).
} 
dos verbos, além de poder também acompanhar raízes representativas de objetos possuíveis, para indicar sua posse.

Baseado nos pronomes pessoais, a forma sufixal do verbo hebraico é a flexão pronominal, conforme demonstramos no quadro abaixo:

Tabela 4 Quadro de Flexão Pronominal do Verbo Concluso Hebraico: ${ }^{1}$

\begin{tabular}{|c|c|c|c|}
\hline $\begin{array}{c}\text { Pronome } \\
\text { Pessoal do } \\
\text { Português }\end{array}$ & $\begin{array}{c}\text { Pronome } \\
\text { Pessoal do } \\
\text { Hebraico }\end{array}$ & $\begin{array}{c}\text { Verbo na Forma } \\
\text { Conclusa } \\
\text { (Passado) }\end{array}$ & $\begin{array}{c}\text { Sonoridade } \\
\text { do sufixo } \\
\text { verbal }\end{array}$ \\
\hline eu & yna & Ytxxx & ty \\
\hline tu & hta & txxx & ta \\
\hline tu (F.) & ta & Txxx & t \\
\hline ele & awh & xxx & \\
\hline ela & ayh & hxxx & $\mathrm{a}$ \\
\hline nós & Wnxna & Wnxxx & nu \\
\hline vós & $\sim$ ta & $\sim$ txxx & tem \\
\hline vós (F.) & !ta & !txxx & ten \\
\hline eles & $\sim x$ & Wxxx & $\mathrm{u}$ \\
\hline elas & !x & $\mathrm{Wxxx}$ & $\mathrm{u}$ \\
\hline
\end{tabular}

No quadro é possível notar a incidência das mesmas consoantes, tanto nos sufixos pronominais quanto nos seus correspondentes observados na construção do verbo concluso, e quando não, no mínimo uma aproximação fonética (sonora) expressiva na maioria dos sufixos e em seus correspondentes, cuja relação direta garante sua apresentação como única forma sufixal tanto para os verbos conclusos quanto para os pronomes em geral.

Encontramos outros sufixos diversos na língua hebraica, tais como:

a - He-locativo ${ }^{3}$ h $(h)$ para indicar direção. Exemplo: htybh (hbyth), para a casa (em

\footnotetext{
${ }^{1}$ Consideramos forma "conclusa" todas as formas de passado. Hollenberg (1991: 58).

${ }^{2} \mathrm{O}$ "xxx" representa uma raiz verbal qualquer, da língua hebraica, invariável, durante esta conjugação.

${ }^{3}$ Marcador da forma locativa que Hollenberg apresenta como terminação acusativa do Hebraico antigo, pois é
} 
direção da casa). Observe, então, que o h (h) inicial está funcionando como definidor e a raiz tyb $(b y t)=$ casa.

$\mathrm{b}-H e$-feminino ${ }^{1} \mathrm{~h}(h)$ é a desinência para informar que a palavra está no feminino, apesar de muitos nomes femininos não apresentarem uma desinência específica. Exemplos: $\operatorname{lgr}(\mathrm{rgl})$ = perna, é um nome feminino sem desinência, e hbwj $(t w v h)^{2}=$ boa é o feminino de bwj $(t w v)^{1}=$ bom (os adjetivos femininos sempre recebem uma desinência). No caso de verbos, poderá aparecer na conjugação do inconcluso como plural feminino, mas exigirá um $\square$ (n) imediatamente antes e $\mathrm{o}^{\square}(t)$ prefixando. Exemplos: hndbkt $(t k h v d n h)=$ vós louvareis ou elas louvarão (feminino) do verbo $\mathrm{dbk}(k v d)=$ louvar/honrar.

$\mathrm{c}$ - He-aformativo verbal $\mathrm{h}(h)$ forma o imperativo adortativo ao ser adicionado no final dos verbos imperativos da segunda pessoa do singular com a finalidade de enfatizá-lo ${ }^{3}$. Exemplo: hjpX $\quad($ schfth $)=$ julga! em Salmo 82:8 de jpX $\quad($ schft $)=$ julga!.

$\mathrm{d}-T a v$-feminino ${ }^{\circ}(t)$ é igualmente ao $\mathrm{h}(h)$ He-feminino a desinência para nomes femininos singulares, podendo representar o nome feminino, como também representar o estado construto $^{4}$ feminino ${ }^{5}$. Exemplos: trbxm $(m k h b r t)=$ caderno; hdwhy tklm $(m l k t \text { yhwdh })^{1}$ $=$ a rainha de Judá, em que hklm $(m l k h)=$ rainha.

e - Waw-Tav tw $(w t)^{1}$ são duas consoantes que se unem para substituir o $\mathrm{h}(h)$ na

\footnotetext{
acrescentado atonicamente a um substantivo para indicar direção/local. Hollenberg (1991: 147).

${ }^{1}$ A desinência de feminino é igual ao He-locativo, mas é diferenciado pelo contexto.

${ }^{2}$ Note que a consoante $\mathrm{W}$ aparece sempre transliterada por $w$, pois é matriz de leitura, conforme $\S 2^{\circ}$, p.30, mas pode representar tanto a vogal o como a vogal $u$.

${ }^{3}$ Conforme Kelley (1998: 207).

${ }^{4} \mathrm{O}$ estado construto é aquele que uma determinada raiz assume ao criar uma relação de dependência com a raiz que se encontra imediatamente depois dela na oração. Hollenberg (1991: 116).

${ }^{5}$ Nos demais encontros de substantivos singulares com terminação em consoantes diferentes de $\mathrm{h}(h)$ não
} 
formação do plural dos adjetivos femininos, sem exceção. Exemplo: hbwj $(t w v h)^{1}=$ boa forma o plural twbwj $(t w v w t)^{1}=$ boas. É também a forma do plural dos substantivos femininos. Exemplo: hklm (mlkh/rainha) $=$ twklm $\left(\mathrm{mlkwt}^{1} / \mathrm{rainhas}\right)$.

f - Yod-Mem y (ym) é a sufixação característica do plural dos nomes masculinos. São poucas as exceções. Exemplo: rwby $\downarrow$ (gybwr ${ }^{1} /$ herói) $=\sim$ yrwby $\downarrow$ (gybwrym ${ }^{1} /$ heróis).

g - Yod-Mem y (ym), apesar da escrita ser igual à anterior, esta sufixação pertence ao plural dual dos substantivos e é utilizada: para elementos existentes aos pares na natureza, como olhos e pés, para designar duplos conceitos temporais (dois anos, dois dias, duas semanas etc.). Sua significação será observada no contexto se admitirmos que a única diferença entre elas é a sonoridade vocálica, não contempladas por ora nesta pesquisa porque eram intuídas pelos falantes da língua. Exemplo: $\sim$ ydy $(y d y m)=$ mãos (literalmente duas mãos), ymwy $($ ywmym $)=$ dois dias.

h - Tav-Yod-Mem yt (tym) é a sufixação do feminino dual das palavras terminadas em $\mathrm{h}$ (h) Exemplos: $\sim \mathrm{ytpX}($ schftym $)=$ lábios ou $\sim \mathrm{ytnX}($ schntym $)=$ dois anos.

i - Yod $\mathrm{y}(y)^{1}$, além de aparecer junto do tav $(\mathrm{yt}=t y)$ como sufixo verbal da primeira pessoa do singular do concluso poderá aparecer como sufixo feminino da segunda pessoa do singular do verbo inconcluso ${ }^{2}$, mas neste caso exigirá o ${ }^{\square}(t)$ prefixando a raiz. Exemplo: ydbkt $(t k v d y)=$ ela louvará do verbo dbk $(k v d)=$ louvar/honrar. Podemos assinalar ainda sua presença como sufixo do plural dos substantivos masculinos no estado construto. Nestes acontece mudança consonantal, há sim uma alteração vocálica.

${ }^{1}$ A terminação $\mathrm{Y}(y)$ é semelhante ao sufixo da primeira pessoa do verbo concluso, bem como, ao aformativo indicativo de procedência, e será diferenciado apenas pela sonoridade vocálica, intuída pelos falantes da língua, portanto, seu significado só será percebido na observação do contexto.

${ }^{2}$ Consideramos inconcluso todos os tempos verbais que não representem ações simultâneas ao momento da fala, 
casos, ocorre a supressão da consoante $\boldsymbol{K}(m)$ do final da palavra para fazer tal indicação. Exemplo: bhz ydy (ydym zhv) = mãos, ouro; porém bhz ydy (ydy zhv) = mãos de ouro.

j - O mesmo Yod $\uparrow(y)$ é utilizado como aformativo indicativo do membro de uma coletividade/procedência ${ }^{1}$, ou seja, forma um adjetivo. Exemplo: yrb[ ('vry) $=$ hebreu/ hebraico.

k - Yod-Tav ty (yt) representa a forma aformativa feminina indicativa de membro de uma coletividade/procedência, além de ser o aformativo formador de substantivos femininos abstratos a partir de um concreto. Exemplos: tyrb[ ('vryt) = hebréia/hebraica, tyXar $\left(r^{\prime}\right.$ schyt $)=$ começo, do concreto Xar $\left(r^{\prime} s c h\right)=$ cabeça.

1 - Yod-Waw Wy $(y w)$ é a sufixação utilizada para a terceira pessoa do possessivo plural masculino. Exemplo: Wydy $(y d y w)=$ suas mãos, literalmente mãos de ele (dele). É importante lembrar que o waw $\boldsymbol{K}(w)$ também é sufixo pronominal de terceira pessoa do masculino e sufixo do plural masculino dos verbos. Em oposição, a forma comum do feminino plural se apresenta com o sufixo comum correspondente $(\mathrm{h})$, no caso da terceira pessoa do singular feminino, na qual temos: hydy = suas mãos, literalmente mãos de ela (dela).

m - O mem $\boldsymbol{K}$ além de sufixo verbal/pronominal de terceira pessoa do plural masculino também é aformativo para expressões adverbiais. Exemplo: $\sim$ mwy $(y w m m)=$ de dia, do substantivo: $\sim \mathrm{Wy}(y w m)=$ dia.

n - O nun $\diamond$ além de sufixo verbal/pronominal de terceira pessoa do plural feminino, bem

ou ações passadas. Hollenberg (1991: 58).

${ }^{1}$ Conforme Hollenberg (1991: 124). 
como o waw-nun !W também são aformativos formadores de novas palavras. Formam substantivos derivados de outros substantivos, verbos e adjetivos. Exemplos: !xlwX = mesa (tablado de couro utilizado para dispor a refeição) é substantivo formado a partir do substantivo $\mathrm{xlX}=$ couro não curtido e ! $\mathrm{WXar}=$ primeiro é adjetivo proveniente do substantivo Xar = cabeça.

o - O lamed 1 é usado como aformativo para dar sentido coletivo. Exemplos: de $\sim \mathrm{rk}=$ vinha, temos $1 \mathrm{mrk}=$ pomar, e de @rr $[=$ gotejar, temos $1 \mathrm{pr}[=$ neblina/nuvens negras.

Neste capítulo, os sufixos hebraicos, embora não seja possível garantir a presença de todos, contemplamos a grande maioria desses que, juntamente com os prefixos, nos ajudarão a entender a construção textual da escrita hebraica.

\subsection{Os Pronomes Prefixos Hebraico}

O estudo dos sufixos do hebraico teve como ponto de partida uma categoria gramatical predominante, os pronomes, que se apresentaram como a base da maioria dos sufixos, o que não ocorrerá com os prefixos, pois se houver uma categoria predominante não será expressiva o suficiente para justificar-se como tal.

Ao admitirmos os pronomes como ponto de partida para a análise dos sufixos, devemos também admiti-los para a análise dos prefixos, apesar da escolha só se justificar na condição de aceitarmos a flexão dos verbos por uma redução drástica dos pronomes pessoais que, ao sufixar sua raiz, forma a conjugação conclusa e, em oposição, ao prefixá-la, forma a conjugação inconclusa.

Embora a nomenclatura "pronome prefixo hebraico" não apareça nas gramáticas 
tradicionais ${ }^{1}$, mas já que apresentamos o verbo sufixado numa tabela representando sua flexão e a correspondência consonantal com o pronome, faremos o mesmo com o verbo prefixado.

Tabela 5 Quadro de Flexão Pronominal do Verbo Inconcluso Hebraico:

\begin{tabular}{|c|c|c|c|c|}
\hline $\begin{array}{c}\text { Pronome } \\
\text { Pessoal } \\
\text { do Português }\end{array}$ & $\begin{array}{c}\text { Pronome } \\
\text { Pessoal } \\
\text { do Hebraico }\end{array}$ & $\begin{array}{c}\text { Verbo } \\
\text { na Forma } \\
\text { Inconclusa }\end{array}$ & Prefixo Verbal & $\begin{array}{l}\text { Marcas Sufixais do } \\
\text { Verbo Inconcluso } \\
\text { Masculino/Feminino }\end{array}$ \\
\hline eu & yna & xxxa & $\mathrm{a}$ & \\
\hline tu & hta & xxxt & $\mathrm{t}$ & \\
\hline $\operatorname{tu}(\mathrm{F})$ & ta & yxxxt & $\mathrm{t}$ & $\mathrm{y}$ \\
\hline ele & awh & XXXY & $\mathrm{y}$ & \\
\hline ela & ayh & xxxt & $\mathrm{t}$ & \\
\hline nós & Wnxna & XXXn & $\mathrm{n}$ & \\
\hline vós & $\sim$ ta & WXXXt & $\mathrm{t}$ & W \\
\hline vós(F) & !ta & hnxxxt & $\mathrm{t}$ & $\mathrm{hn}$ \\
\hline eles & $\sim \mathrm{h}$ & wxxxy & $\mathrm{y}$ & $\mathrm{W}$ \\
\hline elas & $! h$ & hnxxxt & $\mathrm{t}$ & $\mathrm{hn}$ \\
\hline
\end{tabular}

Conforme observamos na tabela, creditar às consoantes iniciais prefixas da conjugação do verbo seu valor pronominal, mesmo que de forma muito simplista, não deixa de ter certa coerência. A primeira pessoa (prefixos: plural $\mathrm{n}$ e singular a) sempre representa o gênero comum. A segunda pessoa diferencia o masculino (prefixo t) do feminino (também, prefixo t) com a adição de um sufixo diferenciador para feminino singular inconcluso (sufixo y com prefixo t). A segunda e terceira pessoas do plural masculino são semelhantes à forma correspondente no singular, mas se diferenciam por meio do sufixo comum de plural de verbos (sufixo $\mathrm{W}$ com prefixo $\mathrm{t}$ para a segunda pessoa e sufixo $\mathrm{W}$ com prefixo $\mathrm{y}$ para a terceira pessoa). Uma forma feminina freqüente nas escritas bíblicas, porém, em desuso no hebraico escrito atualmente, fará da mesma maneira a diferenciação, adicionando o sufixo para plural feminino inconcluso (sufixo hn com prefixo $t$ para a segunda e terceira pessoa).

\footnotetext{
${ }^{1}$ Hollemberg (1991: 60). Kelley (1998: 160). Preferem apresentar estes prefixos como preformativo.
} 
Mesmo que esses prefixos sejam considerados preformativos, eles não deixam de ser prefixos pronominais, o real objeto de nossa investigação. Juntamente com eles, o hebraico utiliza outros prefixos que atuam como preposições, conjunções e conectores, conforme relacionados abaixo:

a - Waw W é um dos prefixos do hebraico, cuja sintaxe é extremamente complexa. Como conhecimento inicial, ou seja, um ponto de partida é possível admiti-lo como "e" conjunção. As aplicações textuais desse prefixo é bastante variada e complexa, o que podemos exemplificar pelas formas verbais bíblicas Weqatal $^{1}$ e Wayyiqtol $^{2}$, a forma predominante na narrativa bíblica, que indica a ação em terceira pessoa do passado masculino. Exemplo: btky $(y k t v)=$ ele escreverá, quando na forma Wayyiqtol btkyw (wyktv) será entendido como e ele escreveu.

b - Beyt b também é prefixo, e, como o anterior, sua sintaxe é bastante complexa, mesmo assim, via de regra, traduzimo-lo como a preposição "em", podendo ou não conter o artigo. No hebraico, o artigo é o mesmo tanto para o masculino/feminino singular como para o plural. Neste caso, a preposição assume a função locativa (no, na, nos, nas). Além destes significados, é possível observar no relato bíblico a diversidade de funções que essa preposição pode assumir na sintaxe hebraica, das quais destacamos e exemplificamos: a função modal, conforme observada no livro de Salmos, capítulo sessenta e seis, verso treze: twlw[b \$tyb awba = "entrarei em tua casa com holocaustos"”; a função atributiva, ou seja, atribuindo qualidade, conforme se apresenta no verso três do capítulo seis do livro do Exxodo/twmv: hl yt[dwn al hwhy ymvW ydv lab bq[y-law qxcy-la hrba-la araw = "E eu apareci a Abraão, e a Isaque, e a Jacó, como (na forma de/na qualidade de) o Deus todo poderoso, mas pelo meu nome o Senhor não lhes fui perfeitamente

\footnotetext{
${ }^{1}$ Hollenberg (1991: 66). Apresenta este waw como waw consecutivo.

${ }^{2}$ Conforme Joüon (1993: 387).

${ }^{3}$ Tradução Almeida (1977:572)
} 
conhecido" ; a função instrumental, que aparece na primeira parte do verso nove do capítulo dois do livro dos Salmos / ylht: lzrb jbXb $\sim[\mathrm{rt}=$ "Tu farás trovejar pela (por meio da, através da) vara de ferro"2. Esse prefixo pode também direcionar a ação verbal, conforme se exemplifica na primeira parte do verso quatro do capítulo vinte e três do livro de I Samuel / a lamv: hwhy Whn[yw hwhyb laXl dwd dw[@swyw ="Então, Davi tornou a consultar ao SENHOR, e o SENHOR lhe respondeu"3, porém, quando estiver antes do verbo no infinitivo (com ou sem sufixo pronominal), expressará simultaneidade, por exemplo: $\mathrm{wrbdb}=$ enquanto ele falava, ou, ainda, pode indicar finalidade, conforme o verso vinte e nove do capítulo dezoito de Gênesis 甶tyvarb(ग) 'hNjQh ${ }^{\wedge} \mathrm{TB}$ lxrB $\sim \mathrm{ynv}[\mathrm{bv}$ $\wedge \mathrm{db}[\mathrm{a}$ rmaYw lxr-ta bq[y bhaYw =

"E Jacó amava a Raquel, e disse: Sete anos te servirei por Raquel, tua filha menor".

c - Kaf $\mathrm{k}$ é o prefixo equivalente a "como"(comparativo) da língua portuguesa, porém, ao prefixar um numeral expressará aproximação. Exemplo: Xya tamk = cerca de cem homens/aproximadamente cem homens, mas ao prefixar o verbo no infinitivo funcionará como o beyt, ou seja, expressará simultaneidade. Exemplo: awbk = no momento em que ele chegou/no momento do chegar. Essa preposição aparece constantemente prefixando a partícula relativadora do hebraico $(\mathrm{rXa})^{4}$ para formar a conjunção $\mathrm{rXak}=$ assim como, quando, porque.

d - Lamed 1 é o prefixo indicativo de direção, além das possibilidades seguintes:

d1 - ser utilizado como sinal do objeto sempre em relação ao sujeito. Exemplo: !kl wldx = parem/cessem (vocês).

d2 - utilizado como possessivo. Exemplo: yXal ! $\mathrm{b}=$ um filho de Ischai.

d3 - utilizado como adjunto adverbial. Exemplo: $\mathrm{t}[1=$ quando $(\mathrm{t}[=$ tempo $+1=$ para $)$.

\footnotetext{
${ }^{1}$ Tradução Almeida (1977:61)

${ }^{2}$ Segundo Hollenberg (1991:187).

${ }^{3}$ Conforme Almeida (1977:309).

${ }^{4}$ A partícula relativadora hebraica substitui o pronome relativo. Hollenberg (1991: 49).
} 
d4 - utilizado como elemento morfológico para acompanhar uma raiz verbal indicando o infinitivo ou para formar o gerúndio. Exemplo: rmal = dizer/dizendo, mas pode acompanhar o infinitivo, após um verbo conjugado, para completar seu conceito. Exemplo: twX[1 1xh = comece a fazer.

e - Min !m indica direção: para fora de, para longe de, além de. Exemplo: [h-!m Wacy $=\left(\right.$ uns) saíram para fora do povo ${ }^{1}$. Ele aparece abundantemente na forma prefixal e pode ser utilizado para formar o comparativo ${ }^{2}$, Exemplo: $\sim\left[\mathrm{h}-1 \mathrm{~km}^{3} \mathrm{hbg}=\right.$ maior do que todo o povo. Além dessas, podemos notar ainda outras possibilidades, como: e1 - Locativo. Exemplo: lyzrbm = do Brasil; e2 - Causal. Exemplo: Wny[Xpm = por causa das nossas transgressões, em Isaías 53:5. e3 - Temporal, no sentido de desde. Exemplo: $\sim \mathrm{yrw}[\mathrm{nm}=$ desde a juventude. e4 - A partícula de exceção, como $\sim$ Wmm = sem mácula em Jó 11:15 (devemos lembrar que a rigor sua tradução é "para fora da mácula").

e5 - O locativo de anterioridade. Exemplo: $1[$ = sobre, portanto $1[\mathrm{~m}=$ além de, no sentido de anterioridade será "acima", o mesmo ocorrendo com seu oposto, pois txt = sob e, portanto, txtm = aquém, no sentido de anterioridade será "abaixo".

f - Sche X é outra partícula inseparável com função bem definida. É o pronome relativo hebraico utilizado como redução da partícula relativadora $\mathrm{rXa}$, principalmente nos escritos mais modernos. Exemplo: wrmayX bXwx yna = eu penso que eles dirão.

g - He h é a partícula inseparável que se apresenta com duas funções ao prefixar palavras: g1 - O artigo, entendido como definido em virtude do seu caráter demonstrativo ${ }^{4}$, claramente

\footnotetext{
1 "Saíram do povo", em Êxodo 16:27. Conforme Almeida (1977: 73).

${ }^{2}$ Observe que o "!" final é assimilado e o Yod vocálico deixa de aparecer. Hollenberg (1991: 155).

${ }^{3}$ Conforme Hollenberg (1991: 173).

${ }^{4}$ Conforme Hollenberg (1991: 50).
} 
observado na palavra $\sim$ wyh $=$ hoje, uma vez que é constituída pela palavra $\sim$ wy $=$ dia mais o artigo definido h, resultando "este dia" ou hoje. Além disso, ele prefixa o adjetivo quando no seu uso atributivo, ou seja, caracterizando o substantivo ${ }^{1}$. Exemplo: hbwjh $\mathrm{hXyah}=\mathrm{a}$ mulher boa.

g2 - O interrogativo, embora algumas vezes possa ser omitido (deixando a cargo do contexto sua explicação), aparece prefixando a palavra questionada. Exemplo: $\mathrm{wl} \sim \mathrm{WlXh}=$ ele está passando bem? ou, ele está em paz?

Além destes prefixos, ainda podemos apresentar os preformativos t e $\mathrm{y}$, que aparecem junto de raízes distintas para formar novos significados. Exemplo: dymlt $=$ aluno, da raiz $\mathrm{dml}=$ aprender/ensinar (o y sai da raiz porque é vocálico). Já o preformativo y geralmente é utilizado para nomes próprios. Exemplo: bq[y = Jacó, do substantivo bq[ = calcanhar.

\subsection{Os Afixos Como Elementos de Coesão Textual}

Estabelecemos a lingüística textual como campo de atuação dos elementos, objeto da nossa investigação, para chegarmos, por redução, aos prefixos e sufixos hebraicos originados, embora não unicamente, nos pronomes como ponto de partida. Isso porque pretendemos constituir a base da nossa investigação nesses elementos, uma vez que os apreciamos como um dos responsáveis pela coesão textual hebraica.

Observemos a definição de coesão apresentada,

Compreende todos os processos de seqüencialização que asseguram uma ligação lingüística significativa entre os elementos que ocorrem na superfície textual. A coesão se dá por meio de mecanismos encadeadores. Estes mecanismos são responsáveis pela recuperação de uma seqüência lingüística, ou seja, responsáveis pelos mecanismos de referência. A coesão é linear e se dá na superfície do texto. Constitui-se de unidades lingüísticas explícitas no texto.

Sitya (1995: 71)

\footnotetext{
${ }^{1}$ Segundo Neto (1997: 245).
} 
Koch (1991:17) vai além com a definição e apresenta a classificação do elemento catafórico (aquele que remete a toda seqüência do texto) e do elemento anafórico (aquele que remete ao enunciado anterior), além de outros mecanismos com função de assinalar determinadas relações de sentido entre enunciados ou parte deles, variando de oposição ou contraste, finalidade ou meta, conseqüência, localização temporal, e até adição de argumentos ou idéias, por meio dos quais ocorre a tessitura do texto (elemento que faz o texto funcionar como unidade em seu ambiente, ocorrendo uma ligação cognitiva ${ }^{1}$ entre os elementos que se estabelecem na superfície ${ }^{2}$ textual. Sitya (1995: 68).

Koch propõe duas grandes modalidades de coesão textual, a coesão referencial e a coesão seqüencial, baseando-se nos estudos sobre a coesão do Inglês, mais especificamente na obra de Halliday \& Hasan $^{3}$ que demonstra cinco mecanismos funcionais da construção da textualidade denominados: referência (pessoal, demonstrativa, comparativa), substituição (nominal, verbal, frasal), elipse (nominal, verbal, frasal), conjunção (aditiva, adversativa, causal, temporal, continuativa) e coesão lexical (repetição, sinonímia, hiperonímia, uso de nomes genéricos, colocação).

Sabendo que os diversos tipos de relações semânticas e/ou pragmáticas estabelecidas entre segmentos do texto durante sua progressão textual ocorrem por meio de procedimentos lingüísticos, denominados coesão seqüencial ou seqüenciação ${ }^{4}$, podemos de imediato descartar sua possibilidade de ocorrência entre os afixos do hebraico. Neste caso, nosso foco analítico será a coesão referencial.

A coesão referencial ficou definida como aquela em que um componente da superfície do texto (forma referencial ou remissiva) faz remissão a outro(s) elemento(s) do universo textual (elementos de referência ou referente textual).

\footnotetext{
${ }_{1}^{1}$ Cognitiva: ligação de significado compreensível.

2 Superfície textual: palavras e frases que compõem um texto. Koch (1991: 18).

${ }^{3}$ A citação é de Koch (1991:19), sobre Halliday, M.A.K. \& Hasan, R. Coesion en English London, Longman, 1976.

${ }^{4}$ Definição apresentada por Koch (1991: 49).
} 
De acordo com essa definição, podemos observar a amplitude de elementos capazes de executar essa remissão. Esses elementos podem ser estudados de acordo com sua classificação gramatical relacionada ao comportamento funcional no texto.

Quando Koch observa que as formas pronominais não remetem a nenhum elemento particular do texto, mas ao contexto ou parte dele, precedente ou subseqüente, como um todo, esclarece que as formas remissivas não referenciais são aquelas que não fornecem instruções de sentido, mas sim de conexão, podendo ser presas ou livres.

As formas remissivas não referenciais ${ }^{1}$ presas apresentam, em linhas gerais, os determinantes da gramática estrutural e gerativa: os artigos, os pronomes adjetivos (demonstrativos, possessivos, indefinidos, interrogativos) e os numerais cardinais e ordinais, quando acompanhados de nomes, além dos pronomes pessoais de primeira e segunda pessoas (eu, tu, você, nós, vós, vocês) que se prendem a elementos situacionais ${ }^{2}$. Enquanto que as formas remissivas não referenciais livres estariam entre os pronomes pessoais de terceira pessoa (ele, ela, eles, elas) e os pronomes substantivos em geral (demonstrativos, possessivos, etc.) que têm função pronominal propriamente dita, bem como os advérbios pronominais do tipo lá, aí, ali, acima etc.

Essas modalidades constituem formas remissivas não referenciais porque não fornecem instruções de sentido. As formas remissivas referenciais estariam entre os grupos nominais definidos, pois além de fornecerem, em grande número de casos, instruções de concordância, fornecem também instruções de sentido, ou seja, fazem referência a algo no mundo extralingüístico.

As formas remissivas referenciais remetem a significados do mundo extralingüístico, ao contrário das formas remissivas não referenciais que remetem a significados dentro dos limites textuais. Na língua hebraica, essas formas se apresentam abundantemente numa estrutura afixada.

\footnotetext{
${ }^{1}$ Referência, nesse caso, diz respeito à tradição semântica, a qual designa a relação estabelecida entre uma forma lingüística e o seu referente extralingüístico.

${ }^{2}$ Koch (1991: 33).
} 
Sendo assim, podemos apresentar os afixos como recursos da coesão textual hebraica, já que aparecem nos textos identificados como elementos da língua, cuja função precípua é estabelecer suas relações textuais ${ }^{1}$.

Examinando exemplos no texto da Bíblia Hebraica poderemos analisar esses afixos aplicados como recursos de coesão referencial, ou seja, aqueles que se anexam às raízes para construir uma conexão textual, e não aqueles afixos que são anexados com a finalidade de formar uma nova palavra, pois, neste caso, transforma-se em afixo permanente (preformativos e aformativos) para fornecer um novo significado.

Mesmo que o afixo (elemento de coesão) modifique diretamente o seu termo regente, ele fará referência a algo do universo textual e não a do universo extralingüístico, ocorrendo, neste caso, a coesão referencial. Apesar desse afixo ser o elemento responsável por esta coesão, deverá ser entendido por forma remissiva não referencial.

\subsubsection{Forma Remissiva Não Referencial Presa ("Função Artigo" ${ }^{2}$ )}

A denominação das formas remissivas não-referenciais presas ${ }^{3}$ foi utilizada por Koch, que sugeriu entender a palavra "remissiva" como sinônima da palavra "referencial", utilizada por Halliday, com a finalidade de indicar a relação de sentido estabelecida na superfície textual, apesar de ela pretender usar o termo "não referencial" para indicar a ausência de um referente extralingüístico a que esta forma "remissiva" se relacionasse, portanto, "presa" ao nome (ou sintagma nominal) relacionado, pois este apresenta um referente extralingüístico.

Deste ponto surge, então, uma definição: são formas relacionadas a um nome concordando em gênero e/ou número, antecedendo-o, bem como ao(s) seu(s) possível(is) modificador(es) de nome dentro de um grupo nominal exercendo "função artigo". Exemplo: $O$ Eterno visitará Jacó em seus caminhos e conforme seus feitos lhe retribuirá ${ }^{4}$. Os pronomes grafados estão fazendo remissão à idéia anterior do texto, além de cumprir a função artigo.

\footnotetext{
${ }^{1}$ Koch (1991: 16).

${ }^{2}$ A função artigo ocorre quando um termo passa a pertencer ao paradigma articular funcionalmente definido. Koch (1991: 34).

${ }^{3}$ Conforme Koch (1991: 34).

${ }^{4}$ Versão composta por Melamed (1980: 380).
} 
Assim, observamos que no original hebraico ${ }^{1}$ : wyll[mk wykrdk bq[y-l[ dqpy hwhy wl byXy, principalmente em relação aos afixos, a definição não é funcional. Isso porque, na língua hebraica, tais formas são afixadas ao nome (termo regente) e devem concordar em gênero e número com o seu referente. Por isso, o sufixo wy concorda, neste caso, com seu outro igual da palavra anterior (lembrando que o texto hebraico é escrito da direita para a esquerda) e não com o termo regente.

\subsection{1a. Artigos Definidos e Indefinidos}

Em língua portuguesa, os artigos definidos se apresentam como: o, a, os, as, funcionando como anafóricos e os indefinidos um, uma, uns, umas, funcionando como catafóricos, porém, no hebraico, sua ocorrência será através de um afixo com uso prefixado para expressões definidas e inferido do contexto para expressões não definidas.

Primeiramente observemos que o artigo definido do hebraico nunca aparece como palavra autônoma, mas sempre afixada ao nome, funcionando como anafórico, apesar de manter seu caráter demonstrativo $(\sim \text { Wyh }=\text { "o dia" /hoje, este dia })^{2}$. Como na expressão: $\sim[$ ph, cujo significado é "a vez"(atual), esta vez, o que não contradiz a definição, visto que os pronomes adjetivos demonstrativos também exercem a "função artigo"

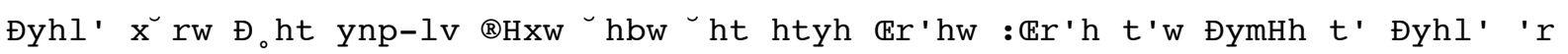

b tyH'rb
: Đymh ynp-lv tpxrm

"No princípio criou Deus os céus e a terra. E a terra era sem forma e vazia; e havia trevas sobre a face do abismo; e o Espírito de Deus se movia sobre a face das águas ${ }^{5} . "$

Neste exemplo (os céus e a terra), notamos que o artigo definido hebraico é invariável quanto à forma, sua tradução acompanha sempre o gênero e o número do seu referente "os céus"/ "a terra" e é anafórico, e remete a elementos de conhecimento prévio, culturalmente

\footnotetext{
${ }^{1}$ Original apresentado por Melamed (1980: 380).

${ }^{2}$ Conforme Hollenberg (1991: 50).

${ }^{3}$ Segundo indica Koch (1991: 35) de acordo com a divisão de Kallmeyer et al, 1974.

${ }^{4} \mathrm{O}$ sinal : indica o ponto final da frase hebraica.

${ }^{5}$ Tradução Almeida (1977: 03).
} 
compartilhado entre o escritor e os seus leitores, portanto, é entendido como artigo ${ }^{1}$.

De qualquer forma, na expressão assinalada \#rahw, o exemplo mostra bem mais claro a função anafórica do artigo definido, e a terra, aquela criada por Deus, anteriormente mencionada no texto. Mesmo que a partícula $h$ não apresente tão claramente sua função, podemos deduzi-la pelo contexto através de inferências, quando então observaremos sua função como artigo definido ou pronome adjetivo demonstrativo ou ainda outras funções que, porventura, possa assumir, mas certamente quando artigo definido será uma forma remissiva não referencial e, sobretudo, um elemento de coesão textual.

Quanto ao indefinido observe o exemplo: $\sim \mathrm{ymh}$ \$wtb [yqr yhy $\sim$ yhla rmayw = "E Elohim disse: haja (uma)expansão no meio das águas." (Gênesis 01:06)

Neste caso, não existe no hebraico um elemento de coesão (forma remissiva) a partir do indefinido, mas sim da sua própria inexistência e/ou ausência do artigo definido (ou outro determinante $^{2}$ ), que mostrará para o leitor/falante a indefinição do termo. Portanto, dentro do óbvio, será indeterminado um nome qualquer quando não estiver acompanhado da partícula definidora $\mathrm{h}$ ou de outro definidor e, a esta indeterminação inferida do contexto (presença do indefinido pela ausência de definidor), chamaríamos forma remissiva não referencial presa e, mesmo não sendo aceito como nomenclatura válida, é sem dúvida, no caso da língua hebraica, uma característica de coesão textual.

\subsection{1b. Pronomes Adjetivos}

Os pronomes adjetivos são relativamente fáceis de identificar, uma vez que se encontram claramente explicitados nos textos, segundo conceituados:

...Há pronomes que acompanham os substantivos, a fim de caracterizá-los ou determiná-los, atuando em funções típicas dos adjetivos. São,

\footnotetext{
${ }^{1}$ De acordo com a "Teoria do Artigo" de Weinrich (1971,1973).

${ }^{2}$ Um nome hebraico é determinado: 1) como nome próprio; 2) pelo artigo; 3) pelo sufixo; 4) por um genitivo determinado subseqüente. Hollenberg (1991: 115).
} 
justamente por isso, chamados pronomes adjetivos.

(Pasquale Cipro Neto, 1997)

Estes pronomes adjetivos ${ }^{1}$ podem ter correspondentes afixos no hebraico, conforme abaixo:

\subsection{1b1. Pronomes Adjetivos Demonstrativos}

Quanto aos demonstrativos, cuja função é indicar a posição dos seres designados em relação às pessoas do discurso, situando-as no espaço, no tempo ou no próprio discurso ${ }^{2}$, Koch apresentou para a língua portuguesa este, esse, aquele, tal, mas normalmente o hebraico possui apenas um pronome demonstrativo hz (este/esse), taz (esta/essa) e hla (estes/estas// esses/essas) que aparece nos textos com uma peculiaridade no mínimo interessante: segue acompanhando, obrigatoriamente, em textos mais antigos, o artigo definido " h". Além disso, admite ainda o uso dos pronomes pessoais da terceira pessoa !h(elas), $\mathrm{h}(\mathrm{eles})$, ayh(ela), aWh(ele), como demonstrativos quando se reporta a algo anteriormente dito, mas sempre na qualidade de adjetivo atributivo, ou seja, após seu substantivo, desde que prefixados com a partícula $"$ h ${ }^{3}{ }^{3}$. Exemplo:

\section{'bhZh v-rva hlywxh \#ra-lK ta bbSh aWh !AvyP dxah v $`$ hVh ! baw xldBh $\sim \mathrm{V}$ bAj awhih \#rah bhzW}

“O nome do primeiro é Pischon, este é o que rodeia toda a terra de Hakhawilá, onde há ouro. E o ouro daquela terra é bom, ali há o bdélio e a pedra sardônica." ${ }^{4,}$

O importante a ser observado nesse exemplo é a função do pronome pessoal de terceira pessoa feminino como pronome adjetivo demonstrativo e, diante disto, chamo a atenção ao fato de que, tanto neste caso como nos casos em que temos a real presença do demonstrativo hebraico (hla taz hz) quando apresentarem uso atributivo, exigirá a presença

\footnotetext{
${ }^{1}$ De acordo com a divisão de Kallmeyer et al, 1974. Koch (1991: 35-36).

${ }^{2}$ Conforme Neto (1997: 289).

${ }^{3}$ Conforme Hollenberg (1991: 47).

${ }^{4}$ Tradução Almeida (1977: 04)
} 
do artigo definido, o prefixo " $h$ ", que, além de acentuar sua função artigo, ainda valoriza o afixo como forma remissiva não referencial presa. Isso o caracteriza, indubitavelmente, como um elemento de coesão textual, tanto como artigo definido, quanto como prefixo do pronome adjetivo demonstrativo.

\subsection{1b2 Pronomes Adjetivos Possessivos}

Koch apresenta como formas remissivas não referenciais presas os pronomes adjetivos possessivos da língua portuguesa (os que fazem referência às pessoas do discurso, atribuindolhes a posse de algo ${ }^{1}$ ) meu, teu, seu, nosso, vosso, dele (também seus femininos e plurais).

No caso da língua hebraica, não poderíamos apresentar algumas palavras indicativas de posse como acima a não ser aquelas formadas a partir da preposição $1 \mathrm{X}$ (de) com os sufixos pronominais correspondentes $(! \mathrm{hlX} \sim \mathrm{hlX} ! \mathrm{klX} \sim \mathrm{klX}$ wnlX hlX wlX $\$ 1 \mathrm{X}$ $\mathrm{ylX},{ }^{2}$ porém, literalmente significam: de mim, de ti, de ele, de ela, de nós, de vós, de vós/feminino, e de eles, de elas), assim sendo a partícula $1 X$ (de) permanece como preposição. Embora seja uma preposição com característica possessiva assume a função de termo regente ${ }^{3}$ para receber os sufixos de flexão pronominal, que se constituem como sufixos possessivos da língua hebraica.

Os pronomes ou sufixos possessivos hebraicos serão sempre dependentes das palavras que representam a posse, ou seja, o objeto possuído, porque são sufixos que nelas se apóiam. Essas palavras ou raízes, funcionam como termo regente em que se fixam tais sufixos pronominais e estes se formam a partir da redução drástica dos pronomes pessoais, conforme apresentado no quadro abaixo. São formas abreviadas dos pronomes pessoais que assumem função de pronome possessivo no nome, bem como função de pronome oblíquo no verbo.

Tabela 6 Quadro Contrastivo dos Pronomes Sufixos e Pessoais do Hebraico com o Português

\footnotetext{
${ }^{1}$ Conforme NETO (1997: 288).

${ }^{2}$ A ordem aqui corresponde à da escrita hebraica, ou seja, da direita para a esquerda.

${ }^{3}$ Conforme HOLLENGERG (1991: 46).
} 


\begin{tabular}{|c|c|c|c|}
\hline \multicolumn{2}{|c|}{ PRONOMES PESSOAIS } & \multicolumn{2}{|c|}{ SUFIXOS PRONOMINAIS } \\
\hline Português & Hebraico & Oblíquo & Possessivo \\
\hline Eu(comum) & $\begin{array}{r}\text { ykinoa }] / y \\
n \text { ia }]\end{array}$ & YRaiz & YRaiz \\
\hline $\mathrm{Tu}(\mathrm{masc})$. & hT'a; & $\wedge_{\text {Raiz }}$ & $\wedge_{\text {Raiz }}$ \\
\hline Tu(fem.) & T.a & \%Raiz & $\%$ Raiz \\
\hline Ele & aWh & WRaiz & WRaiz \\
\hline Ela & ayhi & $\mathrm{H}^{\prime}$ 'Raiz & $\mathrm{H}^{\prime}$ 'Raiz \\
\hline Nós(comum) & Wnx.n'a] & WnRaiz & WnRaiz \\
\hline Vós(masc.) & $\sim \mathrm{T}, \mathrm{a}$ & $\sim \mathrm{K}$, Raiz & $\sim \mathrm{K}$, Raiz \\
\hline Vós(fem.) & (hn')!t,a; & !k,Raiz & !k,Raiz \\
\hline Eles & $\sim \mathrm{h}$ & $(\sim) \sim$ h, Raiz & $(\sim) \sim$ h, Raiz \\
\hline Elas & (hn')!h, & (!)!h,Raiz & (!)!h,Raiz \\
\hline
\end{tabular}

Observe que os sufixos pronominais de variação mais acentuada, tanto no masculino como no feminino, encontram-se na segunda pessoa quando o $t(\mathrm{t})$ se transforma em $k h^{1}\left(\$^{2}\right)$. Além disso, apesar de o objetivo da pesquisa excluir a sonoridade vocálica como diferenciador semântico, porque se interessa exclusivamente pelo hebraico consonantal e pretende enfocar mais o campo visual do texto escrito, relevamos informar que o gênero destes sufixos, quando em textos não vocalizados, necessita ser intuído do contexto, o que não ocorre nos textos bíblicos massoréticos, porque são vocalizados e diferenciam o feminino $(\%=k h)$ do masculino $\left({ }^{\wedge}=k h a\right)$ através da vogal. Isso faz da sonoridade vocálica um elemento de grande importância na determinação de significados, mas não a impede de ser estudada cuidadosamente em período posterior.

Quanto às formas plurais, os sufixos pronominais determinante são o "m" $(\sim$, forma

\footnotetext{
1 "kh" É lido aspirado como o "J" espanhol, segundo transliteração oficial apresentada por Berenzzin (1995: 43).

${ }^{2}$ A forma (\$) é a forma da consoante (k) que se modifica em final de palavras, conforme Hollenberg (1991: $03)$.
} 
final $^{1}$ ) para palavras masculinas e o $n\left(\right.$ !, forma final $\left.{ }^{1}\right)$ para palavras femininas, porém, devemos lembrar que no caso de segunda pessoa o " $\$ 1$ " retorna à sua forma original " $\mathbf{k}$ " para receber o sufixo e, na terceira pessoa pode aparecer um "h" precedendo o sufixo $(\sim \text { ou ! })^{1}$ para ajudar a esclarecer a raiz como terceira pessoa.

Entretanto, em todos os casos, esses sufixos não passam de formas fortemente reduzidas dos pronomes pessoais com função de pronomes oblíquos ou possessivos, como no exemplo seguinte, traduzido na língua portuguesa: Gênesis 1:24 (dk `a tyXarb)

'!k-yhyw Hnyml \#ra-wtyx Xmrw hmhb Hnyml hyx Xpn \#rah acwt $\sim$ yhla rmayw

"E disse Deus: produza a terra alma vivente de sua espécie; gado e répteis, e bestas feras da terra conforme a sua espécie. E assim foi” ${ }^{2}$.

O possessivo observado na tradução é um determinante exatamente igual ao original hebraico, a única diferença é sua forma de ocorrência, objeto da nossa análise, que acontece em virtude da presença de um afixo. Na realidade, é o sufixo de terceira pessoa do feminino "h" - funcionando como o possessivo sua/dela - acrescentado à raiz "!ym" - o substantivo espécie - , que, somados, formam "Hnym", cujo significado se traduz por sua espécie.

Concluímos então que o sufixo pronominal feminino " h" e, por extensão, os demais sufixos pronominais quando usados como pronome adjetivo possessivo são uma forma remissiva não referencial presa, ou seja, um elemento de coesão textual do Hebraico.

\subsection{1b3. Pronomes Adjetivos Indefinidos}

Segundo a divisão adotada por Koch agora apresentaríamos os pronomes indefinidos que se referem à terceira pessoa do discurso de forma vaga, imprecisa ou genérica ${ }^{3}$, com função adjetiva (como: algum, todo, outro, vários, diversos etc.), que ocorrem no hebraico

\footnotetext{
${ }^{1} \mathrm{O}$ hebraico apresenta estas formas consonantais diferenciadas quando em final de palavra.

${ }^{2}$ Tradução Almeida (1977: 03).

${ }^{3}$ Segundo Neto (1997: 296).
} 
através de seus correspondentes. Entretanto, não encontramos formas afixas, objetos desta pesquisa, para tais indefinidos, motivo pelo qual analisaremos os interrogativos.

\subsection{1b4. Pronomes Adjetivos Interrogativos}

Os pronomes interrogativos do português, que e qual, têm correspondentes hebraicos funcionando da mesma forma que esses, porém, além deles o hebraico apresenta um afixo como interrogativo.

$\mathrm{O}$ "h" interrogativo funciona no texto hebraico como uma partícula adverbial afixada no início da palavra questionada, exemplo: $\mathrm{wl} \sim \mathrm{lvh}=$ "ele está passando bem? ${ }^{\prime}{ }^{1}$. Essa partícula é considerada advérbio, pois, ao questionar um nome, embute a conjugação dos verbos ser/estar/ter, conforme foi apresentado no exemplo acima. Quando acompanhado de um verbo para questioná-lo, modifica-o, questionando a ação que este representa. Por exemplo, o verbo tkll (ir), conjugado na primeira pessoa do inconcluso, é \$la = eu irei, mas, se estiver sendo questionado $\$$ lah = "irei eu?", a presença do prefixo apenas modifica o verbo, questionando a ação.

Apesar disso, a partícula não deixa de caracterizar o nome, no mínimo não deixa de acompanhá-lo, modificando-o, e esse é o nosso ponto de interesse. Uma vez que esta partícula "h" acompanha o nome, modificando-o, pode ser entendida como uma forma remissiva não referencial presa, um elemento de coesão textual hebraico.

\subsection{1b5. Pronome Adjetivo Relativo}

O hebraico utiliza a partícula relativadora $\mathrm{rXa}$ (aschér) nos textos bíblicos mais antigos, porém, em textos mais recentes, notamos o uso da partícula prefixa " X" exercendo a função de pronome relativo, substituindo-a quase que por completo. Exemplo:

" ...brl yh tpX-1[v lwxk rpsm !ya hylmglw..." = "e eram inumeráveis os seus

\footnotetext{
${ }^{1}$ Segundo Hollenberg (1991: 153).
} 
camelos, como a areia que há na praia do mar em multidão"1. Nesse caso, o prefixo $\mathrm{V}$ pronome relativo deve ser entendido como uma forma remissiva não referencial presa, um elemento de coesão textual hebraico.

\subsection{1c. Os Numerais (Cardinais e Ordinais)}

Koch entende que os numerais podem exercer a função artigo ao acompanhar um nome dentro de um sintagma nominal e, neste caso, funcionaria como forma remissiva não referencial presa. Exemplo:

\section{'dxa $\sim$ Ay rqb-yhyw br[-yhyw hlyl arq \%vxlw $\sim$ Ay rAal $\sim$ yhla arqYw}

"E Deus chamou à luz dia; e às trevas chamou noite. E foi a tarde e a manhã do dia primeiro ${ }^{2} . "$

\subsubsection{Forma Remissiva Não Referencial Livre}

As formas não-referenciais livres são aquelas que não acompanham um nome dentro de um grupo nominal, mas que são utilizadas para fazer remissão, anafórica ou cataforicamente, a um ou mais constituintes do universo textual.

(Ingedore Villaça Koch, 1991)

É evidente que os pronomes adjetivos serão os elementos essencias da forma remissiva não referencial presa, visto que sua função é acompanhar o substantivo. Do mesmo modo, os elementos essencias da forma remissiva não referencial livre podem ser observados como oposição fundamental às formas presas nos pronomes substantivos, pois estes substituem os substantivos de referência.

\subsubsection{Os Pronomes Pessoais de Terceira Pessoa: Ele, Ela, Eles, Elas}

Koch (1991) apresenta em primeiro lugar os pronomes pessoais de terceira pessoa (ele, ela, eles, elas), funcionando como anafóricos. Se observarmos o exemplo seguinte, composto a partir das frases da própria Koch, perceberemos claramente o funcionamento desses pronomes: "O juiz condenou o réu $\mathbf{b}^{\mathbf{b}}$ a dez anos de prisão. Ele achou a pena condizente com o ato criminoso. Mas ele $\mathrm{b}^{\mathbf{b}}$ não se conforma com o rigor da pena".

\footnotetext{
${ }^{1}$ Tradução Almeida (1977: 260).

${ }^{2}$ Gênesis 01: 5 - Tradução Almeida (1977: 03).
} 
Observando a correspondência das letras sobrescritas no exemplo, reconhecemos o elemento de referência por ele preencher as condições de concordância com o pronome. O mesmo deve ocorrer com os pronomes hebraicos que podem aparecer na forma livre ou sufixal. Observemos o exemplo:

\section{Avlv lAmtK AM[ WNnya hNhw !bl ynP-ta bq[y arYw}

"Viu também Jacó o rosto de Labão e eis que não era para com ele como dantes ${ }^{1}$."

Conforme a tradução apresentada, o exemplo hebraico esclarece a possibilidade do uso do pronome sufixo de terceira pessoa como o pronome pessoal que retoma Jacó como elemento de referência, o que nos conduz a aceitar os pronomes sufixos de terceira pessoa como elementos de coesão de texto.

\subsubsection{Os Pronomes Substantivos}

Pronomes substantivos são aqueles que ocupam o lugar dos substantivos de uma determinada frase. Se os pronomes adjetivos acompanham o substantivo e os pronomes substantivos os substituem, nada impede que sejam representados pelos mesmos pronomes utilizados em um ou em outro caso. Conforme observamos, tais pronomes ocorrem na forma adjetiva ou adverbial. Portanto, os pronomes demonstrativos e indefinidos não poderão se apresentar numa forma afixa entendida por forma remissiva não referencial livre.

\subsubsection{2a. Os Pronomes Substantivos Possessivos.}

$\mathrm{Na}$ língua portuguesa, tais pronomes deverão deixar claro que substituem o substantivo, por isso é apresentado da forma que segue: (o) meu, (o) teu, (o) seu, (o) nosso, (o) vosso, (o) dele, e seus femininos. Porém, no hebraico o pronome possessivo é exclusivamente sufixo, portanto, dependente do nome regente e, nesse caso, não poderia substituí-lo. Para resolver esta questão, o hebraico utiliza estes pronomes funcionando como objeto, aplicado na partícula indicativa do acusativo (objeto direto) ta, diretamente no verbo

transitivo direto ou na partícula indicativa do dativo (objeto indireto) 1 , que poderão ser utilizados como pronomes substantivos quando necessário. Por exemplo: 


\section{`hllxTw hyl[ Tpnh ^Brx yK tyzG !hta hnbt-al yL-hf[T ynba} $\mathrm{xBzm}-\sim$ aw

"E se me fizeres um altar de pedras, não o farás de pedras lavradas: se sobre ele levantares o teu buril, profaná-lo-ás ${ }^{2} . "$

Embora possamos observar nessa tradução uma inversão no referente textual, sua função não fica prejudicada, pois o pronome !hta não se refere ao altar - conforme ela apresenta - porque aparece na forma feminina plural, cuja correspondência seria o substantivo "pedras".

\subsubsection{2b. Os Pronomes Substantivos Interrogativos e Relativos}

O pronome interrogativo afixo hebraico, já abordado nesta pesquisa, é o $\mathrm{h}$ prefixado nos termos questionados, mas ele é reconhecido como uma partícula adverbial que questiona o termo regente e, portanto, não assume forma do pronome substantivo. A mesma ocorrência é observada no prefixo que representa o pronome relativo $\mathrm{V}$, embora este não seja uma partícula adverbial.

\subsubsection{Os Numerais}

É normal o uso de numerais cardinais, ordinais, multiplicativos e fracionários para substituir substantivos, tanto na língua portuguesa como na língua hebraica. No hebraico, podemos demonstrar sua utilização conforme o exemplo seguinte, porém não é possível sua existência na forma afixa e remissiva não referencial livre. Exemplo:

\section{!ybW rd[ !yB WmyfT xwrw ynpl Wrb[ wydb[-la rmaYw ADbl rd[ rd[ wydb[-dyB !TYw... ymlW \%lt hnaw hTa-yml rmal $\wedge^{\wedge}$ lavw yxa wf[ ${ }^{\wedge}$ vGpy yK rmal !Avarh- ta wcyw `rd[}

\footnotetext{
${ }^{1}$ Gênesis 29: 2 - Tradução Almeida (1977: 03).

2 Êxodo 20:25 - Tradução Almeida (1969: 77).
} 
`ynpl hLa

“...E deu-o na mão dos seus servos, cada rebanho à parte, e disse a seus servos: Passai adiante da minha face e ponde espaço entre rebanho e rebanho. E ordenou ao primeiro, dizendo: Quando Esaú, meu irmão, te encontrar e te perguntar, dizendo: De quem és, para onde vais, de quem são estes diante da tua face ${ }^{1}$ ?"

\footnotetext{
${ }^{1}$ Gênesis 32:16 e 17 - Tradução Almeida (1969: 35).
} 


\section{O ENSINO DO HEBRAICO, LÍNGUA ESTRANGEIRA, A PARTIR DOS AFIXOS - FOCO NA FORMA.}

Os fenícios são os precursores da escrita alfabética, cujos signos os hebreus emprestaram para formar sua escrita, seguido pelos gregos que a importaram destes. $\mathrm{O}$ marcador da primeira letra hebraica, @1a (alef), cujo som glotal não existia na língua grega, foi reproduzido como aleph, transformando-se mais tarde em alpha para representar a vogal " $a$ ", primeira letra do alfabeto grego; e tyb(beyt), a segunda letra do alfabeto hebraico, transformou-se em beta por semelhança fônica, o que deu origem à palavra grega alfabet (a), "alfabeto". Sabendo disso, Martinet conclui que a grande maioria dos alfabetos ocorre como variantes resultantes da adaptação de outros sistemas fonológicos (sonoro). Assim, a escrita alfabética se opõe ao nível da aprendizagem e da identificação de formas não encontradas até então, mas poderá ser identificada a qualquer tempo pelo aprendiz através da equivalência destas realidades fônicas em que a aquisição do significado de uma palavra pode se dar pelo contexto, e sua forma gráfica associada sem a intervenção de nenhum professor a partir do sistema de equivalência de sons (letras anteriormente aprendidas) ${ }^{1}$.

Neste aspecto é necessário saber que a memória imediata não pode captar estruturas sem significado, mesmo que sejam apenas símbolos isolados; portanto, c 1 b não tem significado algum para quem os visualiza mesmo que afirmemos serem letras do alfabeto hebraico. Na verdade, torna-se necessário criar ou representar um valor de significado com importância suficiente para alcançar registro na memória do aprendiz, assunto amplamente apresentado em periódicos, livros - entre os quais alguns aparecem na bibliografia -, resultados de simpósios etc., que serão utilizados oportunamente nesta investigação.

Nestes termos, a metodologia para a aquisição do Hebraico Bíblico a partir dos afixos depende do grau de conhecimento do aprendiz. É necessário que ele tenha, no mínimo, conhecimento pleno do alfabeto para estar capacitado a reconhecer as consoantes hebraicas e compreender o valor que elas têm nos seus diversos usos na língua escrita.

\footnotetext{
${ }^{1}$ Martinet (1995: 118,119)
} 
Na grafia alfabética ocorre a identificação imediata da palavra escrita sem recorrer à análise em fonemas, permitindo a identificação imediata de formas ainda não encontradas, o que reduz de forma decisiva a duração e as dificuldades da aprendizagem da leitura, ${ }^{1}$ desde que se aprendam os fonemas individualmente.

Uma vez que os afixos em questão, quando aprendidos individualmente, carregam a vantagem de possuir significados que podem ser associados à sua sonoridade e, como são representados por uma única consoante ou no máximo duas, eles podem ser identificados de imediato e associados aos seus significados individuais simultaneamente. Em virtude de se apresentarem sempre afixando uma raiz principal com a finalidade de compor a superfície do texto, facilitam a interpretação do significado da mesma e se apresentam claramente definidos. Finalmente, os afixos estão incorporados nos textos (escritos ou falados), os quais podem ser encontrados na vasta literatura hebraica, inclusive na Bíblia, devendo ser estudados no âmbito da lingüística textual.

Quando um determinado leitor pretende compreender um texto qualquer, tanto em língua materna quanto em língua estrangeira, exigir-se-á competência ${ }^{2}$ deste leitor e esta acabará por atribuir ao professor um papel muito importante, uma vez que o consideramos um dos responsáveis no processo de aprendizagem ${ }^{3}$ e de quem esperamos alternativas que facilitem tal aprendizado, além de agilizar o processo para aquisição da competência necessária.

A competência, tanto em língua materna, como em língua estrangeira, exige conhecimento do seu léxico.

O estudo do léxico, enquanto fenômeno lingüístico, faz parte do processo de aquisição de um outro idioma.

(Palomo, 1988)

\footnotetext{
${ }^{1}$ Martinet (1995: 119).

${ }^{2}$ Competência, segundo a lingüística, desenvolve-se através da aquisição ou aprendizagem. Krashen (1982: 1011).

${ }^{3}$ Aprendizagem é processo consciente resultando em competência aprendida ou aprendizado (MAROTE, 1995).
} 
Portanto, tendo em mente as palavras de Basílio

A língua sempre procura atingir o máximo de eficiência, o que se traduz num máximo de flexibilidade em termos de expressão simultaneamente a um mínimo de elementos estocados na memória, cuja flexibilidade nos permite contar com um número gigantesco de elementos básicos de comunicação sem termos que sobrecarregar a memória.

(Basílio, 1989)

Apresentamos um método de ensino que acreditamos utilizar elementos chaves com a flexibilidade necessária para serem reutilizados em vários contextos.

Tal método marca seu ponto de partida no estudo lexical, comumente entendido como aquisição de vocabulário, mas na verdade este conceito admite um sentido bem mais amplo, ou seja, a base para garantir as possibilidades do falar, ler e escrever além de conduzir o falante à posterior compreensão de um vocabulário específico de língua literária, à adequação do vocábulo à expressão de ordem estética e à percepção ou distinção do significado e do sentido $^{1}$ para a compreensão do texto.

Visto que a língua hebraica repete em grande escala as mesmas consoantes iniciais e/ou finais nas palavras de um texto qualquer, funcionando como afixos, concordamos com a afirmação de Basílio há pouco citada, pois contamos com um número ilimitado de unidades significativas para o aprendizado sem sobrecarregar a memória. Nossa análise aponta para esta possibilidade na significação dos afixos, porque eles são formados por consoantes, uma vez que esta língua é de escrita tipicamente consonantal (MARTINET, 1995).

As consoantes que se repetem são consoantes afixas em raízes básicas, independentes daquelas que se apresentam na construção das palavras novas, oriundas de uma raiz acrescida por um prefixo ou sufixo, como o caso dos substantivos da língua portuguesa que se formaram a partir do sufixo ada, acrescentado a outros substantivos, como exemplo o substantivo punhal, acrescido do sufixo ada formou o substantivo punhalada ${ }^{2}$, ou, no próprio

\footnotetext{
${ }^{1}$ Conforme Vilela (1979: 39-42).

${ }^{2}$ Conforme Neto (1997).
} 
hebraico, o verbo abrir, a raiz xtp $\left(p t k h^{1}\right)$, acrescida com o prefixo $\mathrm{m}$ (mem) formou o substantivo xtpm ${ }^{2}(m f t k h=$ chave $)$.

Esses afixos do hebraico, diferentemente da maioria das línguas, possuem significados responsáveis pelos processos sintático-semânticos que se estabelecem na superfície textual ${ }^{3}$ e aparecem anexados nas palavras, formadas, na maioria das vezes, por três consoantes radicais principais. Portanto, constroem a superfície do texto hebraico e são responsáveis pela sua coesão, deixando sua coerência, ou seja, a produção e compreensão do texto nos seus aspectos sociais, históricos e culturais a cargo da ordenação das raízes principais.

Isso ocorre porque os afixos que aparecem no texto hebraico, ocupam a posição de pronomes pessoais e oblíquos, artigo definido, pronome relativo e possessivo, além de conjunções e preposições, entre outros elementos, como os responsáveis pela coesão referencial e, deste modo, pertencem ao modelo funcional do discurso, portanto, são denominados pela lingüística textual de elementos de coesão de texto.

Esses elementos de coesão textual não podem ser estudados sem que os vinculemos à gramática do texto, tanto na língua portuguesa como na língua hebraica, para explicá-los e ensiná-los. Se demonstrarmos na seqüência desta pesquisa que o ensino do Hebraico L2/LE pode ser facilitado a partir dos afixos será necessário, tanto para esta demonstração como para o seu ensino, o auxílio de uma abordagem ${ }^{4}$ gramatical.

Nesse caso, podemos entender que o método de ensino utilizado está focado na forma $^{5}$, pois a abordagem gramatical é o próprio ensino com foco na forma, segundo Simões (2004). Porém, a negociação da forma ${ }^{1}$ deve ser feita de acordo com a definição de Long (1994), conforme comportamento de instrução por meio de intervenções pedagógicas que

\footnotetext{
${ }_{1}^{1}$ As consoantes "kh" devem ser lidas como o "j" aspirado do espanhol. (BERENZIN, 1995).

${ }^{2}$ Conforme Holenberg (1991).

${ }^{3}$ Segundo Koch (1991).

${ }^{4}$ Almeida Filho (1993), define abordagem como sendo uma espécie de filosofia, uma força potencial capaz de orientar todas as decisões e ações da operação global de ensinar línguas. (SIMÕES, 2004).

${ }^{5}$ É importante saber que Ortega (2001: 185) afirma: "o ensino de uma forma deve obedecer a um critério, respondendo as questões: Causa o mesmo problema aos estudantes? É passivo de ser aprendido? É útil?’'
} 
busquem dirigir a atenção do aprendiz em integrar a forma e o conteúdo durante o processamento de material lingüístico novo ${ }^{2}$.

\subsection{Apresentação de Um Modelo Prático de Análise}

A apresentação deste modelo metodológico utiliza como base um verso retirado de um texto da Bíblia hebraica. Foi extraído do livro de Gênesis, capítulo um, verso vinte e um.

\section{hnyml ymh WcrX rXa tXmrh hyxh Xpn-lk taw yldgh ynynth-ta $\sim$ yhla arbyw 'Bwj-yk yhla aryw whnyml@nk@w[-1k taw} "E Elohim criou as grandes baleias, e toda alma do animal rastejante que as águas multiplicaram conforme suas espécies; e toda ave de asas conforme sua espécie. E Elohim viu que era bom". 3

As consoantes coloridas, apresentadas no texto hebraico, representam os afixos, cuja presença implica uma precisão textual em conformidade com a tradução apresentada. Além disso, a presença desses símbolos gráficos coloridos representa uma técnica visual para mostrar a intensidade da freqüência de uma mesma forma durante a apresentação de material novo para a leitura ${ }^{4}$.

Veja na transcrição da tradução do verso hebraico para o português a diferença de interpretação do texto, ao desconsiderarmos os significados dos afixos hebraicos, que acompanham as raízes já traduzidas para a língua portuguesa.

Devemos lembrar que o texto hebraico se escreve da direita para a esquerda, portanto, tais afixos aparecerão invertidos nas raízes do texto em português cuja escrita se faz da esquerda para a direita.

\footnotetext{
${ }^{1}$ Negociação da forma reflete os modos como os professores focalizam a forma durante as interações com os alunos em salas de aula comunicativas. Lima (2002: 22-34).

${ }^{2}$ Conforme Ortega (2001: 179).

${ }^{3}$ Tradução Livre.

${ }^{4}$ Manipulación implícita del input. Ortega (2001:188).
} 
"Elohim (yw)criar (h)grande $(\sim \mathrm{y}) \quad$ (h)baleia( $\sim \mathrm{y}), \quad$ (w)toda alma (h)animal (h)rastejante que (h)águas multiplicar(W) (l)espécie( $\sim$ h); (W)toda ave de asas (l)espécie(wh). (W)ver Elohim que é bom.”

Resulta um texto de difícil compreensão, cuja forma prejudica a visualização dos processos de produção e compreensão do mesmo, ou seja, dificulta a interpretação dos fatores lingüísticos, discursivos, cognitivos ou culturais, exigindo uma atenção maior para estabelecer o seu sentido, uma vez que estamos considerando o ponto de vista de um aprendiz do hebraico língua estrangeira.

Porém, apesar desta dificuldade, sabemos que a coerência subjaz ao texto (Sitya, 1995), ou seja, é cognitiva, não linear, portanto, um receptor mesmo que tivesse dificuldade conseguiria observar sua inteligibilidade ou pelo menos inferir o seu sentido. É possível notar no texto utilizado como exemplo apenas a falta dos elementos de conexão: "Elohim criar grande baleia, toda alma animal rastejante que águas multiplicar espécie; toda ave de asas espécie. Ver Elohim que é bom."

Daí pode-se concluir que a ausência dos significados lexicais dos afixos não traduzidos no texto, o que dificulta a compreensão textual, não se constitui necessariamente como elemento determinante da coerência textual do hebraico. $O$ fato dos afixos não serem responsáveis pelo processamento cognitivo do texto nos impulsiona a verificar seus significados na superfície textual, responsável pelas lacunas deixadas em virtude da ausência desses afixos.

Observe inicialmente o prefixo "W", que equivale ao "e" conectivo, embora possua outras funções morfossintáticas bem expressivas, entre as quais encontramos a forma verbal prefixada com "yw"1. Essa forma verbal do gênero masculino, em terceira pessoa do passado, representa um marcador do texto narrativo no hebraico bíblico, portanto, uma vez

\footnotetext{
${ }^{1}$ Denominada, wayyiqtol, conforme Joüon (1993).
} 
conhecida, impedirá que o aprendiz tenha problemas de interpretação durante a tradução. No texto escolhido para modelo metodológico o prefixo "W" aparece aplicado em dois lugares para indicar a forma verbal wayyiqtol e sua tradução, a seguir, aparece grifada:

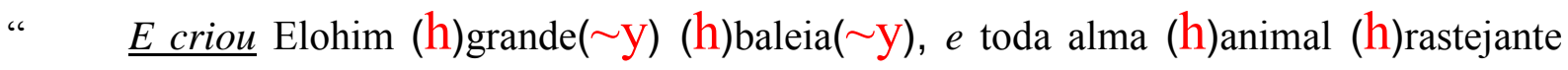
que (h)águas multiplicar(W) (l)espécie( $\sim \mathrm{h}) ; e$ toda ave de asas (l)espécie(wh). $\underline{E \text { viu }}$ Elohim que era bom."

Nesse caso, o prefixo "W" representa o conectivo, e o prefixo que o segue " $\mathrm{y}$ " representará a terceira pessoa do verbo numa conjugação prefixada. Ainda, em oposição a esse " $\mathrm{y}$ " prefixal, temos o "W" sufixal, ou seja, uma forma para representar a flexão da

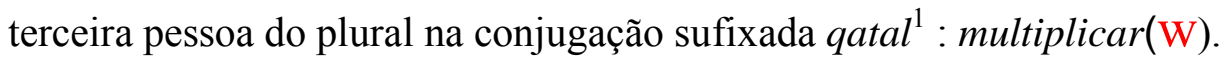

Diante disso, podemos concordar com Hollenberg (1991) que afirma ser por meio dos afixos que ocorrem as flexões dos verbos hebraicos. $\mathrm{O}$ autor denomina a forma prefixada imperfeito e a forma sufixada perfeito, justificando as nomenclaturas por não designarem temporalidade e sim caracterizarem a ação como inconclusa ou conclusa.

Retornando ao texto, na medida em que observamos os resultados da aplicação dos significados apresentados para os afixos, percebemos que o mesmo vai tomando forma em sentido linear até mesmo na conjugação verbal, em grifo no texto, conforme segue:

“ E Elohim criou (h)grande $(\sim \mathrm{y})(\mathrm{h})$ baleia $(\sim \mathrm{y})$, e toda alma (h)animal (h)rastejante que (h)águas multiplicaram (l)espécie( $\sim \mathrm{h})$; e toda ave de asas (l)espécie(wh). E Elohim viu que era bom."

São diversas as implicações dos sufixos hebraicos conforme observamos ao longo desta análise, os quais não se aplicam somente à formação dos verbos, mas também a uma 
série de eventos, tais como os plurais dos nomes masculinos. O sufixo responsável pela formação dos plurais masculinos " $y$ ” também será utilizado para formar o plural dual masculino $^{2}$. O plural dual carrega como marca lingüística sua utilização mais comum em elementos dispostos aos pares na natureza: mãos, olhos, entre outros, bem como termos que designam unidades temporais, dois anos, dois dias etc.

No texto objeto da análise aparece para marcar o plural masculino:

“ E Elohim criou (h)grandes (h) $\underline{\text { baleias, }}$ e toda alma (h)animal (h)rastejante que (h)águas multiplicaram (l)espécie( $\mathrm{h})$; e toda ave de asas (l)espécie(wh). E Elohim viu que era bom."

Ora, se o sufixo " $\sim$ y" geralmente é formador do masculino plural, então a palavra hebraica traduzida por baleia deverá ser masculina, mesmo porque é definida como termo genérico masculino que no texto bíblico designa grandes animais marinhos ${ }^{1}$. Isso torna evidente sua dupla função, pois além de indicar número (plural), indica também gênero (masculino), o que nos leva a concluir que esta partícula é a forma que indica a flexão de gênero masculino e o número simultaneamente.

A multiplicidade de funções exercidas pelas partículas afixas não denota uma complexidade lexical, ao contrário, aponta para uma simplicidade lingüística e provoca a interação entre estas marcas lingüísticas, que compõem a superfície do texto com os processos cognitivos, psicológicos e sócios-culturais dos usuários.

O prefixo "l" é a forma equivalente à nossa preposição "para", mas, segundo Hollenberg (1991), também é o sinal do dativo em relação ao sujeito - exemplo: $\sim$ hl bhz = eles tem ouro -, a preposição "de" ao parafrasear o genitivo - exemplo: $\mathrm{dwdl} \mathrm{rmzm}=\mathrm{um}$

\footnotetext{
${ }^{1}$ Qatal é a denominação apresentada por Joüon (1993: 359) para a forma verbal conclusa (perfeito).

${ }^{2}$ Neste caso, serão diferenciados por sua forma fonológica(sonora), portanto, na escrita, dependerá do contexto.
} 
salmo de David -, bem como o elemento morfológico formador do infinitivo construto ou o gerúndio - exemplo: rmal = dizer/dizendo -, e o de adjunto adverbial, como é o caso desse texto, cuja tradução para o português pode ser entendida pela palavra conforme.

Alguns afixos hebraicos podem ser traduzidos com diferentes significados em um mesmo texto, como observamos nos exemplos sobre o prefixo "l". Essa diversidade de significados se relaciona diretamente à liberdade que a gramática hebraica lhe confere dentro da sua cultura, permitindo-nos melhor ajuste ao texto na nossa própria cultura sem a necessidade de conhecer profundamente a sintaxe hebraica, isso porque estamos observando o texto em sua forma superficial, na tentativa de manter sua coesão.

"E Elohim criou (h)grandes (h)baleias, e toda alma (h)animal (h)rastejante que (h)águas multiplicaram conforme espécie( $\sim \mathrm{h})$; e toda ave de asas conforme espécie(Wh). E Elohim viu que era bom."

A coerência é o processamento cognitivo do texto, que depende, em muito, da "interpretação" que o receptor/leitor lhe dará, ou seja, do seu conhecimento pessoal. A coesão, por sua vez, utiliza mecanismos de referência para encadear o texto e, portanto, sua dependência do receptor para uma interpretação será bem menor, exigindo apenas a decodificação da disposição destes mecanismos na superfície textual.

Quando um componente desta superfície textual fizer remissão a outro elemento do universo textual ocorrerá a coesão referencial apoiada nas formas remissivas referenciais ${ }^{2}$, ou seja, aquelas que fazem, além da conexão textual, referência a algo no mundo extralingüístico e serão representadas por elementos que fornecem indicações no nível da referência, como por exemplo: Pedro morreu, o amigo de Paulo era tão bom. Será apoiada também nas formas não referenciais, ou seja, naquelas que fazem apenas conexão entre componentes da superfície do texto, representadas por artigos, pronomes adjetivos (demonstrativos, possessivos, indefinidos, interrogativos) e pronomes substantivos (com função pronominal), numerais

\footnotetext{
${ }^{1}$ Segundo Berenzin (1995).

${ }^{2}$ Conforme Koch (1991).
} 
cardinais e ordinais (quando acompanhados de nomes), além dos pronomes pessoais e alguns advérbios pronominais, utilizados para fazer a coesão do texto. Por exemplo: Pedro morreu, ele era tão bom.

Os sufixos " h" e "wh", denominados por Hollenberg (1991) como pronomes pessoais sufixos, por serem formas drásticas reduzidas destes, aparecerão nos textos hebraicos com função pronominal bem mais abrangente, podendo assumir também a função de pronomes oblíquos e possessivos. O sufixo "W" representará a forma da terceira pessoa do singular do gênero masculino ele e o sufixo “ ", sua forma plural eles. O "h", apesar de ser parte integrante do sufixo, se apresenta apenas como um elo comum entre as formas da terceira pessoa.

Novamente, temos uma mesma forma sufixa para representar mais de uma função sintática: os pronomes pessoais sufixos, os pronomes oblíquos e os pronomes possessivos. Isso talvez ocorra em virtude da tendência simplificadora do uso da língua, porém, de qualquer maneira, toda esta diversidade funcional morfológica atende a uma função textual.

\section{Voltemos ao texto:}

"E Elohim criou (h)grandes (h)baleias, e toda alma (h)animal (h)rastejante que (h)águas multiplicaram conforme suas espécies; e toda ave de asas conforme sua espécie. E Elohim viu que era bom.”

Aparentemente, o que restou a ser analisado se auto-explica na própria leitura do texto, portanto, está claro que a função morfológica do "h" é o artigo. Mas convém lembrar que, tanto na língua portuguesa quanto na língua hebraica, o artigo responde pela superfície textual, diferenciando apenas no fato do artigo hebraico ser permeável, ou seja, concorda com o termo prefixado quanto ao número e gênero, o que não acontece na língua portuguesa. No hebraico, uma das suas principais funções como artigo é a obrigatoriedade de prefixar o 
adjetivo quanto ao uso atributivo, ou seja, quando caracterizar o substantivo. (NETO, 1997). Nesse caso, a forma hebraica exige que os dois termos sejam prefixados com o artigo, por exemplo, tXmrh hyxh $=$ o animal rastejante (note que, no segundo termo, temos uma forma participial usada para caracterizar o substantivo, ou seja, como adjetivo atributivo). Além disso, o artigo pode ainda aparecer entre dois substantivos relacionados e, neste caso, ocorre a relação de genitivo em que se subentende a presença da preposição de, que pode ser definida com o artigo prefixando apenas o segundo termo. (HOLLENBERG, 1991). Neste caso a forma será representada conforme o exemplo: hyxh Xpn-lk = toda alma do animal.

Pudemos, assim, observar nesta pequena análise a função dos afixos, a partir da qual se conclui a expressiva importância desta na coesão do texto hebraico, e, finalmente, poderemos ler o texto conforme apresentado no início desta exposição: coerente e coeso.

"E Elohim criou as grandes baleias e toda alma do animal rastejante que as águas multiplicaram conforme suas espécies; e toda ave de asas conforme sua espécie. E Elohim viu que era bom."

\subsection{Uma Didática Para o Aprendizado Dos Sufixos Hebraicos}

Podemos notar a teoria de Piaget, o construtivismo, em ação, uma vez que, para estudarmos os pronomes, criamos uma hipótese e, a partir dela, os relacionamos com seus correspondentes na língua hebraica. Logo após, tratamo-los em sua forma usual na escrita, ou seja, como sufixos, sua forma abreviada. Agora, pretendemos agrupá-los em um gráfico para facilitar sua visualização e compreensão. Estamos, na realidade, construindo hipóteses sucessivas, construindo nosso conhecimento a respeito do hebraico como língua estrangeira.

Expor simplesmente esses sufixos em um gráfico interromperia a idéia construtivista, portanto, para mantê-la precisaremos fortalecer a nossa base real. O conhecimento dos pronomes da língua portuguesa tem sido nossa base real para apoiar a construção do nosso conhecimento sobre os sufixos hebraicos que assumem diversos significados, os quais dependem da interiorização destes sufixos. 
Esta dependência da gramática, tanto da língua de comparação (português) como da língua alvo (hebraico), direciona-nos a focar o aprendizado na forma, pois não poderíamos propor uma tabela contrastiva sem saber a carga semântica que carrega cada sufixo durante sua utilização, nas suas respectivas línguas, visto que os significados desses elementos nos ajudarão a processar o conteúdo de um determinado texto. Tal idéia concorda com Ortega:

...el tipo de instrucción ideal es uno que induzca al aprendiz a dirigir su atención hacia la forma cuando ésta es el vehículo esencial a través del cual el contenido está expresado. ${ }^{1}$

(Ortega, 2001)

Dessa forma, a proposta de ensino utiliza o quadro contrastivo pretendendo facilitar a interiorização dos sufixos de origem pronominal, cuja forma se repetirá, na maioria das vezes, em que a língua e o texto necessitarem da presença desse pronome, para garantir a coesão.

Veja a distribuição desses pronomes nos quadros abaixo:

Tabela 7 Quadro de Recurso Mnemônico Para os Pronomes Hebraicos MASCULINO:

\begin{tabular}{|c|c|c|c|c|}
\hline \multirow{2}{*}{\multicolumn{2}{|c|}{ PRONOMES PESSOAIS }} & \multicolumn{3}{|c|}{ SUFIXOS } \\
\hline & & \multirow{2}{*}{ Verbais $1 \nabla$} & \multicolumn{2}{|c|}{ Pronominais } \\
\hline Português & Hebraico & & Oblíquo $2 \nabla$ & Posse $3 \nabla$ \\
\hline $\mathrm{Eu}$ & $\begin{array}{r}\text { ykinoa }] / y \\
n \text { ia }]\end{array}$ & ytiRaiz & YRaiz & YRaiz \\
\hline $\mathrm{Tu}$ & hT'a; & $T^{\prime}$ Raiz & $\wedge_{\text {Raiz }}$ & $\wedge_{\text {Raiz }}$ \\
\hline Ele & $\mathrm{aWh}$ & Raiz & WRaiz & WRaiz \\
\hline Nós & Wnx.n'a] & WnRaiz & WnRaiz & WnRaiz \\
\hline Vós & $\sim \mathrm{T}, \mathrm{a}$ & $\sim$ t, Raiz & $\sim \mathrm{K}$, Raiz & $\sim$ K,Raiz \\
\hline Eles & $\sim \mathrm{h}$ & Wraiz & $(\sim) \sim \mathrm{h}$, Raiz & $(\sim) \sim \mathrm{h}$, Raiz \\
\hline & $1=$ & a,nada,nu,tem, ${ }^{1}$ & \multicolumn{2}{|c|}{2 e $3=$ iy,kha,o,nu,khem, hem $^{1}$} \\
\hline
\end{tabular}

\section{FEMININO:}

\footnotetext{
${ }^{1}$ Tradução livre: O tipo de instrução ideal é aquele que induz o aprendiz a dirigir sua atenção diante da forma, quando essa é o veículo essencial através do qual o conteúdo é expresso.
} 


\begin{tabular}{|c|c|c|c|c|}
\hline \multirow{2}{*}{\multicolumn{2}{|c|}{ PRONOMES PESSOAIS }} & \multicolumn{3}{|c|}{ SUFIXOS } \\
\hline & & \multirow[b]{2}{*}{ Verbais $1 \nabla$} & \multicolumn{2}{|c|}{ Pronominais } \\
\hline Português & Hebraico & & Oblíquo $2 \boldsymbol{\nabla}$ & Posse $3 \boldsymbol{\nabla}$ \\
\hline $\mathrm{Eu}$ & $\begin{array}{r}\text { ykinoa'/y } \\
\text { n ia] }\end{array}$ & ytiRaiz & YRaiz & YRaiz \\
\hline $\mathrm{Tu}$ & T.a] & T.Raiz & $\%$ Raiz & \%Raiz \\
\hline Ele & ayhi & H 'Raiz & H 'Raiz & H 'Raiz \\
\hline Nós & Wnx.n;a] & WnRaiz & WnRaiz & WnRaiz \\
\hline Vós & (hn')!t,a; & !t,Raiz & !k,Raiz & !k, Raiz \\
\hline Eles & $\left(\mathrm{hn}^{\prime}\right) ! \mathrm{h}$ & Wraiz & (!)!h,Raiz & (!)!h,Raiz \\
\hline ,a,nu,ten & 1 & $=$ & 2 e $3=$ & ,nu,khen,hen ${ }^{1}$ \\
\hline
\end{tabular}

Para os demais sufixos que, passamos a denominar por sufixos nominais com a finalidade de diferenciá-los dos já apresentados, ficamos impossibilitados de utilizar a mesma técnica de aprendizado, porque não podemos relacioná-los aos pronomes pessoais.

Apesar disso, existe forte assimilação dos seus significados quando relacionados aos da língua portuguesa, principalmente quanto à sua utilização. Conforme pudemos observar na exposição apresentada no capítulo anterior são forma indicativa dos morfemas de gênero e número da língua hebraica em sua grande maioria. Tais formas são bem definidas por seus correspondentes conhecidos pelos falantes da língua portuguesa, conforme podemos observar no gráfico abaixo, que facilita a busca dos seus significados:

Tabela 8 Quadro de Sufixos Nominais do Hebraico ${ }^{2}$

\begin{tabular}{|c|c|c|}
\hline \multirow{3}{*}{$\begin{array}{l}\text { Gênero } \\
\text { Masculino }\end{array}$} & Singular & Plural \\
\hline & Raiz & (também indica pares) \\
\hline & & $\sim$ YRaiz \\
\hline
\end{tabular}

\footnotetext{
${ }^{1}$ Recurso mnemônico.

${ }^{2}$ Os aformativos indicativos de procedência (masculino "yRaiz" e feminino "ytRaiz"); de advérbios (" Raiz"); de novos significados nominais ("!WRaiz"/"! Raiz"); de sentidos coletivos ("lRaiz") e de substantivos abstratos ("tRaiz") foram excluídos, porque representam novos verbetes, cujos significados aparecem nos dicionários, podendo, inclusive, receber novos afixos, portanto não justificam sua presença.
} 


\begin{tabular}{|l|r|r|}
\hline Forma Construta $^{1}$ & Raiz & YRaiz \\
\hline Possessivo para $3^{\text {a }}$ Pessoa & & WyRaiz \\
\hline Feminino & hRaiz & tWRaiz \\
\hline Imperativo enfático & hRaiz & hnRaiz \\
\hline Forma Construta & tRaiz & tWRaiz \\
\hline Pares & & ytRaiz \\
\hline Possessivo para $3^{\text {a }}$ Pessoa & h & hyRaiz \\
\hline Locativo & h & \\
\hline
\end{tabular}

\subsection{Uma Didática Para o Aprendizado Dos Prefixos Hebraicos}

Embora sabendo que a nomenclatura "prefixo pronominal no verbo" não seja de uso corrente, em virtude da preferência para preformativo verbal, entendemos que esses elementos podem ser considerados prefixos pronominais no verbo e devem ser assimilados da mesma maneira que os sufixos verbais. Por esse motivo, utilizaremos a mesma técnica para a assimilação desses prefixos, ou seja, por meio de um quadro contrastivo, já que a identificação pretendida permanece no campo visual do texto.

Observe abaixo os quadros contrastivos dos prefixos pronominais:

\footnotetext{
${ }^{1}$ Veja a explicação na página 44, nota 03.
} 
4.3.1. Tabela 9 Quadro de Recurso Mnemônico Para os Pronomes Prefixos do Hebraico: 4.3.1.1. MASCULINO:

\begin{tabular}{|c|c|c|c|}
\hline \multicolumn{2}{|c|}{ PRONOMES PESSOAIS } & \multicolumn{2}{|c|}{ FORMAS VERBAIS } \\
\hline Português & Hebraico & Inconclusa & Prefixo $1 \boldsymbol{\nabla}$ \\
\hline $\mathrm{Eu}$ & $\begin{array}{r}\text { ykinoa }] / y \\
n \text { ia }]\end{array}$ & Raiza & $\mathrm{a}$ \\
\hline $\mathrm{Tu}$ & hT'a; & RaizT & $\mathrm{T}$ \\
\hline Ele & $\mathrm{aWh}$ & Raiz y & $\mathrm{y}$ \\
\hline Nós & Wnx.n'a] & Raiz $\mathrm{n}$ & $\mathrm{n}$ \\
\hline Vós & $\sim \mathrm{T}, \mathrm{a}$ & Wraiz T & $\mathrm{T}$ \\
\hline Eles & $\sim \mathrm{h}$ & Wraiz y & $\mathrm{y}$ \\
\hline \multicolumn{2}{|c|}{ Recurso mnemônico } & $1=\mathrm{a}$, & ta,y,nun,ta,y \\
\hline
\end{tabular}

\subsubsection{FEMININO:}

\begin{tabular}{|c|c|c|c|}
\hline \multicolumn{2}{|c|}{ PRONOMES PESSOAIS } & \multicolumn{2}{|c|}{ FORMAS VERBAIS } \\
\hline Português & Hebraico & Inconclusa & Prefixo $2 \nabla$ \\
\hline $\mathrm{Eu}$ & $\begin{array}{r}\text { ykinoa]/y } \\
\text { n ia] }\end{array}$ & Raiza & a \\
\hline $\mathrm{Tu}$ & hT'a; & RaizT & $\mathrm{T}$ \\
\hline Ele & $\mathrm{aWh}$ & RaizT & $\mathrm{T}$ \\
\hline Nós & Wnx.n'a] & Raiz $\mathrm{n}$ & $\mathrm{n}$ \\
\hline Vós & $\sim \mathrm{T}, \mathrm{a}$ & hnRaizT & $\mathrm{T}$ \\
\hline Eles & $\sim \mathrm{h}$ & hnRaizT & $\mathrm{T}$ \\
\hline \multicolumn{2}{|c|}{ Recurso mnemônico } & \multicolumn{2}{|c|}{$2=\mathrm{e}, \mathrm{te}, \mathrm{te}, \mathrm{ne}, \mathrm{te}, \mathrm{te}$} \\
\hline
\end{tabular}

4.3.2. Tabela 10 Quadro de Recurso Mnemônico Para os Prefixos Nominais do Hebraico:

\begin{tabular}{|l|c|}
\hline \multicolumn{1}{|c|}{ Significados $^{1}$} & Prefixos $^{-}$ \\
\hline E, mas, então & \\
\hline
\end{tabular}

${ }^{1}$ Conforme, Berezzin (1995: 201, 39, 285, 311, 327, 615, 103), respectivamente.

${ }^{2}$ Embora o quadro tenha sido elaborado para nomes, não devemos esquecer que o Waw é prefixo formador das conjugações Wayyiqtol e Weqatal. 


\begin{tabular}{|l|c|}
\hline Em, entre, com, por, através & Raiz b \\
\hline Como, aproximadamente, mais ou menos, de acordo com, durante, quando & Raiz $\mathbf{k}$ \\
\hline Para, para o, para a, para os, para as & Raiz 1 \\
\hline De, desde, do que & Raiz $\mathbf{m}$ \\
\hline Que, porque, isto & Raiz X \\
\hline O, a, os, as - prefixo utilizado como artigo definido ou interrogativo & Raiz \\
\hline
\end{tabular}

Recurso mnemônico $\mathrm{hXmlkbw}=$ uvequelemescheh

\subsubsection{Sistematizando o Quadro Contrastivo dos Afixos Hebraico}

O léxico dos pronomes da língua portuguesa apresentado no início deste capítulo, se não fizer parte do vocabulário (ativo ou passivo) do aprendiz brasileiro da língua estrangeira hebraico, far-lo-á de seu conjunto lexical virtual e do universo léxico de sua língua materna.

A forma pronominal hebraica também observada neste capítulo apresentou-se como ponto de partida para a conjugação verbal. Foi utilizando os pronomes pessoais abreviados como prefixos e/ou como sufixos de "conjugação" que se construiu a "conjugação" do verbo hebraico e, da mesma maneira, se chegou aos sufixos pronominais representantes dos pronomes oblíquos e possessivos.

O léxico dos demais afixos hebraicos, apresentados como prefixos e/ou sufixos nominais nesse capítulo, somado às formas pronominais observadas constitui um corpo significativo de elementos formadores da linearidade da superfície textual do hebraico. Isso nos garante um número limitado destes elementos, que podem ser utilizados na construção de um número ilimitado de textos.

O conhecimento lexical desses elementos da língua portuguesa pode ser associado ao vocabulário ou ao conjunto lexical virtual do aprendiz brasileiro de língua hebraica, para nele produzir o conhecimento da grande maioria dos lexemas pronominais do hebraico, assim como de várias preposições e de alguns importantes significados da sintaxe hebraica, demonstrando, desta forma, que o léxico da língua materna pode ser utilizado como alavanca para a aquisição do léxico hebraico. 
"desde", como "sem" / 1 como formador do infinitivo, como formador do gerúndio, como "de", / O W com verbo, no início de oração, para marcar a narrativa em 3 pessoa do passado (em conjugações inconclusas) e futuro (em conjugações conclusas).

\subsection{Relato de Aplicação da Proposta de Ensino - O Caso Marlene}

O sujeito desta investigação não havia recebido outro aprendizado além da alfabetização hebraica quando lhe foi submetido o quadro apresentado no final do capítulo anterior, portanto, admitimos como único conhecimento de Marlene sua alfabetização.

De posse deste instrumento de trabalho, estranho em seu primeiro contato, Marlene não poderia executar nenhuma tarefa sem que recebesse alguns conceitos básicos iniciais e, como primeiro passo, ela foi informada sobre sua finalidade e forma de aplicação.

Aprende agora que as palavras hebraicas são formadas, basicamente, por três consoantes radicais, apesar de existirem palavras com menos ou mais consoantes radicais, porém, numa ocorrência bem menor, mas quando aplicadas em um texto qualquer, receberão afixos para construírem a conexão textual.

Em seguida, foram apresentados a ela os afixos como elementos básicos para poder trabalhar com o quadro resumo e um bom dicionário.

É importante esclarecer que não houve investigações comparativas, analisamos apenas um sujeito, sem focarmos o tempo de aprendizado, visto que a intenção deste relato é apontar para a viabilidade do método quanto à sua aplicação. $\mathrm{O}$ sujeito da investigação, após poucos encontros, era capaz de realizar boas traduções. 


\section{CONCLUSÃO}

A pesquisa procurou demonstrar o papel dos afixos hebraicos no ensino/ aprendizagem da língua na contemplação do iniciante de leitura e no seu entendimento textual do ponto de vista do aprendiz limitado ao campo visual.

Não obstante, dado a afirmação de que o hebraico é uma língua de difícil aprendizado, foi necessário desfazer tal pressuposto com a finalidade de se estabelecer um ponto de partida fortalecido nas idéias desenvolvidas das teorias sobre ensino/aprendizagem.

A base da afirmação fundamentou-se na idéia da existência de três tipos de hebraicos diferentes: o bíblico, o talmúdico e o moderno. Uma vez demonstrado que estes não passavam de três períodos distintos de uma mesma língua, foi possível escolher um caminho que pudesse esclarecer a maneira pela qual um aprendiz pode alcançar a aquisição da língua.

A pesquisa apresentou como uma das barreiras iniciais no aprendizado de hebraico sua peculariedade na escrita por meio de símbolos, incomum nas escritas latinas, bem como na sua forma sinistrógrada de escrita. Por isso, foi utilizado como ponto de partida do ensino esta forma visual, vislumbrando um efeito oposto, ou seja, o aprendizado no aspecto visual do texto escrito.

O campo visual seria muito restritivo para o aprendizado de uma segunda língua, assim, a pesquisa se estendeu para o campo da lingüística textual em busca de um método que apresentasse elementos chaves da língua com flexibilidade suficiente e possibilidade de serem reutilizados em vários contextos. Foi a repetição de consoantes iniciais/finais idênticas em palavras nos diferentes contextos da língua hebraica que chamou a atenção para os afixos 
consonantais. Uma investigação textual apresentada na pesquisa tornou isso claro. Essas consoantes não apenas formam um conjunto de afixos distintos, isto é, com significados diversos, mas, além disso, responsabilizam-se pela coesão do texto, ou seja, pela conexão textual.

Neste caso, a pesquisa caminhou para a lingüística descritiva, estabelecendo os elementos de coesão do texto hebraico a partir dos seus afixos como elementos visuais capazes de promover a iniciação da aquisição do hebraico língua estrangeira.

As consoantes afixas são em número limitado no hebraico e correspondem aos pronomes da língua portuguesa em grande quantidade, além de conjunções e preposições. Nesse sentido, uma análise comparativa desses pronomes possibilitou a apresentação de uma tabela geral contrastiva, que pode ser uma boa ferramenta de ensino na iniciação do aprendizado do hebraico língua estrangeira para brasileiros. Defendemos que tal aprendizado deverá ser obtido através do ensino com foco na forma, uma vez que está baseado na sua gramática, conforme demonstrado no capítulo quatro, cuja abordagem propôs uma metodologia de ensino e compreensão do texto hebraico.

A apresentação do tema teve como ponto de partida a idéia de Piaget, pois contempla a construção de um conhecimento amplo a partir dos pronomes pessoais para chegar aos oblíquos na forma sufixal e demais afixos apresentados na pesquisa. As didáticas apresentadas para facilitar o aprendizado e o caso Marlene utilizado como exemplo pressupõem a interação do aprendiz com o professor ou com o texto e aponta para sua possível aplicabilidade. 


\section{BIBLIOGRAFIA}

ALMEIDA FILHO, J.C.P. Parametros atuais para o ensino de português língua

Estrangeira. Campinas: Pontes, 1997

ALMEIDA, J.F. A Bíblia sagrada. 39. ed. Rio de Janeiro: Imprensa Bíblica Brasileira, 1977.

ALLWRIGTH, D. The death of the method. Plenary paper for the SGAV Conference.

Ottawa(Canadá): Calerton University, 1991.

ANTHONY, E.M. Approach, Method and Thecnique. English Language Teaching (17), 1963.

BASÍLIO, M. Teoria lexical. Série Princípios, 2. ed. São Paulo: Ática, 1989.

BEREZIN, J. R. Dicionário Hebraico-Português. São Paulo: EDUSP, 1995.

BROWN, F.; DRIVER, S.R.; BRIGGS,C.A. The Brown-Driver-Briggs and English

Lexicon: Whith an Appendix Containing the Biblical Aramaic. Massachusetts(USA) :

Hendrickison Publishers Inc., 1996.

CHOMSKY, N. Aspects of the Theory of Syntax. Cambridge: MIT Press, 1965.

FERREIRA, A. B. H. Mini Aurélio - Século XXI. Rio de Janeiro(RJ): Nova Fronteira, 2001.

FREEMAN, D. L. \& LONG, M. H. Introducción al Estudio de la adquisición de Segundas

Lenguas. Versão Espanhola Isabel Molina Martos \& Pedro Benítez Pérez. Madrid : Gredos, 1994.

GREIMAS, A.J. \& COURTÉS, J. Dicionário de Semiótica. São Paulo: Cultrix, 1979.

HADAS-LEBEL, M. O Hebraico:3000 Anos de História. Tradução Eliana Branco Malanga.

São Paulo, Centro de Estudos Judaicos FFLCH USP, 1998.

HARRIS, R. L.;ARCHER JR, G. L.; WALTKE, B. K. Dicionário Internacional de Teologia do Antigo Testamento. Tradução Márcio Loureiro Redondo; Luiz A.T.Sayão; Carlos Osvaldo C. Pinto. São Paulo: Vida Nova, 1998.

HOOKER, J.T. (Introdutor) Lendo o Passado: Do Cuneiforme ao Alfabeto. A História da Escrita Antiga São Paulo - Edusp, 1996.

HOLlENBERG, J. \& BUDDE, K. Gramática Elementar da Língua Hebraica. Tradução de Nelson Kirst. $7^{a}$ ed. São Leopoldo(R.S.): Editora Sinodal, 1991.

HÜBNER, M.M. Guia para elaboração de monografias e projetos de dissertação de mestrado e doutorado. São Paulo: Mackenzie, 2002.

JOÜAN, P. \& Muraoka, T. A grammar of biblical hebrew. Roma: PIB, 1993. 
KOCH, I. G. V. A Coesão textual. 4. ed. São Paulo: Contexto, 1991.

KELLEY, P. H. Hebraico Bíblico: uma gramática introdutória. Rio Gde do Sul: Sinodal, 1998.

KRASHEN, S. D. Principles and practice in second language acquisition. New York: Pergamon Institute of English, 1982.

LIMA, M. S. Aquisição de L2/LE e o insumo instrucional na sala de aula. In: Daniela D. Araújo e Luciane Sturm. Século XXI: Um novo olhar sobre o ensino e a aprendizagem de línguas estrangeiras. Passo Fundo(RGS): UPF Editora, 2002.

LUFT, C. P. Minidicionário Luft. 20ª .Edição, 9a .Impressão. São Paulo: Ática, 2002.

MAROTE, J. T. d'Olim. O Ensino do Léxico em Língua Materna e Estrangeira. Revista Brasileira de Lingüística. São Paulo, v. 08, n. 1, p. - . 08, Ago 1995.

MARTINET, A. Função e Dinâmica das Línguas. Tradução Jorge de Moraes Barbosa e Maria Joana Vieira Santos. Coimbra(Portugal): Livraria Almedina, 1995.

MELAMED, R. M. M. A Lei de Moisés e as "Haftarot". 4" ed. Rio de Janeiro: Danúbio, 1980.

MULLER, C. Estadística Linguística. Madrid(Espanha): Gredos, 1973.

NETO, P. C. \& INFANTE, U. Gramática da Língua Portuguesa. São Paulo(SP): Scipione, 1997.

ORTEGA, L. Atención implícita hacia la forma: teoria e investigación. In: Eds. SUSANA PASTOR CESTEROS y VENTURA SALAZAR GARCIA. Anexo I de Estúdios de Lingüística da Universidad de Alicante: Tendências y líneas de investigación em adquisición de segundas lenguas. Alicante, 2001.

PALOMO, S. M. S. O Ensino de Línguas Estrangeiras: O Léxico. Revista Ciência e Cultura. São Paulo, v. 40, n. 07 - Suplemento ISSN 0102 - 2474, 1988.

PRABHU, N.P. There is no Best Method - Why? Tesol Quarterly, v. 24, n. 2., 1990.

REVUZ, C. A Língua estrangeira entre o desejo de um outro lugar e o risco do exílio. In Org. INÊS SIGNORINE. Lingua(gem) e Identidade: elementos para uma discussão no campo aplicado. São Paulo: Mercado de Letras, 1998.

RABIN, C. Pequena História da Língua Hebraica. Tradução Rifka Berenzin. São Paulo: Summus Editorial, 1973.

ROTH, C. Enciclopédia Judaica. Rio de Janeiro: Tradição, 1967. 
SÁENZ-BADILLOS, A. A History of the Hebrew Language. Cambridge: Cambridge University Press, 1997.

SANTOS, R. S. A aquisição da Linguagem. In: Org. JOSÉ LUIZ FIORIN. Introdução à Lingüística. São Paulo: Contexto, 2002.

SCARPA, E. M. Aquisição da Linguagem. In: Orgs. FERNANDA MUSSALIM; ANNA

CHRISTINA BENTES. Introdução à Linguística. v. II. São Paulo: Cortez, 2001.

SIMÕES, L. C. Autenticidade e a abordagem comunicativa: reflexões sobre a sala de aula de língua inglesa. 2004. f. Mestrado em Lingua Inglesa. Paraná.

SITYA, C. V. M. A linguística textual e a análise do discurso: uma abordagem interdisciplinar. Frederico Westphalen(RS): URI, 1995.

VILELA, M. Estruturas Léxicas do Português. Coimbra: Almeidinha, 1979.

YEIVIN, I. Introduction to the Tiberian Masorah. Masoretic Studies 5. Missoula: Scholars Press, 1980. 